Prepared in cooperation with the Great Lakes Restoration Initiative

\title{
Climate, Streamflow, and Lake-Level Trends in the Great Lakes Basin of the United States and Canada, Water Years 1960-2015
}

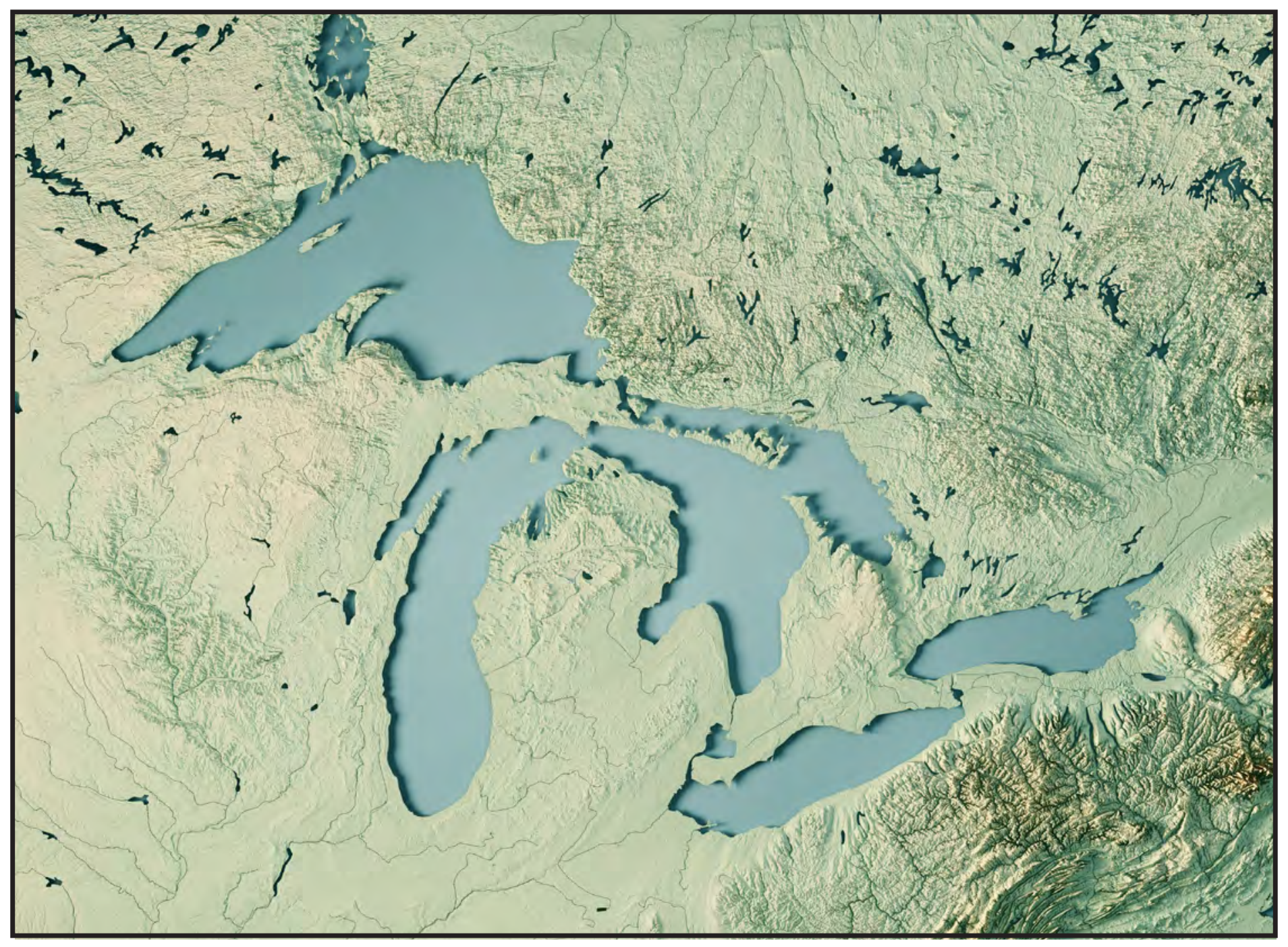

Scientific Investigations Report 2019-5003 
Cover. Photograph showing Great Lakes 3D rendering topographic map. Copyrighted; used with permission, istockphoto.com 


\section{Climate, Streamflow, and Lake-Level Trends in the Great Lakes Basin of the United States and Canada, Water Years 1960-2015}

By Parker A. Norton, Daniel G. Driscoll, and Janet M. Carter

Prepared in cooperation with the Great Lakes Restoration Initiative

Scientific Investigations Report 2019-5003 


\title{
U.S. Department of the Interior \\ DAVID BERNHARDT, Acting Secretary
}

\author{
U.S. Geological Survey \\ James F. Reilly II, Director
}

U.S. Geological Survey, Reston, Virginia: 2019

For more information on the USGS - the Federal source for science about the Earth, its natural and living resources, natural hazards, and the environment-visit https://www.usgs.gov or call 1-888-ASK-USGS.

For an overview of USGS information products, including maps, imagery, and publications,

visit https://store.usgs.gov.

Any use of trade, firm, or product names is for descriptive purposes only and does not imply endorsement by the U.S. Government.

Although this information product, for the most part, is in the public domain, it also may contain copyrighted materials as noted in the text. Permission to reproduce copyrighted items must be secured from the copyright owner.

Suggested citation:

Norton, P.A., Driscoll, D.G., and Carter, J.M., 2019, Climate, streamflow, and lake-level trends in the Great Lakes Basin of the United States and Canada, water years 1960-2015: Scientific Investigations Report 2019-5003, 47 p., https://doi.org/10.3133/sir20195003. 


\section{Contents}

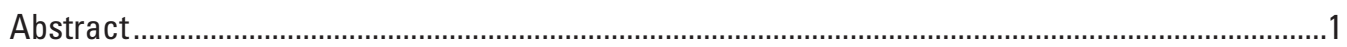

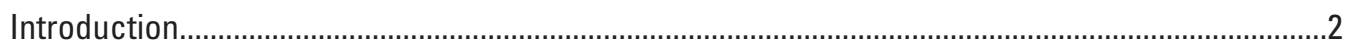

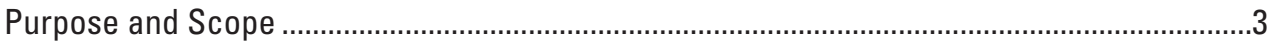

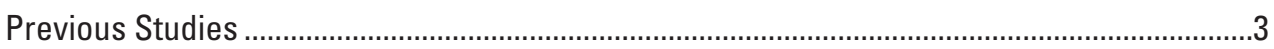

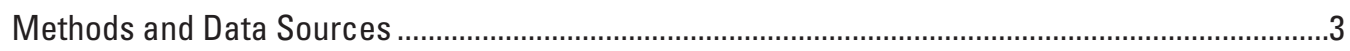

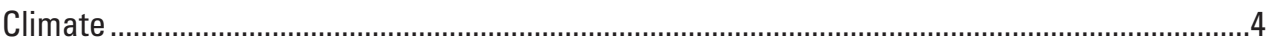

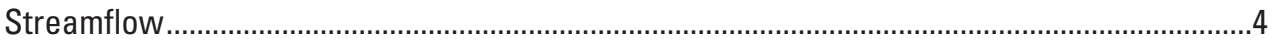

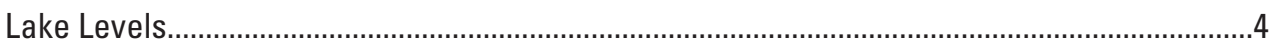

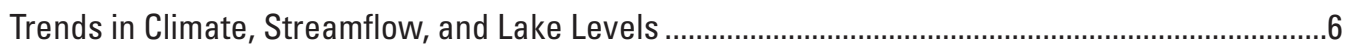

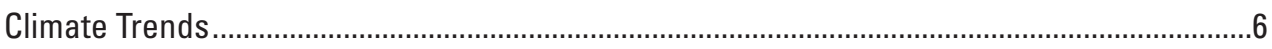

Streamflow Trends

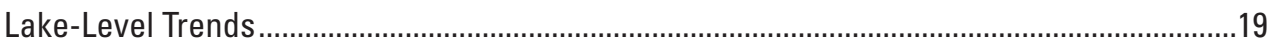

Factors Affecting Lake Levels .......................................................................................19

Information Regarding Water-Budget Components .......................................................19

Trends in Annual Lake Levels and Major Water-Budget Components...........................22

Monthly Lake Levels and Water-Budget Components .................................................28

Additional Perspectives on Lake-Level Trends for Water Years 1960-2015 ...................40

Implications Regarding Serial Correlation in Trend Analyses......................................................41

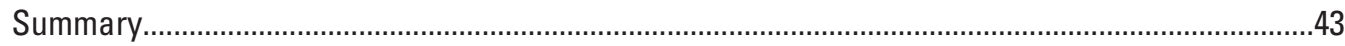

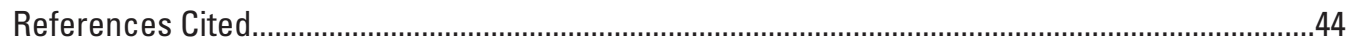

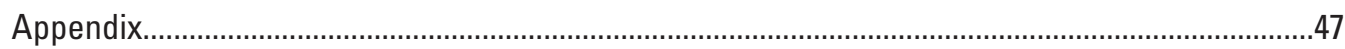

\section{Figures}

1. Map showing the Great Lakes Basin of the United States and Canada ............................2

2. Map showing streamgages in the Great Lakes Basin in the United States and Canada used for streamflow trend analyses, water years 1960-2015 ..............................5

3. Graphs showing trends in climate data for the land part of the Great Lakes Basin in the United States, water years 1960-2015 ...............................................................

4. Graph showing trends in climate data for the land part of the Lake Superior subbasin in the United States, water years 1960-2015 ..................................................8

5. Graph showing trends in climate data for the land part of the Lake Michigan subbasin in the United States, water years 1960-2015 .....................................................

6. Graph showing trends in climate data for the land part of the Lake Huron subbasin in the United States, water years 1960-2015.

7. Graph showing trends in climate data for the land part of the Lake Erie subbasin in the United States, water years 1960-2015

8. Graph showing trends in climate data for the land part of the Lake Ontario subbasin in the United States, water years 1960-2015.

9. Maps showing trends in annual streamflow at streamgages in the Great Lakes Basin with statistically significant annual climate trends for 2.5-arc-minute Parameter-elevation Regressions on Independent Slopes Model grid cells within the United States for water years 1960-2015. 
10. Maps showing seasonal streamflow trends at streamgages in the Great Lakes Basin with statistically significant seasonal climate trends for 2.5-arc-minute Parameter-elevation Regressions on Independent Slopes Model grid cells within the United States for water years 1960-2015.

11. Maps showing seasonal streamflow trends at streamgages in the Great Lakes Basin with statistically significant seasonal climate trends for 2.5-arc-minute Parameter-elevation Regressions on Independent Slopes Model grid cells within the United States for water years 1960-2015.

12. Maps showing seasonal streamflow trends at streamgages in the Great Lakes Basin with statistically significant seasonal climate trends for 2.5-arc-minute Parameter-elevation Regressions on Independent Slopes Model grid cells within the United States for water years 1960-2015.

13. Maps showing seasonal streamflow trends at streamgages in the Great Lakes Basin with statistically significant seasonal climate trends for 2.5-arc-minute Parameter-elevation Regressions on Independent Slopes Model grid cells within the United States for water years 1960-2015.

14. Diagram showing the profile of the Great Lakes System ............................................20

15. Graph showing major water-budget components for the Great Lakes..........................21

16. Graphs showing annual trends in lake level and major water-budget components for Lake Superior, water years 1960-2015.

17. Graphs showing annual trends in lake level and major water-budget components for Lakes Michigan and Huron, water years 1960-2015

18. Graphs showing annual trends in lake level and major water-budget components for Lake Saint Clair, water years 1960-2015.

19. Graphs showing annual trends in lake level and major water-budget components for Lake Erie, water years 1960-2015.

20. Graphs showing annual trends in lake level and major water-budget components for Lake Ontario, water years 1960-2015.

21. Graphs showing trends in major water-budget components for the Great Lakes Basin, water years 1960-2015

22. Graphs showing trends in annual net basin supply for the individual Great Lakes and for the Great Lakes Basin, water years 1960-2015.

23. Graph showing monthly mean lake levels for Lake Superior, water years 1960-2015 ...32

24. Graph showing monthly mean lake levels for Lakes Michigan and Huron, water years 1960-2015

25. Graph showing monthly mean lake levels for Lake Saint Clair, water years 1960-2015.

26. Graph showing monthly mean lake levels for Lake Erie, water years 1960-2015 ...........35

27. Graph showing monthly mean lake levels for Lake Ontario, water years 1960-2015 .....36

28. Bar graph showing the means of monthly overlake precipitation, runoff, overlake evaporation, and net basin supply for Lake Superior, water years 1960-2015 
29. Bar graph showing the means of monthly overlake precipitation, runoff, overlake evaporation, and net basin supply for Lakes Michigan and Huron, water years 1960-2015

30. Bar graph showing the means of monthly overlake precipitation, runoff, overlake evaporation, and net basin supply for Lake Saint Clair, water years 1960-2015

31. Bar graph showing the means of monthly overlake precipitation, runoff, overlake evaporation, and net basin supply for Lake Erie, water years 1960-2015.

32. Bar graph showing the means of monthly overlake precipitation, runoff, overlake evaporation, and net basin supply for Lake Ontario, water years 1960-2015

33. Bar graph showing the means of monthly overlake precipitation, runoff, overlake evaporation, and net basin supply for the Great Lakes Basin, water years 1960-2015..39

1.1 to 1.103. Graphs showing streamflow trends for U.S. Geological Survey streamgages in the Great Lakes Basin for water years 1960-2015. Available online only at https://doi.org/10.3133/sir20195003.

1.104 to 1.138 . Graphs showing streamflow trends for Environment and Climate Change Canada streamgages in the Great Lakes Basin for water years 1960-2015. Available online only at https://doi.org/10.3133/sir20195003.

\section{Tables}

1. Surface areas for Great Lakes and associated drainage basins

2. Mean relative contributions to the Great Lakes Basin outflow and major waterbudget components, by lake, water years 1960-2015

3. Summary of results from comparison of standard and modified Mann-Kendall tests for streamflow data

1.1. Site information and mean streamflow values (annual, seasonal, and monthly) for streamgages in the Great Lakes Basin selected for statistical analyses, water years 1960-2015. Available online only at https://doi.org/10.3133/sir20195003.

1.2. Streamflow trends for annual and seasonal intervals for selected streamgages in the Great Lakes Basin, water years 1960-2015. Available online only at https://doi.org/10.3133/sir20195003.

1.3. Comparison of results from standard and modified Mann-Kendall tests for climate data from the Parameter-elevation Regressions on Independent Slopes Model (PRISM), water years 1960-2015. Available online only at https://doi.org/10.3133/sir20195003.

1.4. Streamflow trends for annual and seasonal intervals for selected streamgages in the Great Lakes Basin, water years 1960-2015. Available online only at https://doi.org/10.3133/sir20195003.

1.5. Comparison of results from standard and modified Mann-Kendall tests for water-budget components, water years 1960-2015. Available online only at https://doi.org/10.3133/sir20195003. 


\section{Conversion Factors}

U.S. customary units to International System of Units

\begin{tabular}{|c|c|c|}
\hline Multiply & By & To obtain \\
\hline \multicolumn{3}{|c|}{ Length } \\
\hline inch (in.) & 2.54 & centimeter $(\mathrm{cm})$ \\
\hline inch (in.) & 25.4 & millimeter (mm) \\
\hline foot (ft) & 0.3048 & meter $(\mathrm{m})$ \\
\hline \multicolumn{3}{|c|}{ Area } \\
\hline square mile $\left(\mathrm{mi}^{2}\right)$ & 2.590 & square kilometer $\left(\mathrm{km}^{2}\right)$ \\
\hline \multicolumn{3}{|c|}{ Flow rate } \\
\hline cubic foot per second $\left(\mathrm{ft}^{3} / \mathrm{s}\right)$ & 0.02832 & cubic meter per second $\left(\mathrm{m}^{3} / \mathrm{s}\right)$ \\
\hline
\end{tabular}

Temperature in degrees Fahrenheit $\left({ }^{\circ} \mathrm{F}\right)$ may be converted to degrees Celsius $\left({ }^{\circ} \mathrm{C}\right)$ as follows:

$$
{ }^{\circ} \mathrm{C}=\left({ }^{\circ} \mathrm{F}-32\right) / 1.8 \text {. }
$$

\section{Datum}

Vertical coordinate information is referenced to the North American Vertical Datum of 1988 (NAVD 88) unless otherwise specified.

Horizontal coordinate information is referenced to the North American Datum of 1983 (NAD 83) unless otherwise specified.

Elevation, as used in this report, refers to distance above the vertical datum.

\section{Supplemental Information}

A water year is the 12-month period from 0ctober 1 through September 30 and is designated by the calendar year in which it ends.

\section{Abbreviations}

$\begin{array}{ll}\text { ECCC } & \text { Environment and Climate Change Canada } \\ \text { LOESS } & \text { locally weighted regression } \\ \text { NBS } & \text { net basin supply } \\ p \text {-value } & \text { probability value from Kendall's tau nonparametric test } \\ \text { PRISM } & \text { Parameter-elevation Regressions on Independent Slopes Model } \\ \text { STP } & \text { short-term persistence } \\ \tau & \text { tau from Kendall's tau nonparametric test } \\ T_{\max } & \text { monthly means of daily maximum air temperature } \\ T_{\min } & \text { monthly means of daily minimum air temperature } \\ \text { USGS } & \text { U.S. Geological Survey } \\ \text { WY } & \text { water year }\end{array}$




\title{
Climate, Streamflow, and Lake-Level Trends in the Great Lakes Basin of the United States and Canada, Water Years 1960-2015
}

\author{
By Parker A. Norton, Daniel G. Driscoll, and Janet M. Carter
}

\section{Abstract}

Water levels in the Great Lakes fluctuate substantially because of complex interactions among inputs (precipitation and streamflow), outputs (evaporation and outflow), and other factors. This report by the U.S. Geological Survey in cooperation with the Great Lakes Restoration Initiative was completed to describe trends in climate, streamflow, lake levels, and major water-budget components within the Great Lakes Basin for water years (WYs) 1960-2015 (study period). Resulting trends are applicable only to the study period and should not be considered indicative of longer-term trends.

Analyses of climate trends used monthly data from the Parameter-elevation Regressions on Independent Slopes Model, which are available only for the United States. Trend tests were completed for annual and seasonal time series of monthly means for total precipitation, daily minimum air temperature $\left(T_{\min }\right)$, and daily maximum air temperature $\left(T_{\max }\right)$. Statistical significance for all time-trend tests (climate, streamflow, and lake levels) was determined using the Mann-Kendall test for probability values less than or equal to 0.10 . Trend analyses were completed without adjustments for serial correlation; however, a modified Mann-Kendall test was subsequently used to examine potential effects of short-term persistence in time-series data. Effects of shortterm persistence were considered inconsequential for climate data and minor for streamflow data; however, the presence of short-term persistence in water-budget components had more substantial effects on trend analyses.

Spatial distributions of trends in climatic data for WYs 1960-2015 for the U.S. part of the Great Lakes Basin (land only) indicate (1) generally ubiquitous upward trends in $T_{\min }$ and (2) a sharp transition from neutral or downward trends in precipitation northwest of Lake Michigan to generally upward trends east of Lake Michigan. Trends in $T_{\max }$ were not statistically significant. Analyses of annual climatic data aggregated for the U.S. land part of the Great Lakes Basin indicated statistically significant upward trends for precipitation and $T_{\min }$, and similar statistically significant trends existed for all the individual lake subbasins except Lake Superior.
Of 103 U.S. Geological Survey streamgages analyzed for streamflow trends, 71 had significant annual trends (54 upward and 17 downward). Downward trends in annual streamflow are concentrated northwest of Lake Michigan (16 streamgages), and upward trends are concentrated east of Lake Michigan (53 streamgages). Of the 71 streamgages with significant annual trends, 70 had at least one season with a significant trend that matched the annual trend direction.

Of 35 Environment and Climate Change Canada streamgages analyzed, 22 had significant upward trends in annual streamflow, and all but 1 of these 22 had at least one season with a significant upward trend. None of the Environment and Climate Change Canada streamgages had significant downward annual trends, and only one had a significant downward seasonal trend.

Trends in lake levels and several major water-budget components affecting lake levels were analyzed for the study period. Significant downward trends in lake level and outflow for Lake Superior are driven primarily by low lake levels and outflows during WYs 1998-2014. A significant downward trend in runoff from the contributing drainage area also is indicated, which is consistent with numerous streamgages northwest of Lake Michigan with significant downward trends in annual streamflow. A significant upward trend in annual overlake evaporation also is indicated, which is consistent with the spatially distributed upward trends in annual $T_{m i n}$.

The sum of overlake precipitation and runoff from the contributing drainage area for each of the Great Lakes, less overlake evaporation, composes a variable called net basin supply (NBS). A significant downward trend in NBS is indicated for Lake Superior, which is consistent with significant trends for individual components of runoff (downward) and evaporation (upward) that contributed to a significant downward trend for lake outflow. Statistically significant upward trends in NBS for Lake Saint Clair and Lake Ontario offset the downward trend for Lake Superior and combine with nonsignificant upward trends in NBS for Lakes Michigan and Huron and Lake Erie to produce a neutral trend in NBS for the basin. 
A predictable pattern in monthly mean lake levels is noted for Lake Superior, with the minimum for each year usually during or near March and the maximum commonly during or near September or October. When an October lake level is in a period of substantial decline, potential for an ensuing short-term period of below-mean lake levels is enhanced. Downstream from Lake Superior, monthly lake levels have sawtooth patterns that somewhat resemble those for Lake Superior but with decreased predictability in timing.

Similar to Lake Superior, Lakes Michigan and Huron, Lake Saint Clair, and Lake Erie all have a prolonged period of low lake levels around WYs 1998-2014; however, a significant downward trend is indicated only for Lakes Michigan and Huron. All these lakes also have a period of low lake levels before about WY 1968, when minimum lake levels were lower than during WYs 1998-2014. The significant downward trend of outflow from Lake Superior is carried downstream into Lakes Michigan and Huron; however, trends in outflow from the next three lakes downstream (Lakes Saint Clair, Erie, and Ontario) are offset by increased precipitation and runoff and are not significant.

\section{Introduction}

The Great Lakes of North America (Lakes Superior, Michigan, Huron, Erie, and Ontario; fig. 1) are the largest group of freshwater lakes on Earth and account for about 24 percent of the world's reserves of freshwater in lakes (Shiklomanov, 1993). By surface area, Lake Superior is the largest freshwater lake in the world (Shiklomanov, 1993). The Great Lakes cover an area of about 95,000 square miles $\left(\mathrm{mi}^{2}\right)$, and their combined drainage basins include an area of about 200,000 $\mathrm{mi}^{2}$ in the United States and Canada (Hunter and others, 2015; fig. 1). The Great Lakes are an important source of drinking water, transportation, power, and recreational opportunities for the United States and Canada. The Great Lakes also support abundant commercial and recreational fisheries, are crucial for agriculture, and are essential to the economic vitality of the region (U.S. Geological Survey, 2014).

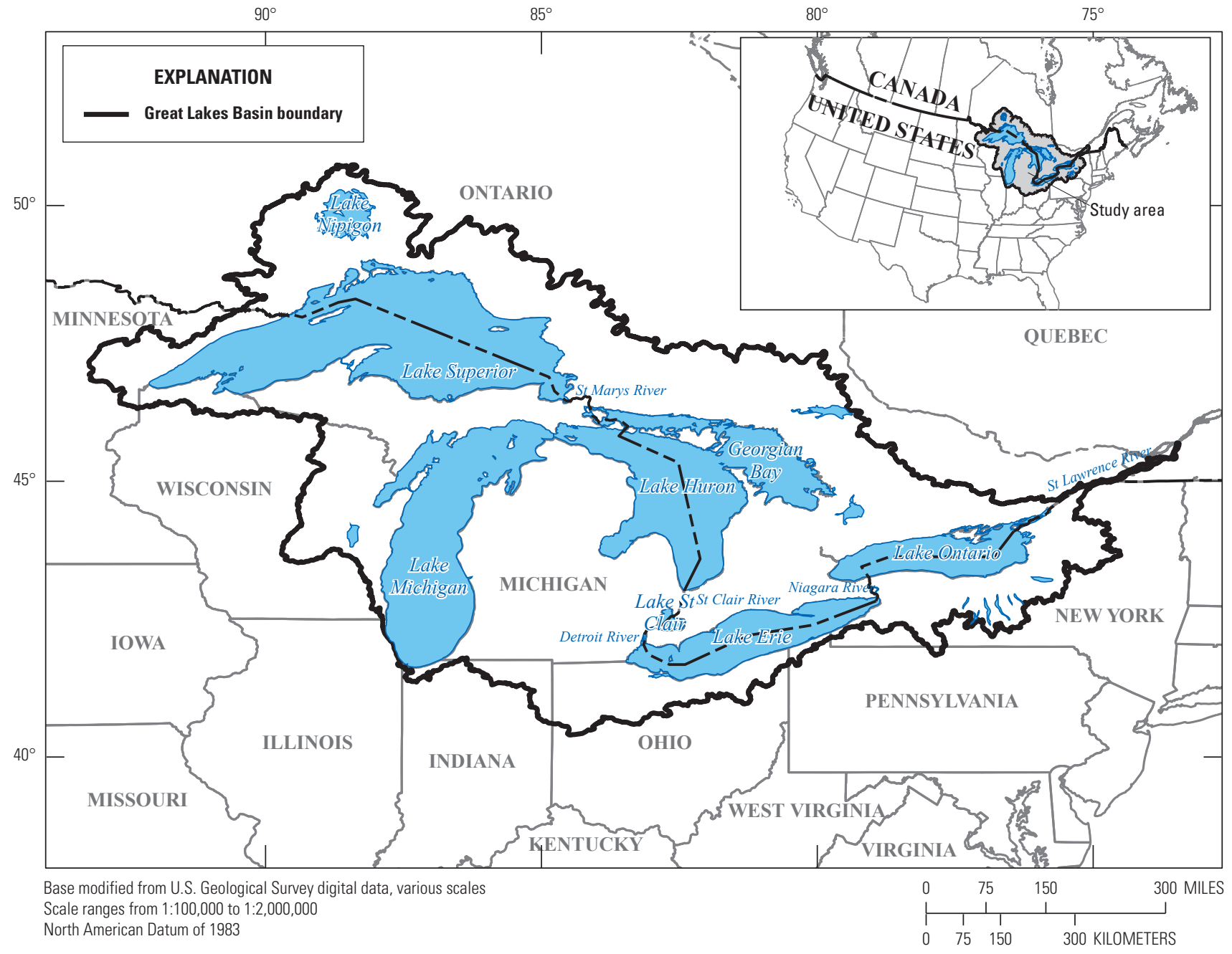

Figure 1. Great Lakes Basin of the United States and Canada. 
Water levels in the Great Lakes fluctuate substantially because of complex interactions among inputs, outputs, and various other factors (Neff and Nicholas, 2005). Precipitation and streamflow are the primary inputs, and evaporation and outflows are the primary outputs (Lenters, 2004; Lenters and others, 2013). Streamflow contributes about 46 percent of inflows to the Great Lakes (Hodgkins and others, 2007). Streamflow in many rivers contributing flow to the Great Lakes has increased since 1960 (Hodgkins and others, 2007; Anderson and Norton, 2013), and precipitation has generally increased in the U.S. Great Lakes Basin over the last century (Hodgkins and others, 2007). Increased streamflow can contribute to increased loading of various constituents such as nutrients, which can contribute to water-quality problems such as harmful algal blooms (U.S. Geological Survey, 2014; Obenour and others, 2016). Increased evaporation resulting from decreased wintertime ice cover (Lenters and others, 2013) is known to offset these increased inputs.

The Great Lakes Restoration Initiative is an interagency collaboration created in 2009 that seeks to address the most significant environmental problems in the Great Lakes ecosystem (https://www.glri.us/). The U.S. Geological Survey (USGS) is involved in the Great Lakes Restoration Initiative to provide scientific support to management decisions and to help measure progress of restoration efforts. As part of the scientific support, a study by the USGS in cooperation with the Great Lakes Restoration Initiative was completed to examine trends in climate, streamflow, lake levels, and major water-budget components within the Great Lakes Basin during water years (WYs) 1960-2015; a WY is the 12-month period from October 1 through September 30 and is designated by the calendar year in which it ends. This study will help to inform future management and restoration activities around the Great Lakes, which may be affected by water-level changes. A study period of WYs 1960-2015 was chosen to be parallel with previous national-level analyses of streamflow trends by Anderson and Norton (2013) and Norton and others (2014). Within this report, all references to years involving water-related data are for WYs, unless specifically noted as calendar years.

\section{Purpose and Scope}

The purpose of this report is to examine trends in climate, streamflow, lake levels, and major water-budget components within the Great Lakes Basin for 1960-2015. Trend analyses were completed for 1960-2015 to build upon the previous national-level analyses of streamflow trends by Anderson and Norton (2013) and Norton and others (2014). Analyses of climate trends were based on monthly air temperature and precipitation data from the Parameterelevation Regressions on Independent Slopes Model (PRISM; Daly and others, 1994, 2002), which are not available for Canada; thus, climate analyses were completed only for areas in the United States.

\section{Previous Studies}

Publications relevant to the topic of climate, streamflow, and lake-level trends in the Great Lakes Basin are too numerous to provide a comprehensive listing in this report, so a selected subset of relevant studies is provided herein. Hodgkins and others (2007) provided a relatively comprehensive list of previous investigations in an analysis of changes in precipitation and streamflow in the Great Lakes Basin for 1915-2004. Neff and Nicholas (2005) provided a thorough description of factors affecting the Great Lakes water balance as part of an analysis of uncertainties in water-balance components. Trends in the Lake Superior water budget were analyzed by Lenters (2004), and focused investigations regarding Great Lakes evaporation were reported by Lenters and others (2013). Smith and others (2016) developed the Great Lakes Dashboard Project (https://www.glerl.noaa. gov/data/dashboard/portal.html) as a graphical interface for examination of a comprehensive database of Great Lakes water-budget components (documented by Hunter and others, 2015) and other relevant datasets.

\section{Methods and Data Sources}

Many of the methods used in this report are like those of Norton and others (2014), who investigated streamflow trends for the Missouri River Basin for 1960-2011. Anderson and Norton (2013) also used similar methods in investigating streamflow trends for the continental United States for 19602012. Resulting trends are applicable only to the 1960-2015 study period and should not be considered indicative of longer-term trends.

The nonparametric Mann-Kendall test (Helsel and Hirsch, 2002; Kendall, 1938) was used in this study to determine statistical significance of time trends for all trend analyses. Trends were considered statistically significant for probability values ( $p$-values) less than or equal to 0.10 for the null hypothesis that Kendall's tau $(\tau)$ equals zero, which is the same significance criterion used by Anderson and Norton (2013) and Norton and others (2014). Kendall's tau measures the degree of correspondence between two variables, with $\tau$ ranging from -1 to 1 . If $\tau=-1$, the data have a perfect negative correlation or downward trend. If $\tau=1$, the data have a perfect positive correlation or upward trend. If $\tau=0$, there is no correlation or trend.

For all trend analyses of this study, the independent $(x)$ variable is time (annual or seasonal), and the dependent ( $y$ ) variable is the applicable climate or hydrologic variable (precipitation, temperature, streamflow, or the like). Values of $p$ and $\tau$ were computed for each trend test. Time series of annual and seasonal (where applicable) climate and hydrologic data were plotted, and a locally weighted regression (LOESS) curve with a span of 0.4 was plotted as an aid in visualizing trends. The LOESS curve is a multivariate smoothing procedure (Cleveland and Devlin, 1988) that can be applied to a time series. Seasons, where applicable, were defined as October-December, January-March, April-June, and July-September. 
An emerging issue has been the potential effect of serial correlation within hydroclimatic datasets on trend analysis (Cohn and Lins, 2005). The existence of serial correlation in time series can cause an inflation of type I errors (that is, declaring a trend as significant when, in fact, no trend exists), but has little effect on trend magnitude (Cohn and Lins, 2005). Much research has been devoted to the development of appropriate approaches for addressing potential effects of serial correlation (Yue and Wang, 2002; Cohn and Lins, 2005; Blain, 2013, 2014); however, approaches are not universally accepted. For example, Dudley and others (2017) and Hodgkins and others (2017) each used three approaches for addressing potential effects of serial correlation.

Initial trend analyses for various time-series datasets were completed without adjusting for serial correlation, as presented in the section "Trends in Climate, Streamflow, and Lake Levels," and statements in this report regarding statistical significance of trends are for unadjusted analyses. Implications regarding adjustments for serial correlation are provided in a subsequent section "Implications Regarding Serial Correlation in Trend Analyses," and effects of serial correlation on the trend analyses for all the time-series datasets considered are addressed within that section.

\section{Climate}

Climate parameters were estimated using output from PRISM (Daly and others, 2002, 2008) for only the U.S. part of the Great Lakes Basin, excluding surfaces of the Great Lakes. Although Daymet climate data (Thornton and others, 2016) are available for Canada, Daymet data did not begin until 1980. In contrast, the PRISM data extend to 1895 (Gibson and others, 2002) and thus cover the study period (1960-2015). A major factor in the selection of this study period is that PRISM data before 1960 generally become progressively less reliable because of the decreasing density of source data from climate stations. PRISM interpolates monthly total precipitation, monthly means of daily minimum air temperature $\left(T_{\min }\right)$, and monthly means of daily maximum air temperature $\left(T_{\max }\right)$ from weather stations to a 2.5 -arc-minute grid for the conterminous United States.

Monthly PRISM data of total precipitation, $T_{\min }$, and $T_{\max }$ were aggregated to obtain datasets of annual total precipitation and annual means of $T_{\min }$ and $T_{\max }$ for the U.S. land part of the Great Lakes Basin and for the contributing drainage area for each of the five individual Great Lakes. Trend tests for the three climate parameters were completed for all individual 2.5-arc-minute grid cells for the U.S. land part of the Great Lakes Basin and a surrounding buffer. Trend tests for the gridded data for total precipitation, $T_{\min }$, and $T_{\max }$ were completed for the annual and seasonal time series. These gridded data were used to show the spatial distribution of trends in the climatic data relative to trends in streamflow data. Figures showing the spatial distribution of climatic trends include only the 2.5 -arc-minute grid cells having statistically significant trends, as opposed to streamflow trends, for which significant and nonsignificant trends are shown coincident with climate trends. Within the remainder of this report, all references to spatial trends in gridded PRISM data refer specifically to statistically significant trends, whereas significant and nonsignificant trends are considered for other variables. For example, trends in aggregated PRISM data are tested for statistical significance, similar to analyses for various other nonclimatic data that are considered.

\section{Streamflow}

Streamgages for analyses of annual and seasonal streamflow trends in the Great Lakes Basin were selected based on having continuous records of monthly and annual streamflow for 1960-2015. A total of 103 USGS streamgages in the United States and 35 Environment and Climate Change Canada (ECCC) streamgages in Canada met this criterion (fig. 2; table 1.1 in the appendix). ECCC streamgages meeting this criterion are notably sparse, with all qualifying streamgages east of Lake Huron. No criterion was established for the culling of multiple streamgages within any individual drainage basin, which consequently maximized streamgage density when comparing streamflow trends to the spatial distribution of trends in climate data.

Monthly and annual streamflow data for the 103 USGS streamgages were retrieved from the USGS National Water Information System, available at https://doi.org/10.5066/ F7P55KJN (U.S. Geological Survey, 2016). Monthly and annual streamflow data for the 35 ECCC streamgages were retrieved from the ECCC hydrological database, HYDAT, available at https://www.ec.gc.ca/rhc-wsc/default. asp?lang=En\&n=9018B5EC-1 (Environment and Climate Change Canada, 2016). Time series of annual and seasonal streamflow data were plotted along with results of timetrend testing. Spatial distributions of annual and seasonal streamflow trends were shown relative to spatial distributions of climatic trends.

\section{Lake Levels}

Monthly and annual lake-level records for each of the Great Lakes were analyzed for trends for 1960-2015. Historical monthly lake-level records were obtained from the U.S. Army Corps of Engineers (2017). Analyses of trends also were included for major water-budget components for the Great Lakes, including lake outflow, overlake precipitation, overlake evaporation, and runoff. Analyses of waterbudget components used data products obtained from the Great Lakes Environmental Research Laboratory monthly hydrometeorological database (Hunter and others, 2015) and the Great Lakes Dashboard Project (Smith and others, 2016). 


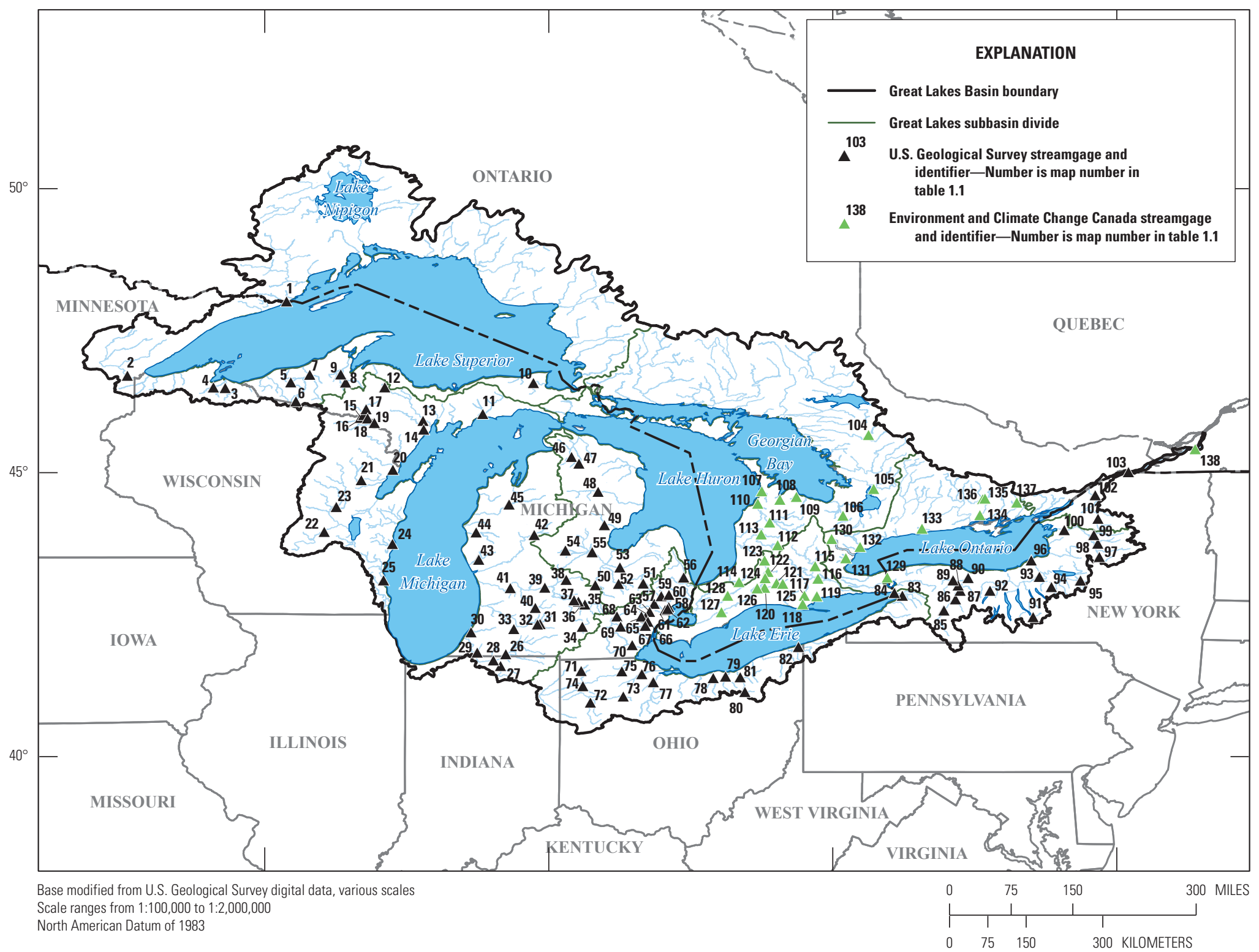

Figure 2. Streamgages in the Great Lakes Basin in the United States and Canada used for streamflow trend analyses, water years $1960-2015$. 


\section{Trends in Climate, Streamflow, and Lake Levels}

Climate, streamflow, and lake-level data for the Great Lakes Basin were analyzed for trends for 1960-2015. Trends in water-budget components for each of the Great Lakes also were analyzed to examine driving factors for lakelevel trends. Resulting trends are applicable only to the 19602015 study period and should not be considered indicative of longer-term trends.

\section{Climate Trends}

Trends in annual climate data (total precipitation, $T_{\min }$, and $T_{\max }$ from aggregated PRISM data) for 1960-2015 for the U.S. part of the Great Lakes Basin (excluding surfaces of the Great Lakes) are shown in figure 3, and climate trends for the contributing drainage areas for each of the five individual lakes are shown in figures 4-8. For the U.S. part of the Great Lakes Basin, a statistically significant upward trend in total precipitation ( $p$-value $=0.0066, \tau=0.2494$ ) is indicated (fig. $3 A$ ). This trend is driven by substantial increases in precipitation during the 1960s through the early 1970s and during years since about 2000. Except for the contributing drainage area for Lake Superior, the individual lake subbasins have similar upward trends driven by substantial increases in precipitation during the same general periods (graph $A$ in figs. 4-8). No significant trend in precipitation is indicated for the Lake Superior subbasin (fig. 4A).

The trends in annual precipitation for the Great Lakes Basin are consistent with those reported by Hodgkins and others (2007), who reported predominantly upward trends in precipitation for three periods (calendar years 1915-2004, 1935-2004, and 1955-2004). Data presented by Hodgkins and others (2007) indicated substantial drought conditions during calendar years 1960-1965, which is consistent with figure $3 \mathrm{~A}$. Below-mean precipitation was observed for 7 of the first 8 years considered and above-mean precipitation was observed for 9 of the last 10 years considered (fig. $3 \mathrm{~A}$ ); thus, it must be recognized that the trends in annual precipitation are driven by both tails of the study period that was selected. As such, the resulting precipitation trends are applicable only to the study period of WYs 1960-2015 and should not be considered indicative of longer-term trends. The associated effects on streamflow and lake levels for the Great Lakes Basin must also be recognized; however, results of Hodgkins and others (2007) indicate that the WYs 1960-2015 precipitation trends for the study described in this report fall within the general context of the calendar years 1915-2004 precipitation trends.

Annual trends in $T_{\min }$ and $T_{\max }$ are shown in graphs $B$ and $C$, respectively, of figures $3-8$. For the U.S. land part of the Great Lakes Basin (fig. 3B), a statistically significant upward trend in $T_{\min }$ is indicated ( $p$-value $=0.0328, \tau=0.1961$ ); however, the trend for $T_{\max }$ is not significant and in effect is neutral (fig. $3 C, p$-value $=0.9212, \tau=-0.0091$ ). Annual trends in $T_{\min }$ and $T_{\max }$ for the individual lake subbasins are generally similar to those for the Great Lakes Basin. An upward trend in $T_{\min }$ is indicated for the Lake Superior subbasin (fig. 4B), but the $p$-value of 0.1134 is slightly greater than the significance criterion of 0.10 . Upward trends in $T_{\min }$ are statistically significant for the other four individual lake subbasins (graph $B$ in figs. 5-8). Trends in $T_{\max }$ are nonsignificant for all five of the individual lake subbasins (graph $C$ in figs. 4-8).

\section{Streamflow Trends}

Trends in annual and seasonal streamflow for 1960-2015 were analyzed for 103 USGS streamgages and 35 ECCC streamgages within the Great Lakes Basin (fig. 2), with results provided in table 1.2 in the appendix. Of the 103 USGS streamgages considered, 71 had significant trends in annual streamflow (54 upward and 17 downward). Of these 71 streamgages, all but 1 had at least one season with a significant trend that matched the annual trend direction (table 1.2, streamgage 04151500, map number 53). Of the 32 USGS streamgages without significant annual trends, 17 had at least one season with a significant trend, including 14 streamgages with at least one upward trend and 3 streamgages with at least one downward trend. Considering all 103 USGS streamgages, significant upward seasonal trends were most common for October-December and July-September, with 45 and 51 significant trends, respectively. Considering all 103 USGS streamgages, significant downward seasonal trends were most common for April-June and July-September, with 17 and 18 significant trends, respectively.

Of the 35 ECCC streamgages considered in the analysis, 22 had significant upward trends in annual streamflow. None of the ECCC streamgages had significant downward annual trends. All but 1 of the 22 ECCC streamgages with significant annual trends had at least one season with a significant upward trend (table 1.2, streamgage 02GG002, map number 128). Of the 13 ECCC streamgages without significant annual trends, only 3 did not have a significant seasonal trend. Only 1 downward seasonal trend was significant among all 35 ECCC streamgages (table 1.2, streamgage 02HL004, map number 136). Considering all 35 ECCC streamgages, significant upward seasonal trends were most common for October-December, with 27 significant trends, followed by January-March and July-September, with 18 and 17 significant trends, respectively. April-June had only two significant upward seasonal trends, and the only significant downward seasonal trend. 
A. Annual mean of total precipitation [probability value $(p$-value $)=0.0066$, Kendall's tau $(\tau)=0.2494$ ]

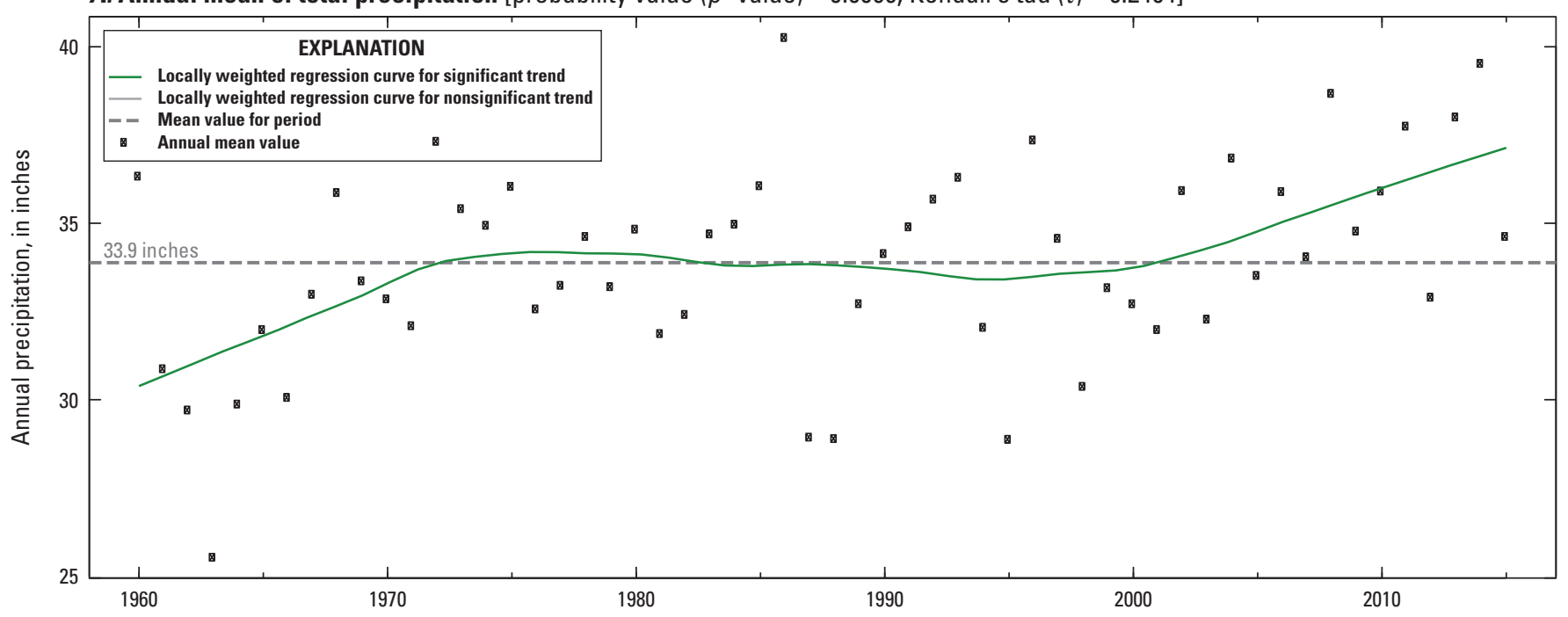

B. Annual mean of monthly mean daily minimum air temperature [probability value $(p$-value $)=0.0328$, Kendall's tau $(\tau)=0.1961$ ]

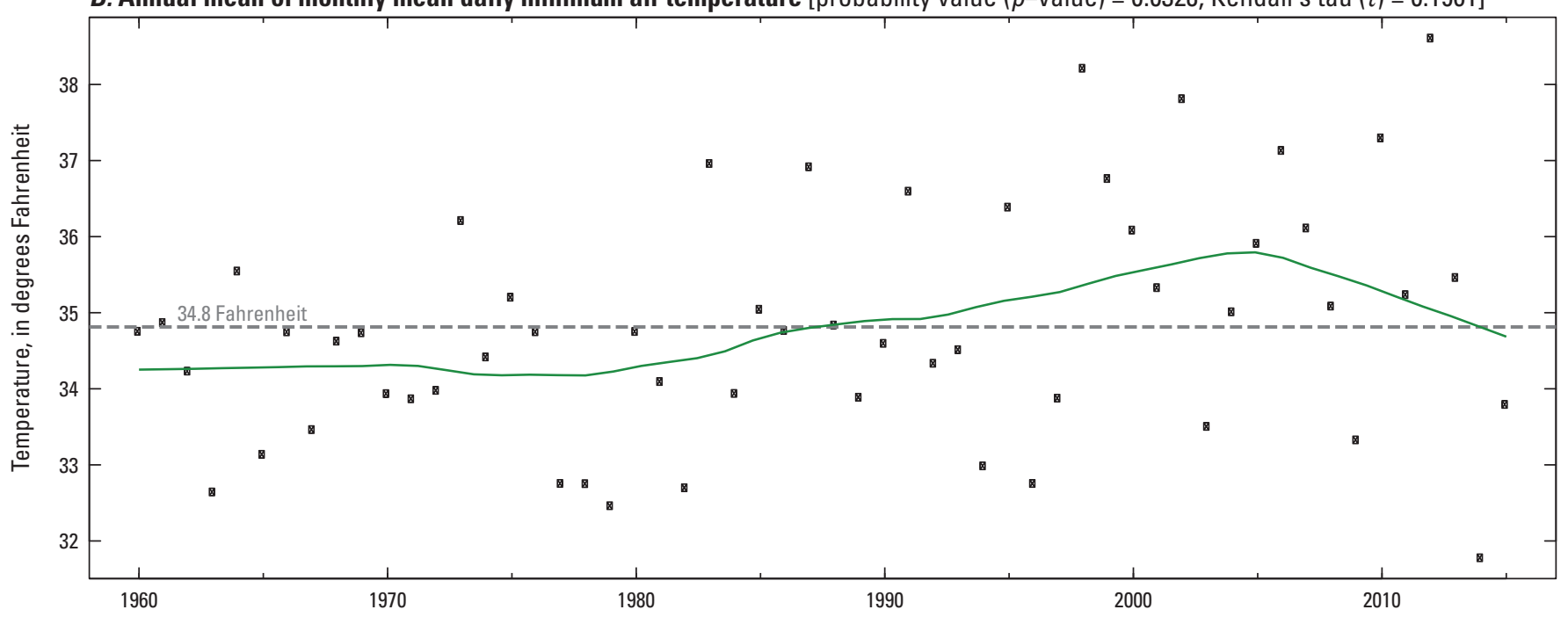

C. Annual mean of monthly mean daily maximum air temperature [probability value $(p$-value $)=0.9212$, Kendall's tau $(\tau)=-0.0091$ ]

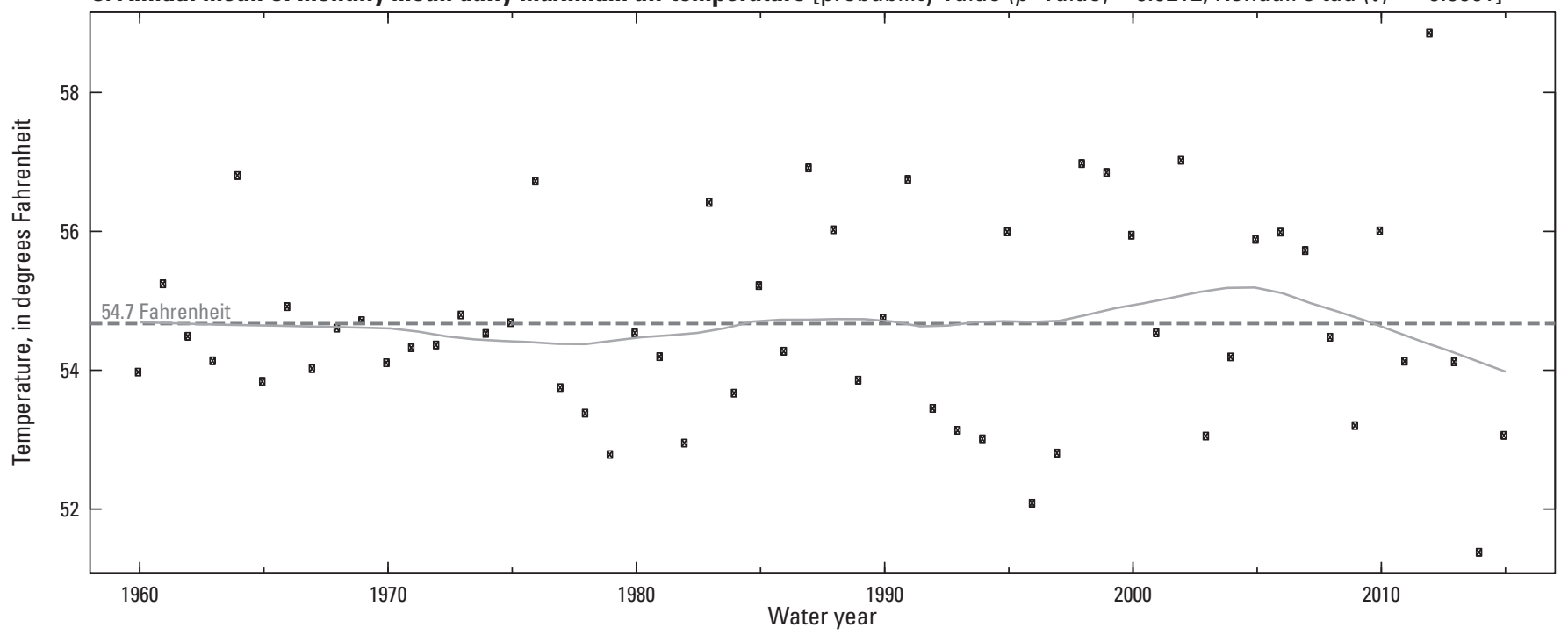

Figure 3. Trends in climate data for the land part of the Great Lakes Basin in the United States, water years 1960-2015. A, annual mean of total precipitation; $B$, annual mean of monthly mean daily minimum air temperature; and $C$, annual mean of monthly mean daily maximum air temperature. 


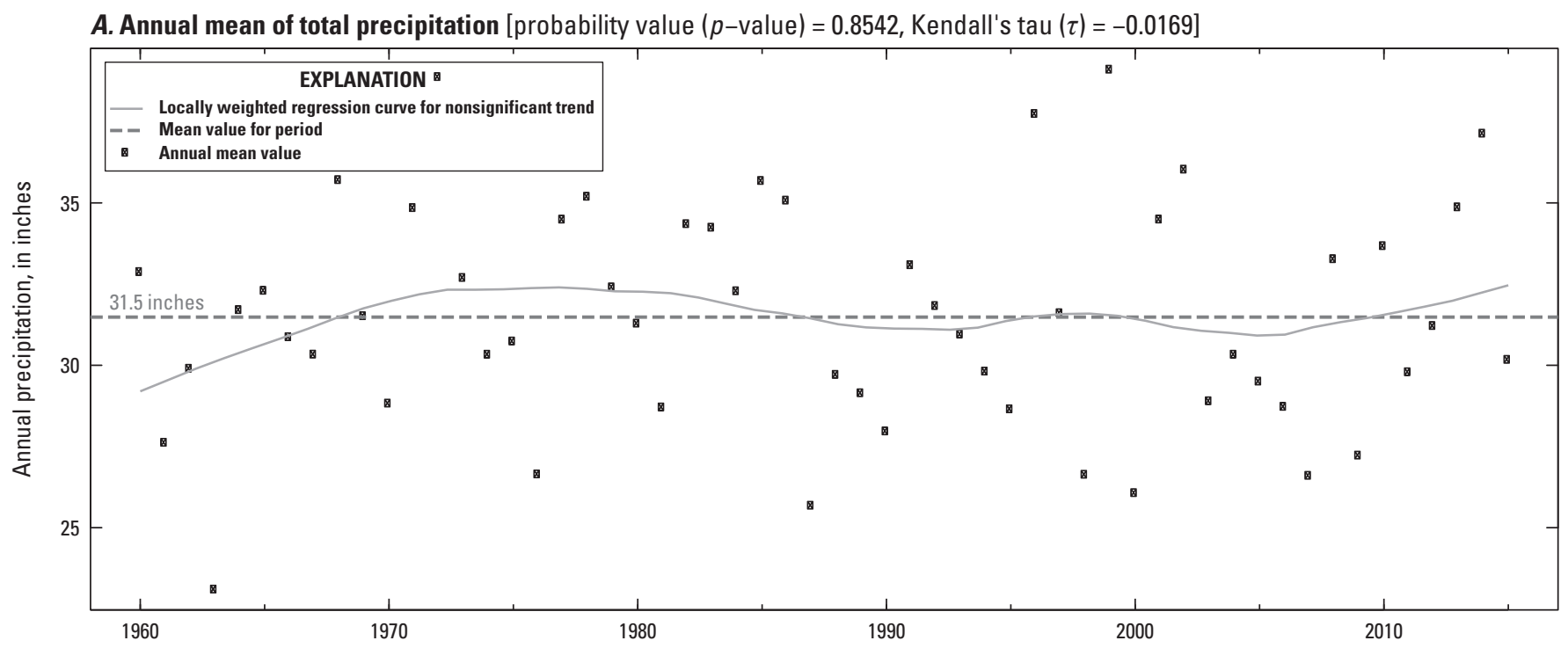

B. Annual mean of monthly mean daily minimum air temperature [probability value $(p$-value $)=0.1134$, Kendall's tau $(\tau)=0.1455$ ]

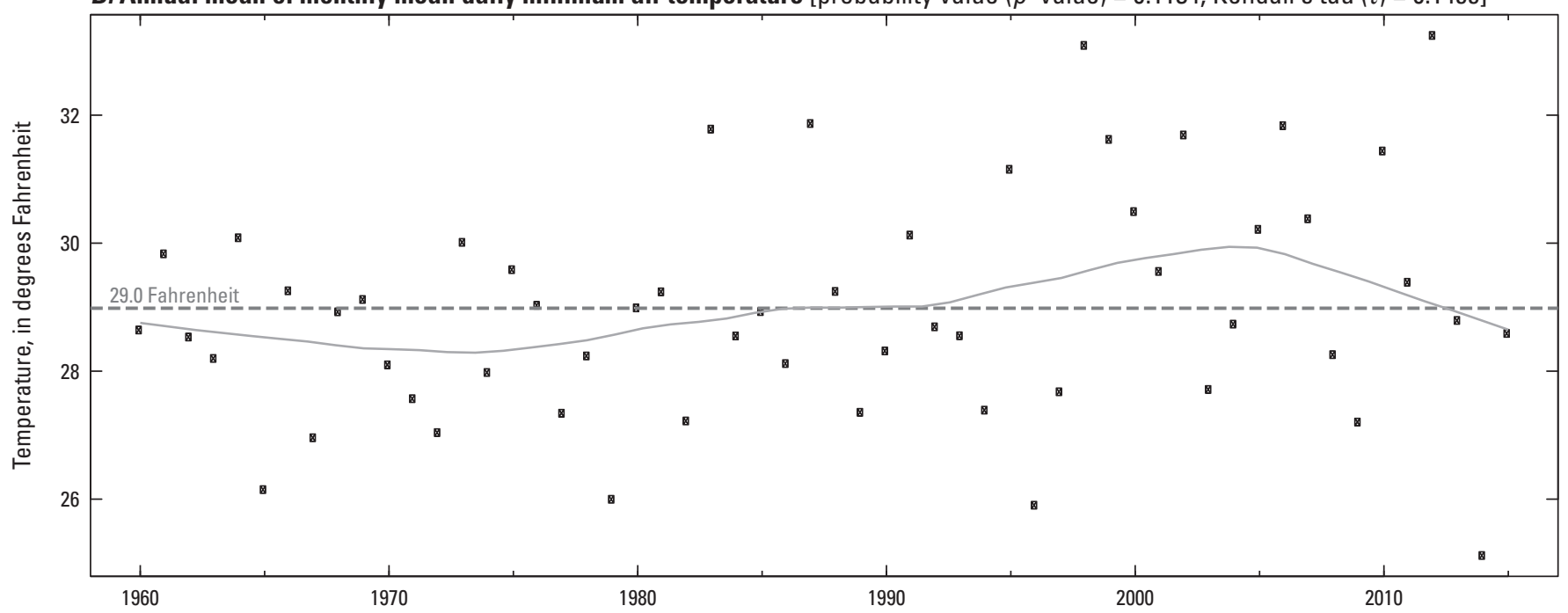

C. Annual mean of monthly mean daily maximum air temperature [probability value $(p$-value $)=0.8101$, Kendall's tau $(\tau)=-0.0221$ ]

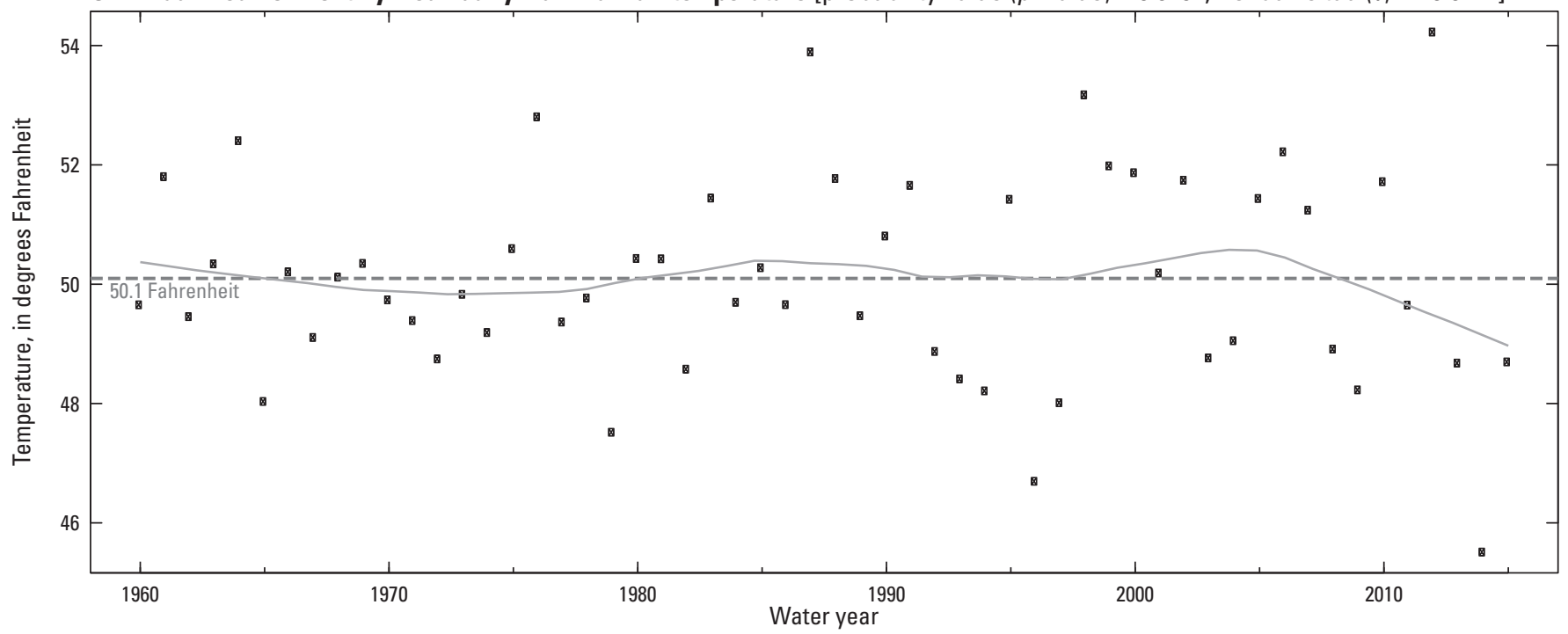

Figure 4. Trends in climate data for the land part of the Lake Superior subbasin in the United States, water years 1960-2015. $A$, annual mean of total precipitation; $B$, annual mean of monthly mean daily minimum air temperature; and $C$, annual mean of monthly mean daily maximum air temperature. 
A. Annual mean of total precipitation [probability value $(p$-value $)=0.0726$, Kendall's tau $(\tau)=0.1649$ ]

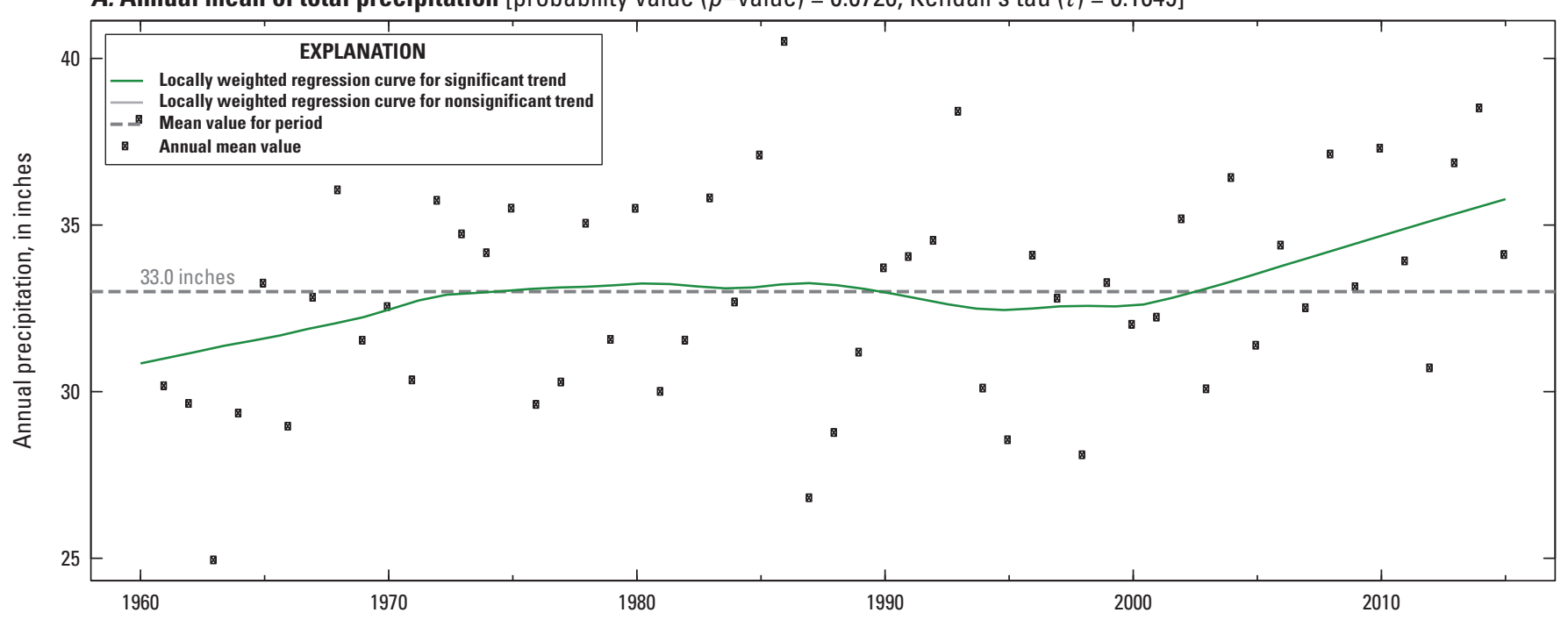

B. Annual mean of monthly mean daily minimum air temperature [probability value $(p$-value $)=0.0704$, Kendall's tau $(\tau)=0.1662$ ]

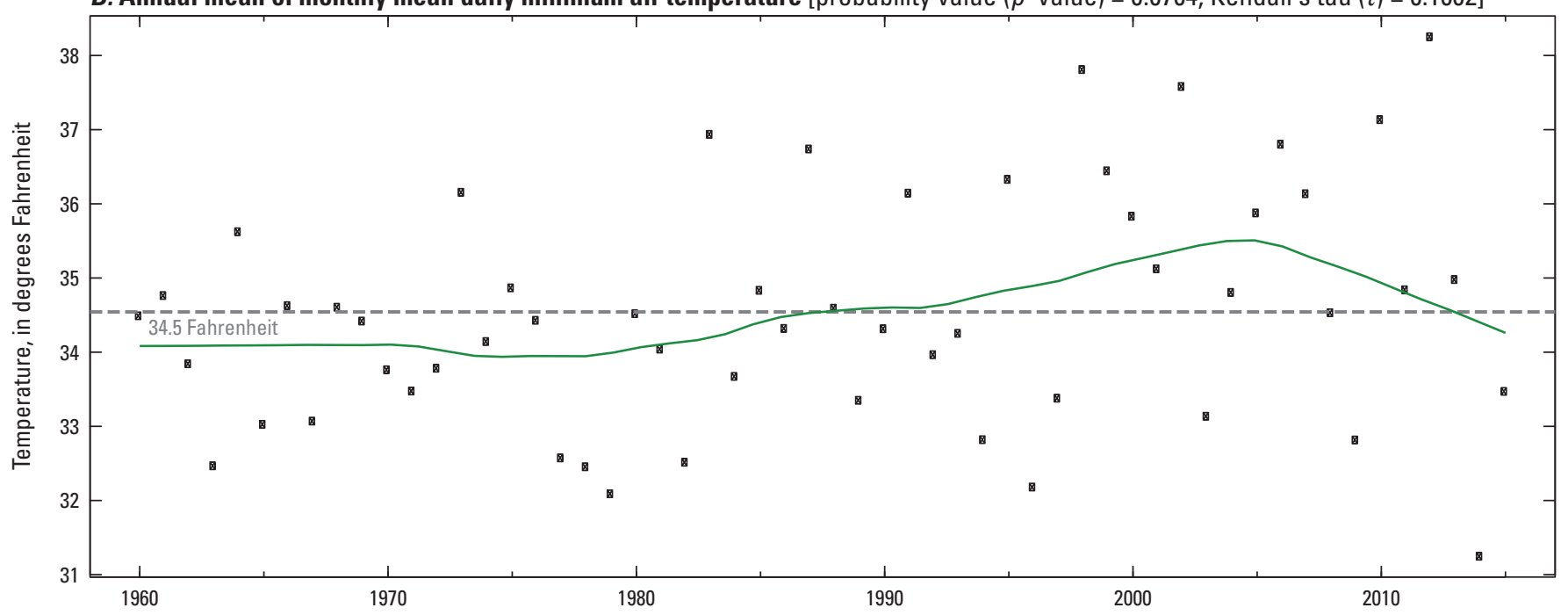

C. Annual mean of monthly mean daily maximum air temperature [probability value $(p$-value $)=0.6208$, Kendall's tau $(\tau)=-0.0455$ ]

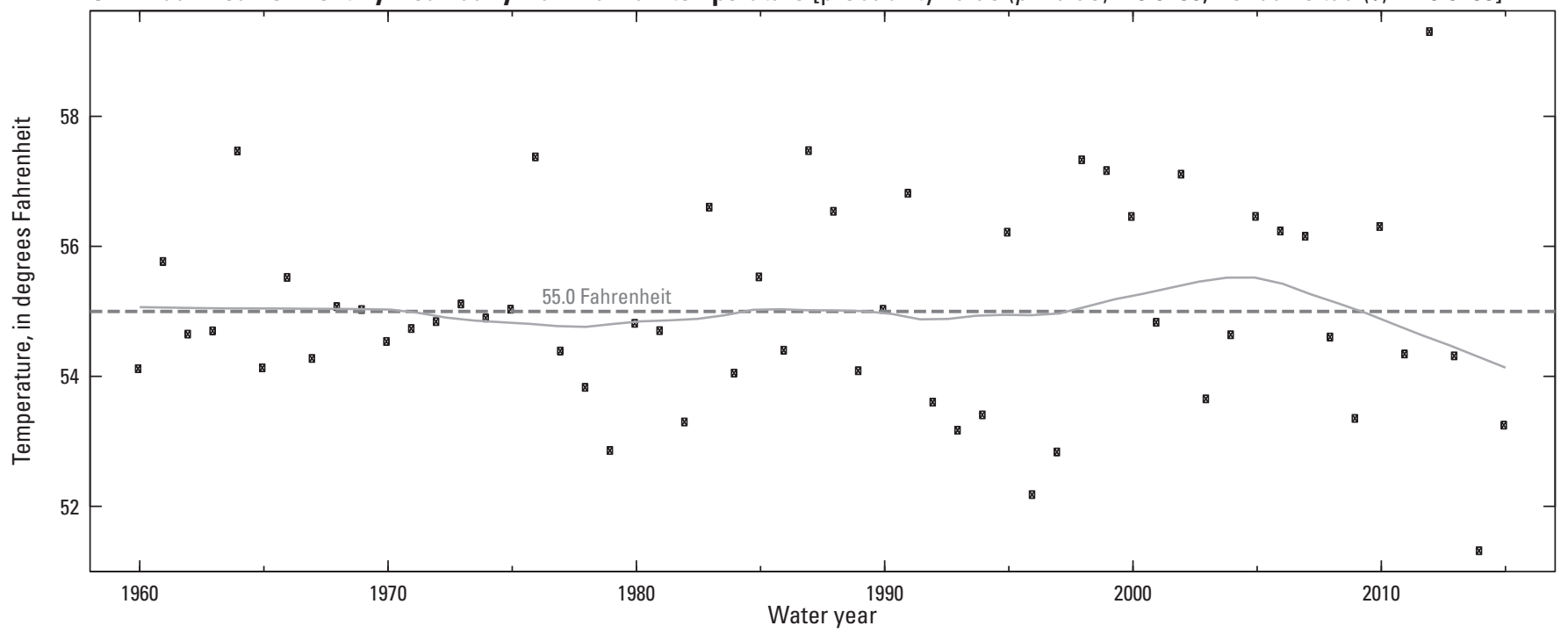

Figure 5. Trends in climate data for the land part of the Lake Michigan subbasin in the United States, water years 1960-2015. $A$, annual mean of total precipitation; $B$, annual mean of monthly mean daily minimum air temperature; and $C$, annual mean of monthly mean daily maximum air temperature. 


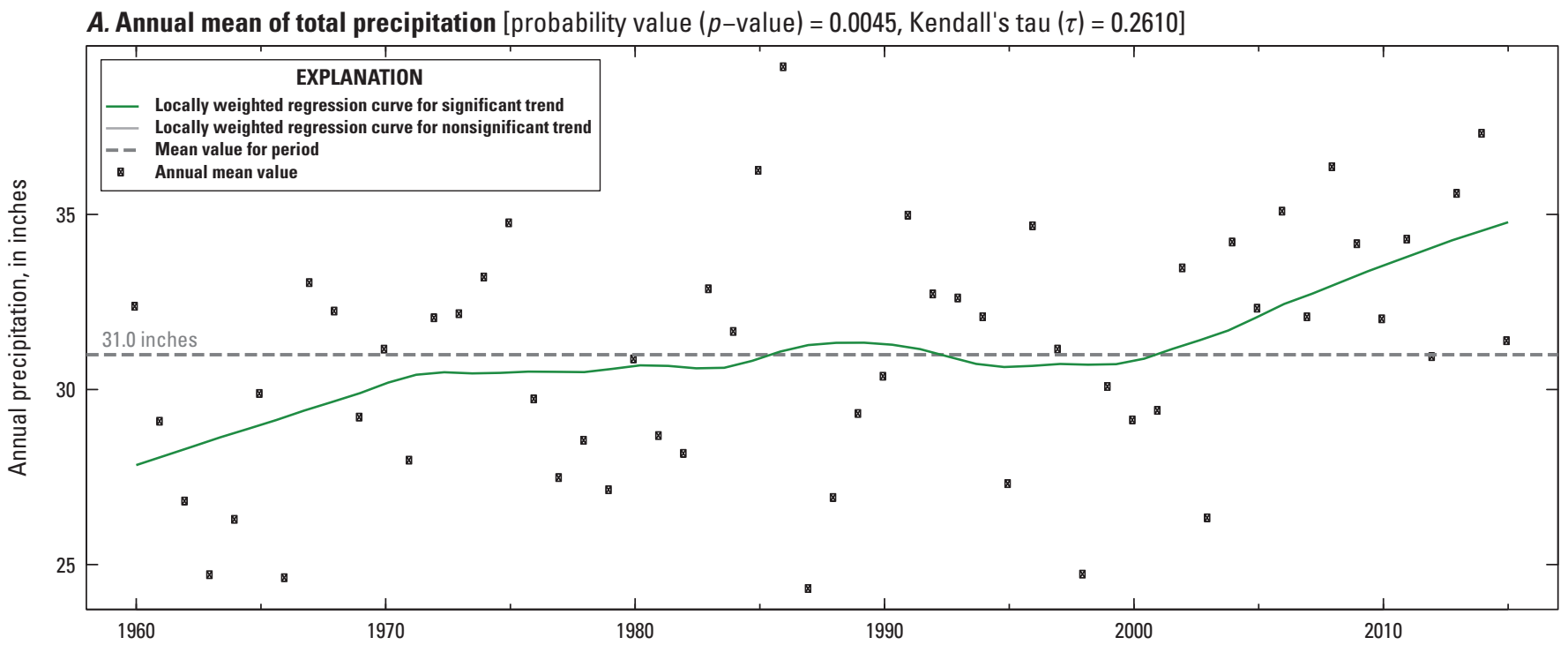

B. Annual mean of monthly mean daily minimum air temperature [probability value $(p$-value $)=0.0796$, Kendall's tau $(\tau)=0.1610$ ]

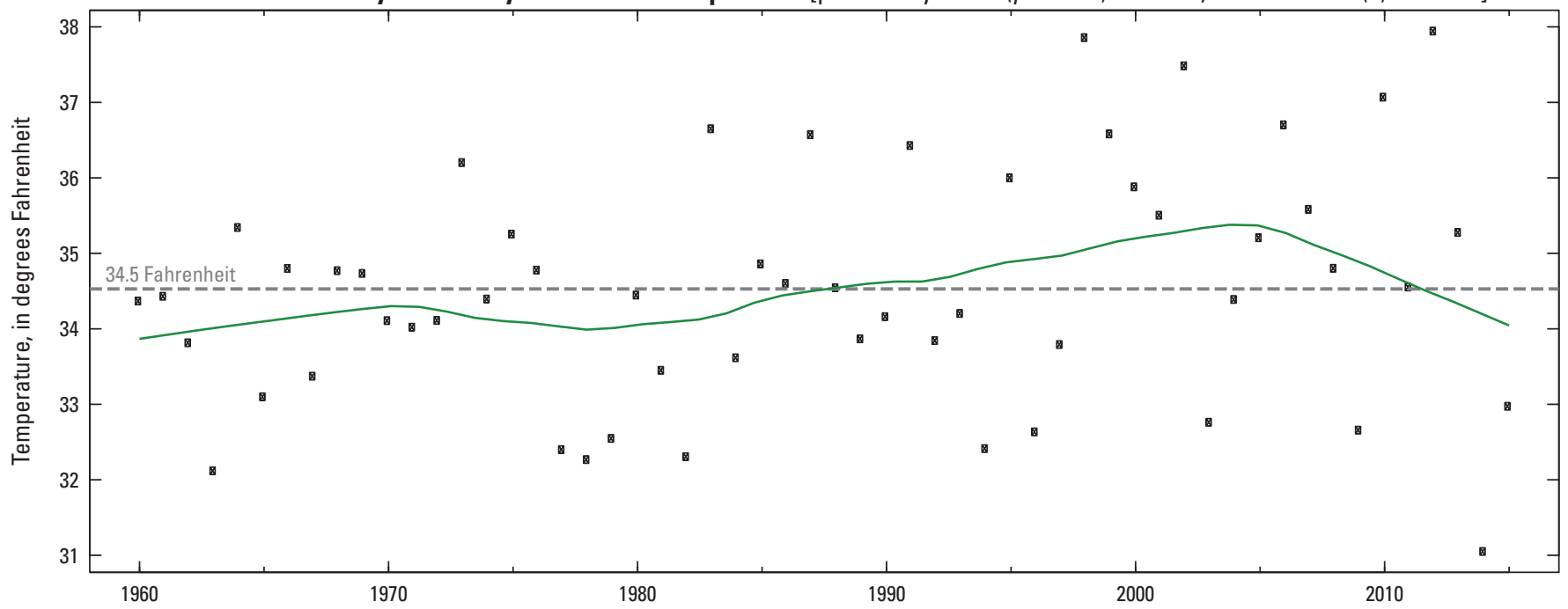

C. Annual mean of monthly mean daily maximum air temperature [probability value $(p$-value $)=0.9887$, Kendall's tau $(\tau)=0.0013$ ]

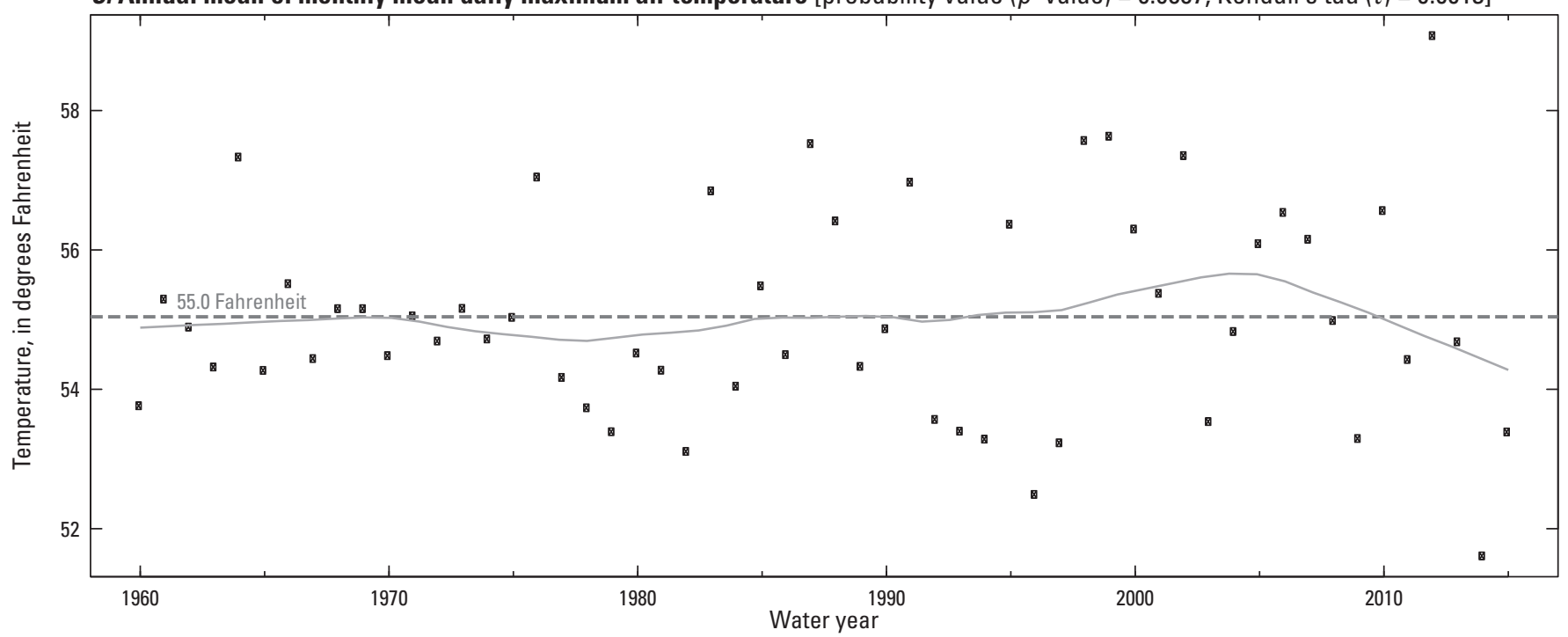

Figure 6. Trends in climate data for the land part of the Lake Huron subbasin in the United States, water years 1960-2015. $A$, annual mean of total precipitation; $B$, annual mean of monthly mean daily minimum air temperature; and $C$, annual mean of monthly mean daily maximum air temperature. 
A. Annual mean of total precipitation [probability value ( $p$-value) less than 0.0001 , Kendall's tau $(\tau)=0.3948$ ]

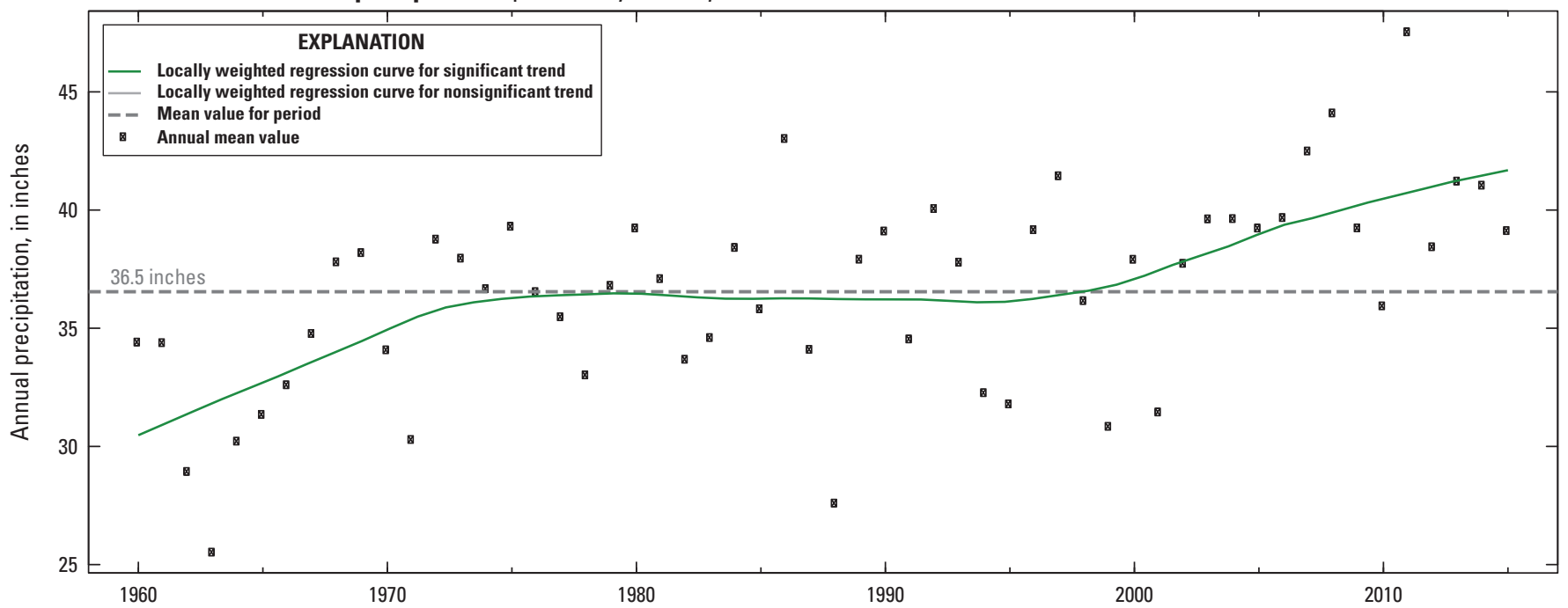

B. Annual mean of monthly mean daily minimum air temperature [probability value $(p-$ value $)=0.0041$, Kendall's tau $(\tau)=0.2636$ ]

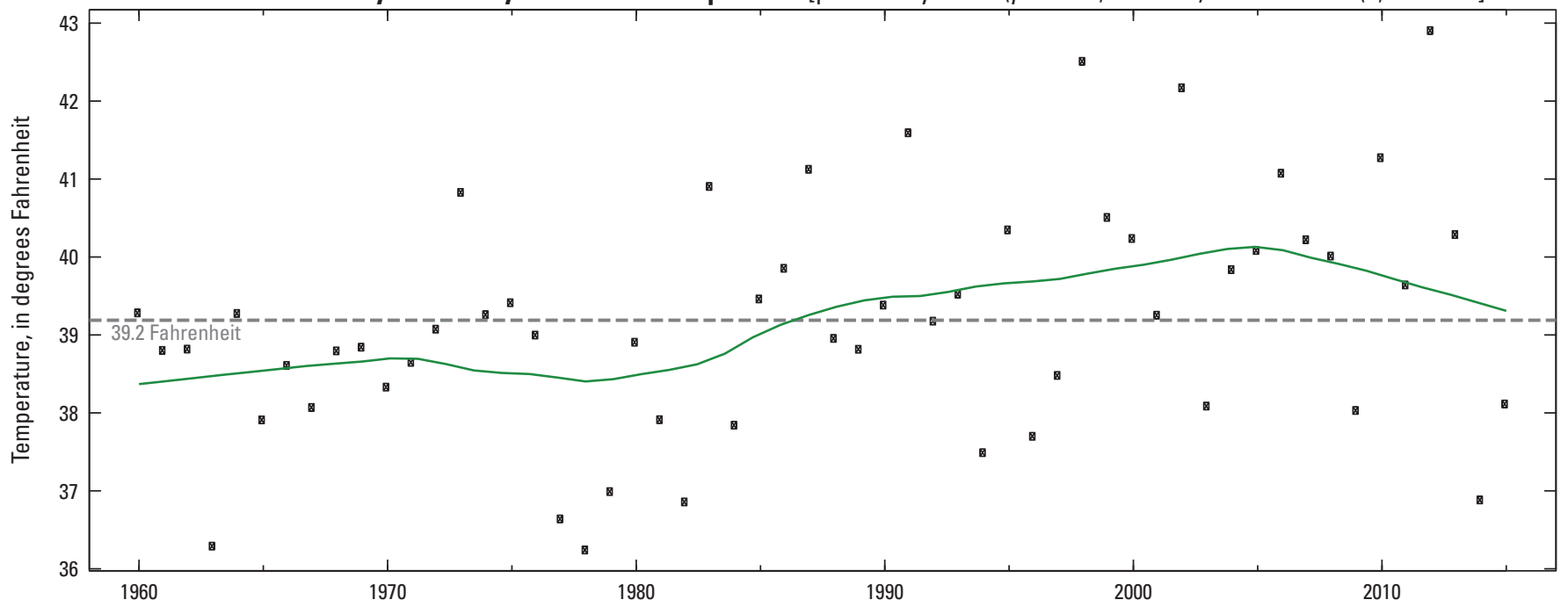

C. Annual mean of monthly mean daily maximum air temperature [probability value $(p-$ value $)=0.9100$, Kendall's tau $(\tau)=-0.0104$ ]

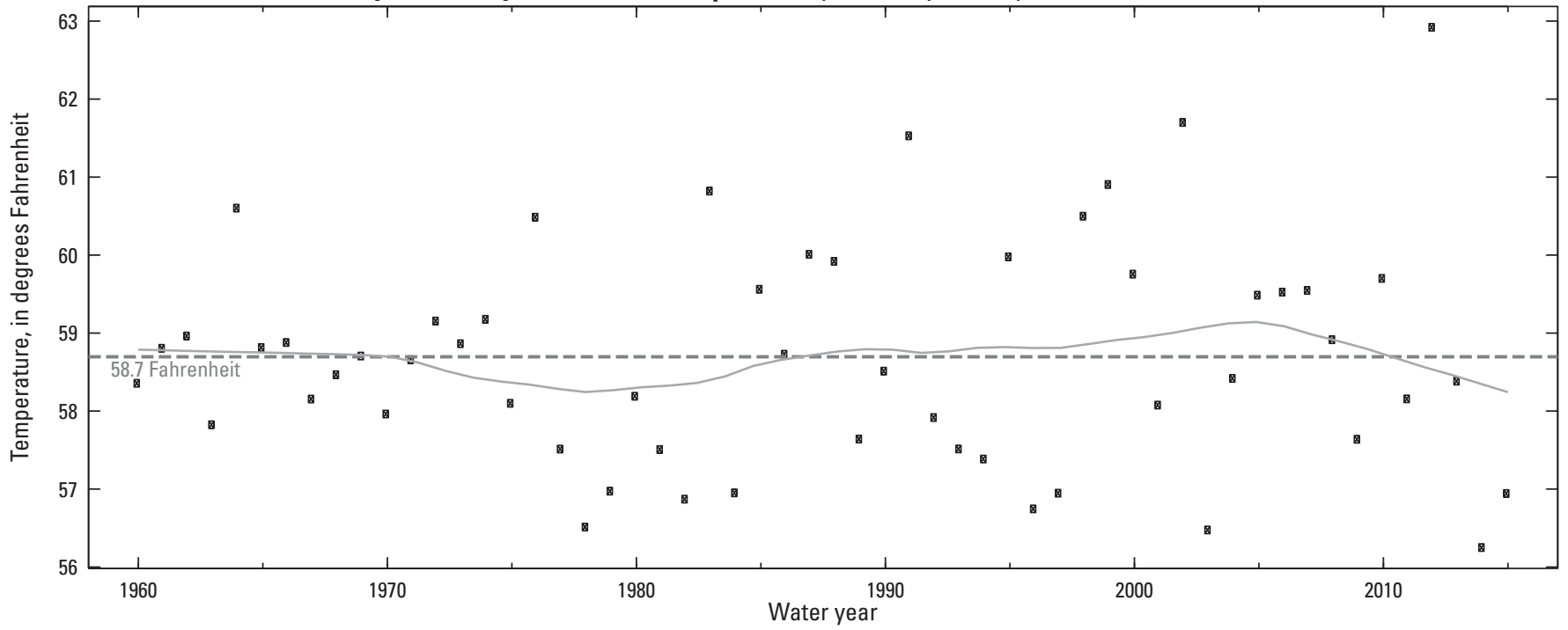

Figure 7. Trends in climate data for the land part of the Lake Erie subbasin in the United States, water years 1960-2015. $A$, annual mean of total precipitation; $B$, annual mean of monthly mean daily minimum air temperature; and $C$, annual mean of monthly mean daily maximum air temperature. 
A. Annual mean of total precipitation [probability value $(p$-value $)=0.0026$, Kendall's tau $(\tau)=0.2766$ ]

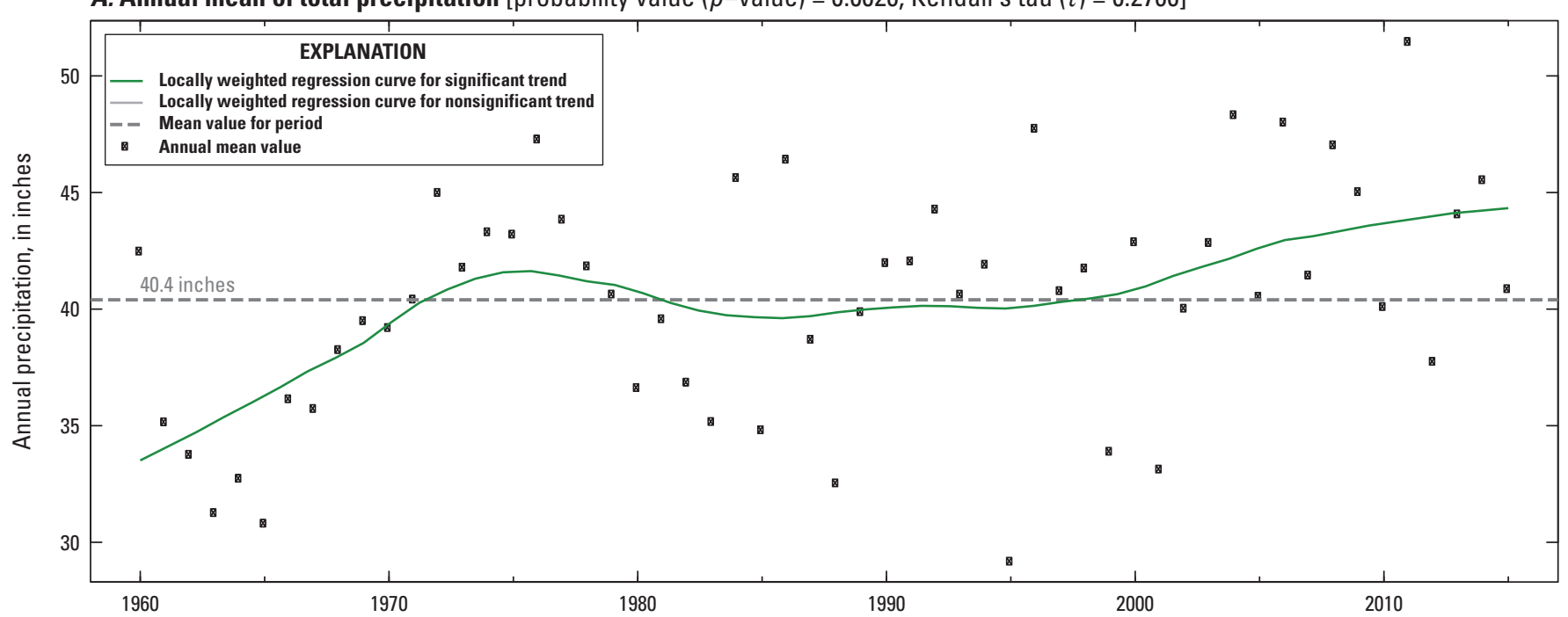

B. Annual mean of monthly mean daily minimum air temperature [probability value $(p$-value $)=0.0011$, Kendall's tau $(\tau)=0.2987$ ]

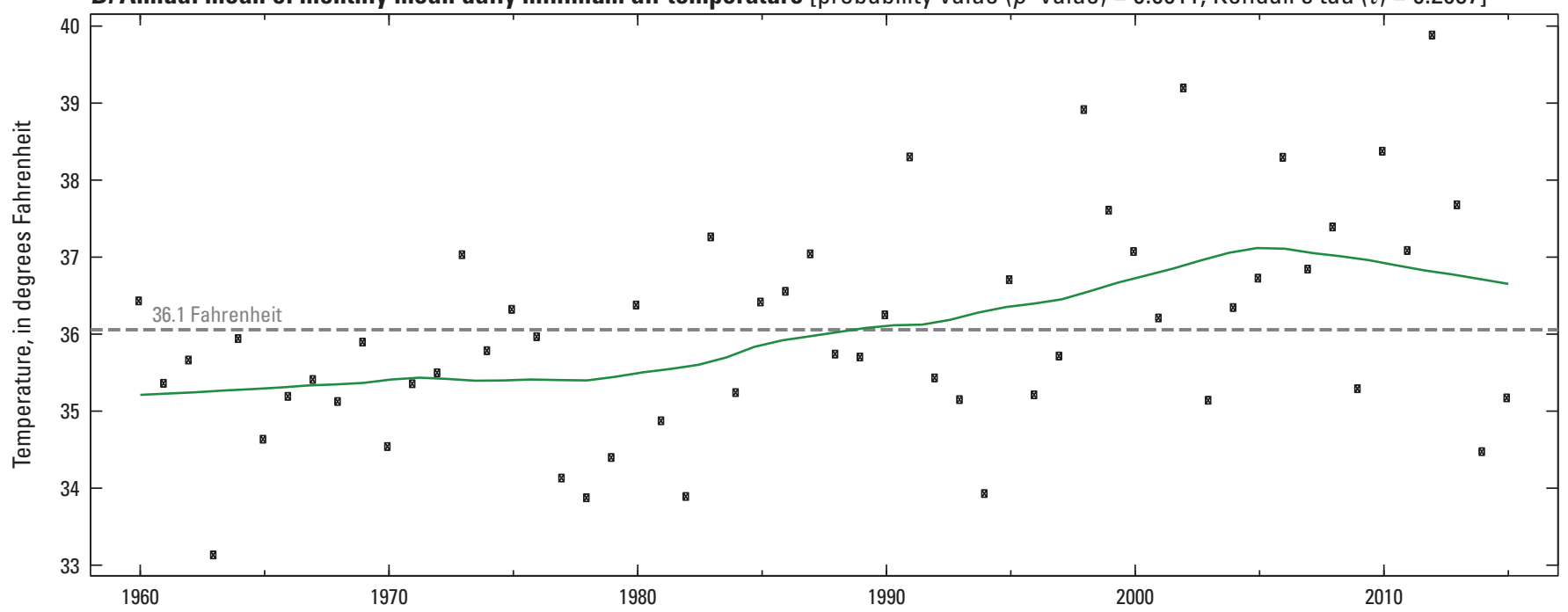

C. Annual mean of monthly mean daily maximum air temperature [probability value $(p$-value $)=0.3294$, $\operatorname{Kendall's~tau~}(\tau)=0.0896$ ]

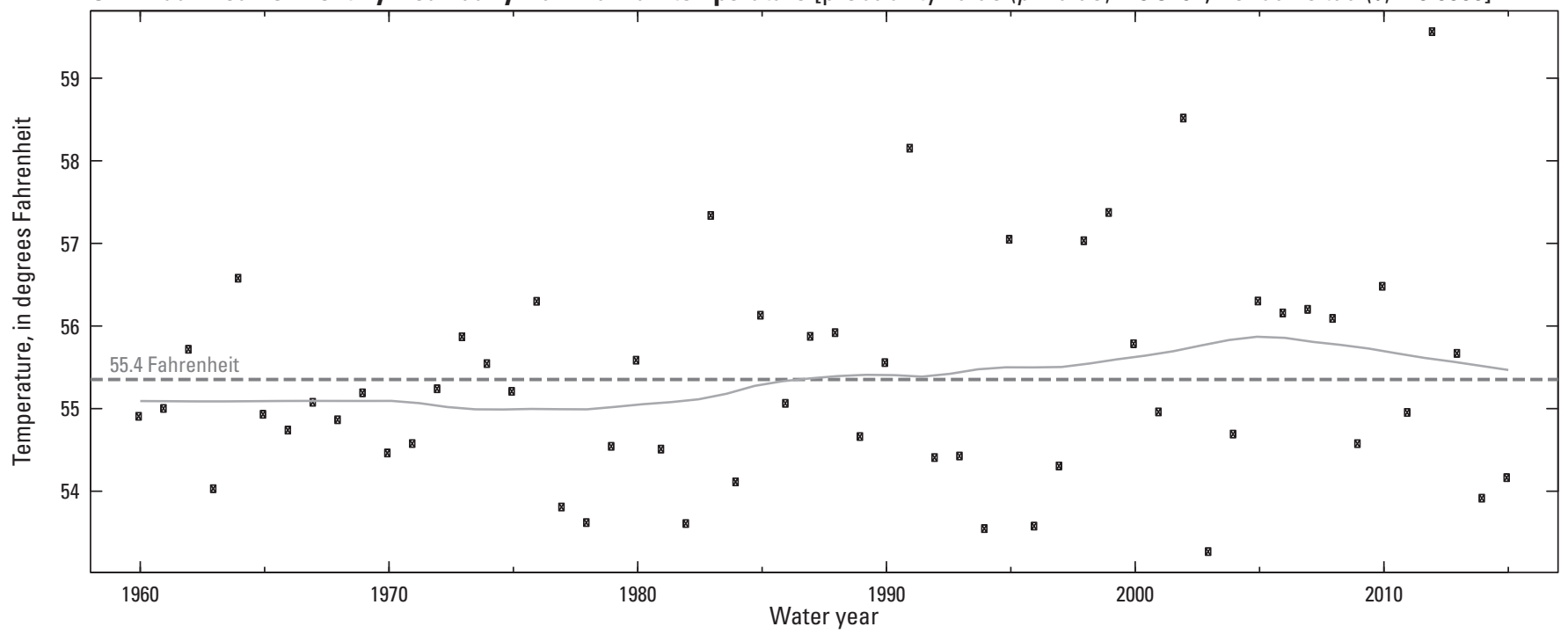

Figure 8. Trends in climate data for the land part of the Lake Ontario subbasin in the United States, water years 1960-2015. $A$, annual mean of total precipitation; $B$, annual mean of monthly mean daily minimum air temperature; and $C$, annual mean of monthly mean daily maximum air temperature. 
Mean streamflow data (annual, seasonal, and monthly) for all 138 USGS and ECCC streamgages are provided in table 1.1, with minimum and maximum seasonal values for each streamgage indicated by different fonts. July-September was the predominant season for minimum streamflow ( 93 of 103 USGS streamgages and 33 of 35 ECCC streamgages). Of the two ECCC streamgages that are exceptions, one is immediately downstream from Lake Erie (streamgage 02HA003, map number 129, fig. 2) and one is immediately downstream from Lake Ontario (streamgage 02OA016, map number 138), so minimum streamflow for both is driven by outflow from most or all of the Great Lakes, rather than runoff from much smaller drainage basins. Similarly, of the 10 USGS streamgages that are exceptions, 1 is downstream from Lake Erie (streamgage 04216000, map number 84) and 1 is downstream from Lake Ontario (streamgage 04264331, map number 103).

The predominant seasons for maximum streamflow (table 1.1) were January-March (52 of 103 USGS streamgages and 23 of 35 ECCC streamgages) and April-June (49 USGS streamgages and 12 ECCC streamgages). Of all 138 streamgages, only 2 had maxima for other seasons, and 1 of these 2 is downstream from Lake Ontario (streamgage 04264331, map number 103). Of the 75 streamgages for which January-March was the predominant season for maximum streamflow, only 19 had significant upward January-March trends and annual trends (10 USGS and 9 ECCC) (table 1.4). Of the 61 streamgages for which April-June was the predominant season for maximum streamflow, only 8 (all USGS), had significant upward April-June trends and annual trends (table 1.4); thus, significant upward seasonal trends in seasons with maximum streamflow were not necessarily strong drivers of annual trends.

Graphs of annual and seasonal streamflow trends are provided in the appendix for all USGS streamgages (figs. 1.1 through 1.103) and ECCC streamgages (figs. 1.104 through 1.138). Each figure includes one graph showing annual data and four graphs showing seasonal data. LOESS curves are provided to assist in visualizing trends, and the LOESS curves are coded with colors and line types to distinguish between significant and nonsignificant trends.

Trends in annual streamflow, relative to the spatial distribution of trends in climate (total precipitation, $T_{\min }$, and $T_{\max }$ ) for 2.5-arc-minute PRISM grid cells, are shown in figure 9. The 71 USGS and 22 ECCC streamgages with statistically significant trends are distinguished from those with nonsignificant trends; however, only statistically significant trends in climate data are shown for 2.5-arc-minute PRISM grid cells, as described previously in the section "Methods and Data Sources." The PRISM data within the U.S. land part of the Great Lakes Basin and a surrounding buffer indicate that the climate trends are generally consistent with broader national-scale trends. Annual streamflow trends, relative to trends in annual total precipitation, are shown in figure $9 \mathrm{~A}$, which clearly indicates a strong spatial correlation between the upward trends in streamflow and precipitation in the area east of Lake Michigan. Trends in $T_{\min }$ are upward throughout most of the area east of Lake Michigan (fig. 9B), but trends in $T_{\max }$ are generally neutral throughout the U.S. side of the Great Lakes Basin (fig. 9C). Upward trends in annual $T_{\min }$ (and the presumed associated upward trends in evapotranspiration) apparently are insufficient to offset the upward trends in annual total precipitation, relative to effects on annual streamflow. Trends in annual streamflow and annual total precipitation generally are similar to those reported for somewhat different timeframes by Hodgkins and others (2007).

Except for a single streamgage, the statistically significant downward trends in annual streamflow are concentrated northwest of Lake Michigan (fig. 9A). The downward streamflow trends are consistent with neutral to downward trends in precipitation in this area (fig. $9 A$ ) and with neutral to upward trends in $T_{\text {min }}$ (fig. $9 B$ ), which have potential to increase evapotranspiration.

All 35 ECCC streamgages considered are generally east of Lake Huron (fig. 2), with 22 streamgages having statistically significant upward trends in annual streamflow and none with significant downward trends (fig. 9, table 1.2). Information regarding climate trends was not compiled for the Canadian part of the Great Lakes Basin; however, the consistency in upward streamflow trends resembles that for proximal streamgages in the U.S. part of the Great Lakes Basin.

The spatial distribution of seasonal streamflow trends for all streamgages (regardless of significance of trends), relative to seasonal climate trends (total precipitation, $T_{\min }$, and $T_{\max }$ ), is shown in figures 10-13. The seasonal climate trends for the U.S. part of the Great Lakes Basin are generally consistent with the broader national-scale trends, as indicated by trends in the surrounding buffer. The generally upward annual trends in $T_{\min }$ (fig. $9 B$ ) are driven primarily by the seasonal trends for April-June (fig. 12B) and July-September (fig. 13B).

The upward seasonal trends in precipitation east of Lake Michigan (figs. $10 \mathrm{~A}, 11 \mathrm{~A}, 12 \mathrm{~A}$, and $13 \mathrm{~A}$ ) generally are sparser (less dense spatial distribution) than the annual trends (fig. 9A). The densest spatial distribution in upward seasonal precipitation trends is for April-June (fig. 12A), and the spatial distribution of upward trends in the surrounding buffer extends substantially farther to the west than for the other seasons. Considering all USGS and ECCC streamgages regardless of trends in annual streamflow, the largest numbers of streamgages with statistically significant upward seasonal precipitation streamflow trends are for OctoberDecember and July-September (figs. 10 and 13, respectively; table 1.2), which may reflect a lag from the most pronounced upward trend in precipitation input of April-June (fig. 12A). 
$90^{\circ} \mathrm{W}$

$80^{\circ} \mathrm{W}$

$70^{\circ} \mathrm{W}$
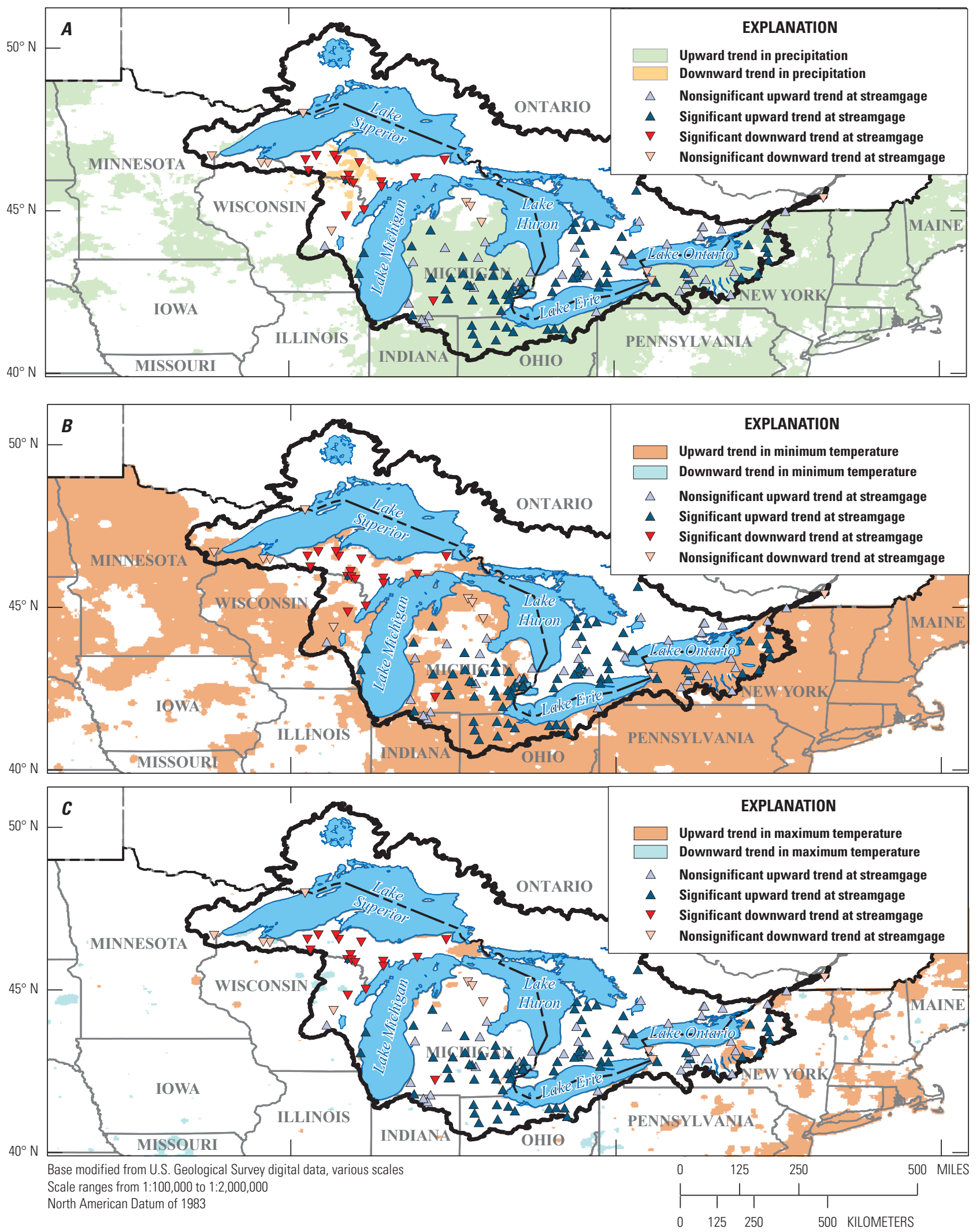

Figure 9. Trends in annual streamflow at streamgages in the Great Lakes Basin with statistically significant annual climate trends (precipitation and temperature) for 2.5-arc-minute Parameter-elevation Regressions on Independent Slopes Model (PRISM) grid cells within the United States for water years 1960-2015. $A$, total precipitation; $B$, monthly means of daily minimum air temperature; and $C$, monthly means of daily maximum air temperature. 
$90^{\circ} \mathrm{W}$

$80^{\circ} \mathrm{W}$
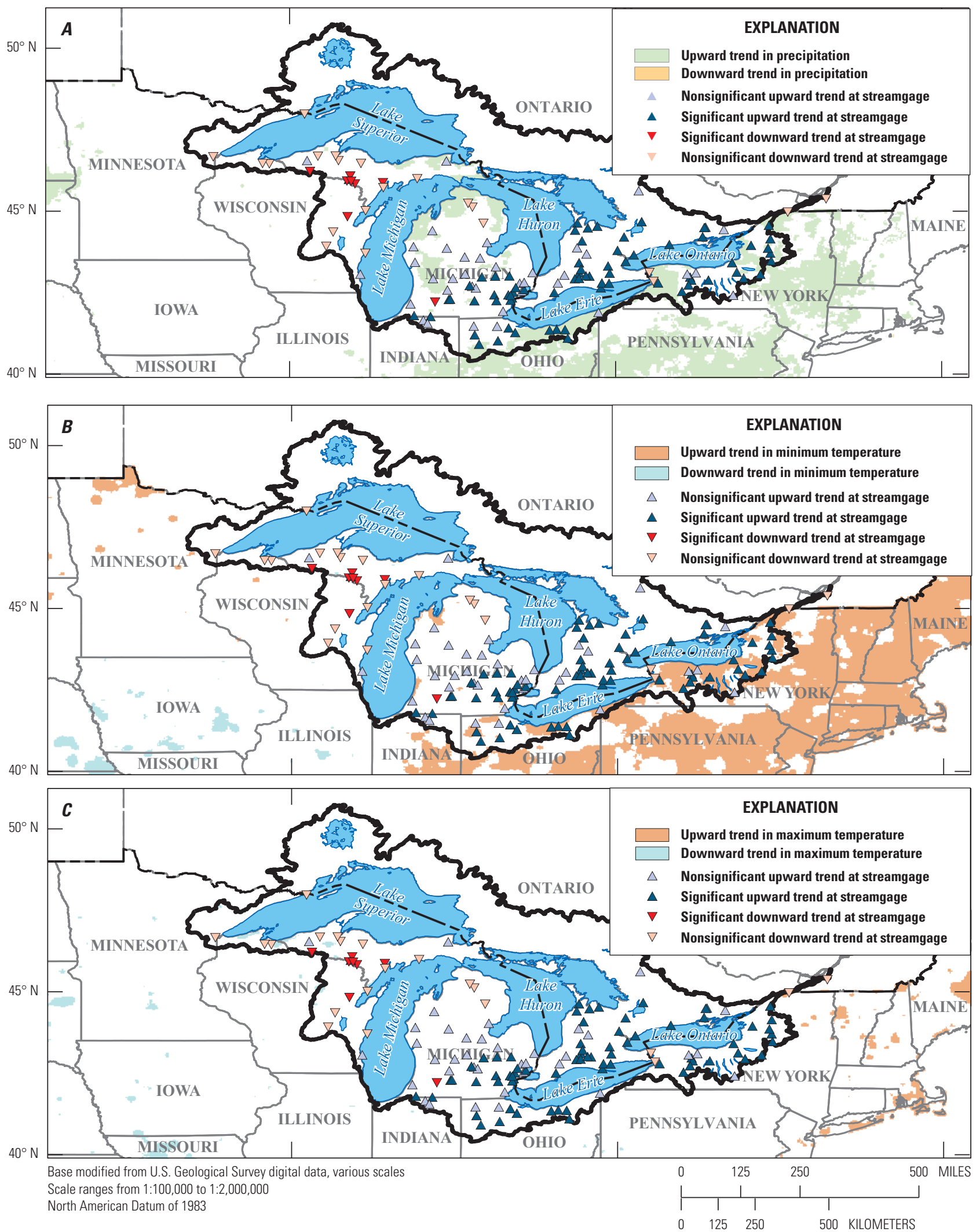

Figure 10. Seasonal (October-December) streamflow trends at streamgages in the Great Lakes Basin with statistically significant seasonal climate trends for 2.5-arc-minute Parameter-elevation Regressions on Independent Slopes Model (PRISM) grid cells within the United States for water years 1960-2015. A, total precipitation; $B$, monthly means of daily minimum air temperature; and $C$, monthly means of daily maximum air temperature. 
$90^{\circ} \mathrm{W}$

$80^{\circ} \mathrm{W}$

$70^{\circ} \mathrm{W}$
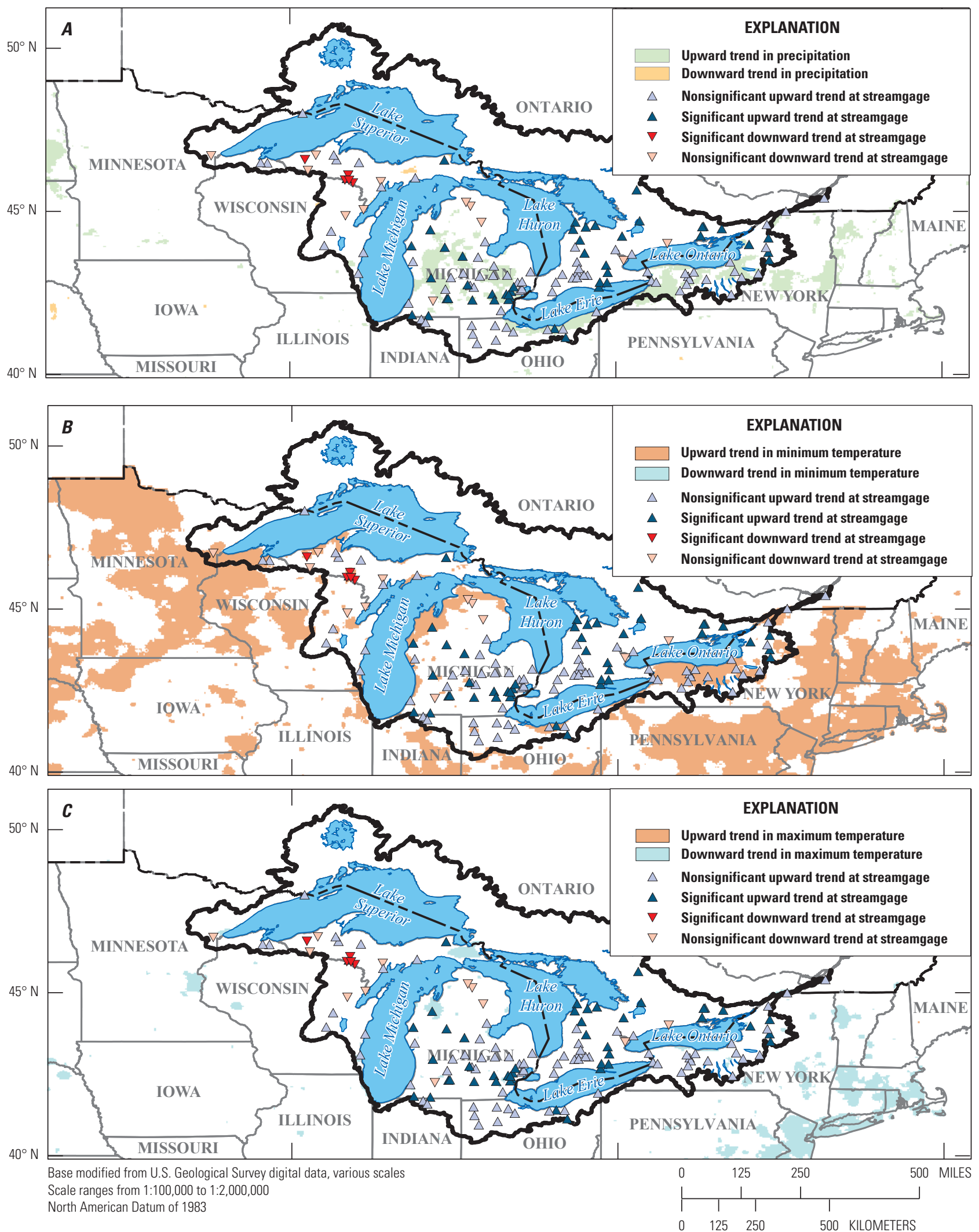

Figure 11. Seasonal (January-March) streamflow trends at streamgages in the Great Lakes Basin with statistically significant seasonal climate trends for 2.5-arc-minute Parameter-elevation Regressions on Independent Slopes Model (PRISM) grid cells within the United States for water years 1960-2015. $A$, total precipitation; $B$, monthly means of daily minimum air temperature; and $C$, monthly means of daily maximum air temperature. 
$90^{\circ} \mathrm{W}$

$80^{\circ} \mathrm{W}$

$70^{\circ} \mathrm{W}$
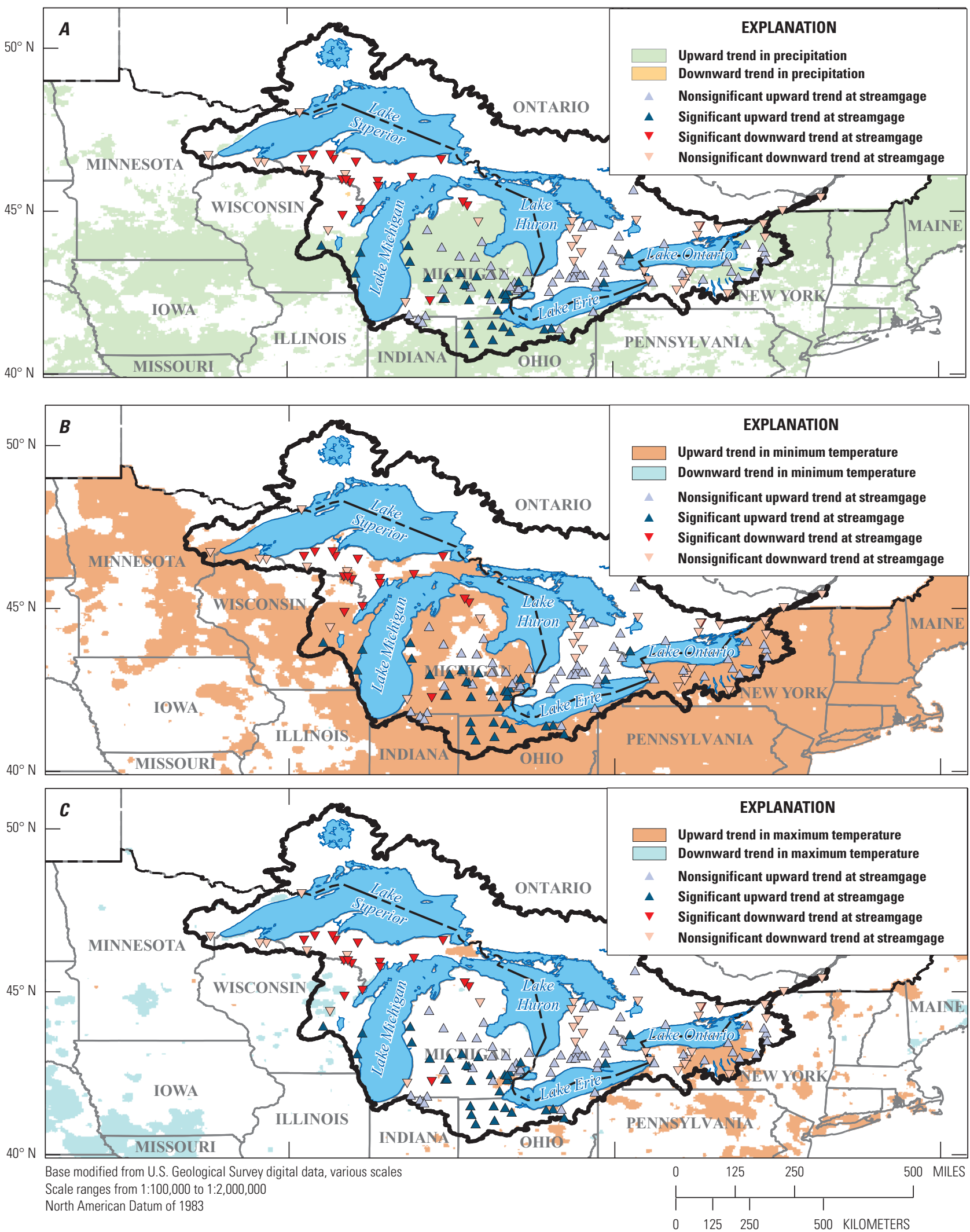

Figure 12. Seasonal (April-June) streamflow trends at streamgages in the Great Lakes Basin with statistically significant seasonal climate trends for 2.5-arc-minute Parameter-elevation Regressions on Independent Slopes Model (PRISM) grid cells within the United States for water years 1960-2015. $A$, total precipitation; $B$, monthly means of daily minimum air temperature; and $C$, monthly means of daily maximum air temperature. 
$90^{\circ} \mathrm{W}$

$80^{\circ} \mathrm{W}$

$70^{\circ} \mathrm{W}$
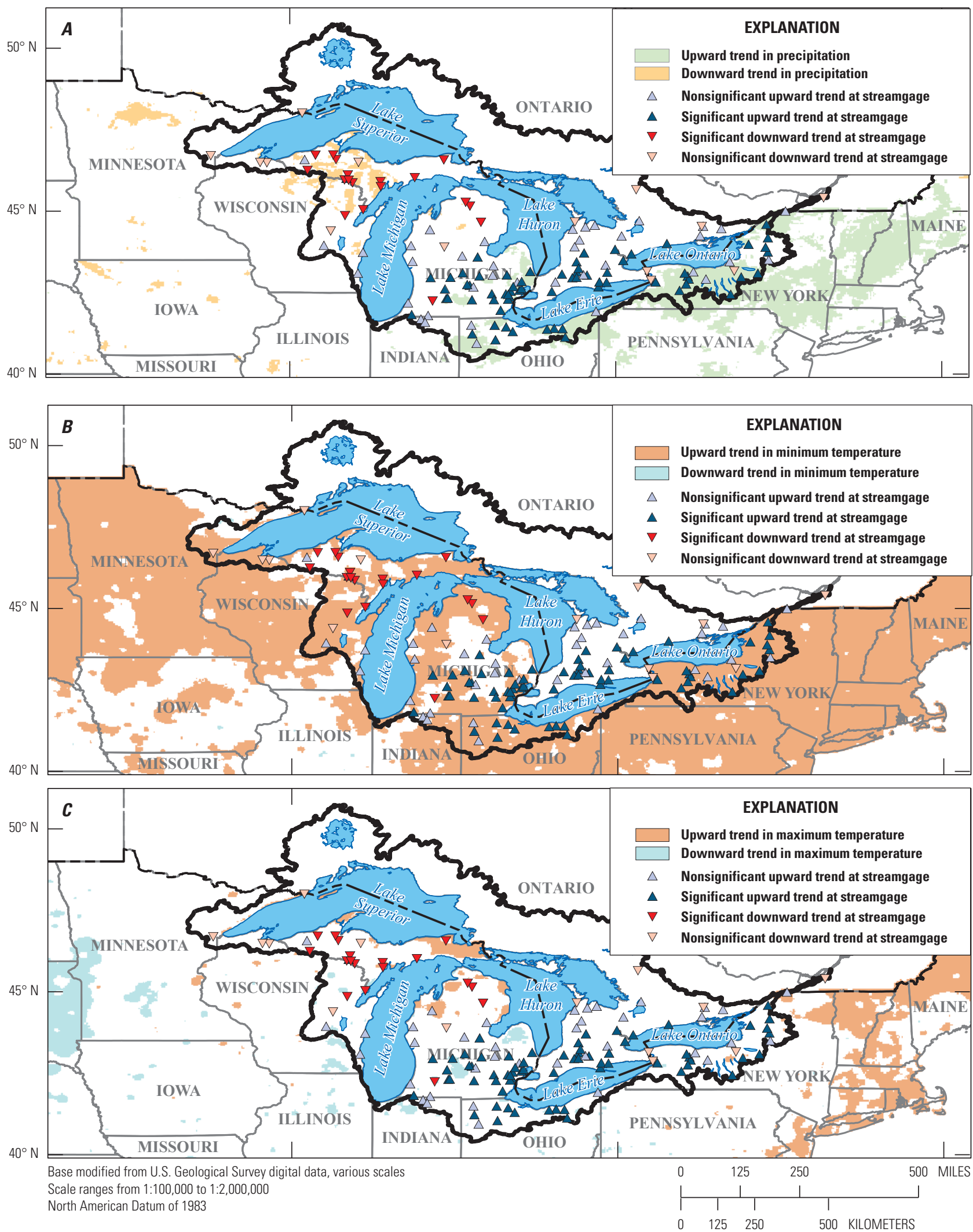

Figure 13. Seasonal (July-September) streamflow trends at streamgages in the Great Lakes Basin with statistically significant seasonal climate trends for 2.5-arc-minute Parameter-elevation Regressions on Independent Slopes Model (PRISM) grid cells within the United States for water years 1960-2015. $A$, total precipitation; $B$, monthly means of daily minimum air temperature; and $C$, monthly means of daily maximum air temperature. 
The seasonal trends in streamflow northwest of Lake Michigan are predominantly downward (figs. 10-13) and are consistent with the annual trends (fig. 9). The downward streamflow trends are especially prevalent for April-June and July-September (figs. 12 and 13, respectively; table 1.2). The spatial distribution of upward seasonal trends in $T_{\min }$ also is especially prevalent for April-June and July-September and extends broadly to the south and west for both seasons (figs. $12 B$ and 13B). Statistically significant upward trends in $T_{\max }$ are sparse within the U.S. part of the Great Lakes Basin for all seasons and are consistent with the broader nationalscale trends indicated outside of the basin.

Two streamgages are downstream from Lake Ontario on the St. Lawrence River (streamgage 04264331, map number 103 and streamgage 02OA016, map number 138). Neither streamgage had statistically significant annual or seasonal trends in streamflow (table 1.2), indicating neutral trends for the Great Lakes Basin for the study period.

\section{Lake-Level Trends}

Lake levels within the Great Lakes are important because of effects on shipping, recreational boating, water supply, hydropower generation, coastline erosion, and other factors critical to many large population centers (Neff and Nicholas, 2005). Lake levels for the Great Lakes are affected by numerous natural and human factors, and large volumes of scientific information regarding many factors have been assembled because of the major societal importance of the Great Lakes. The purpose of this section is to examine trends in lake levels and several primary factors affecting lake levels in the context of the analyses of trends in climate and streamflow presented in the preceding sections.

\section{Factors Affecting Lake Levels}

The factors that have the greatest effects on water levels in the Great Lakes are several major components of the water budget. A basic generic water budget equation for any hydrologic system is inflows $=$ outflows + change in storage . In this report, the only inflow components analyzed for each of the Great Lakes are (1) precipitation over each lake and (2) runoff from each contributing lake subbasin. Outflow components that are analyzed are (1) evaporation from each lake and (2) lake outflow. Outflow from each lake becomes inflow to the next lake downstream. Analyses of waterbudget components were based on data products obtained from the Great Lakes Environmental Research Laboratory monthly hydrometeorological database (Hunter and others, 2015) and the Great Lakes Dashboard Project (Smith and others, 2016). Storage changes may be large over relatively short timeframes but are considered minor relative to the 1960-2015 study period. Many variables that were considered minor were neglected, including groundwater inflow and outflow, diversions, and consumptive withdrawals (Neff and
Nicholas, 2005). Additional details regarding individual waterbudget components are presented in the following section "Information Regarding Water-Budget Components."

Neff and Nicholas (2005, p. 2) described the Great Lakes-Saint Lawrence System as consisting of "(1) Lakes Superior, Michigan, Huron, Erie, and Ontario; (2) their connecting channels, Saint Marys River, Saint Clair River, Lake Saint Clair, Detroit River, and Niagara River; and (3) the Saint Lawrence River, which carries the waters of the Great Lakes to the Atlantic Ocean. The system also includes several constructed canals and control structures that either interconnect Great Lakes or connect the Great Lakes to other river systems," plus two diversions into Lake Superior. Water levels for, and outflows from, Lake Ontario have been substantially affected by operations of several control structures since 1958 (Neff and Nicholas, 2005); however, effects of regulation on the other Great Lakes generally are relatively minor, with outflows fluctuating primarily in response to lake levels.

A profile of the Great Lakes System (fig. 14; Ohio Division of Water Resources, 2017) provides insights regarding lake depths and interconnections between the lakes. Fluctuations in Lakes Michigan and Huron generally are similar because the lakes are hydraulically connected at about the same elevation (Hunter and others, 2015; Neff and Nicholas, 2005). Outflows from Lakes Michigan and Huron are affected by many factors, including water levels in Lake Saint Clair and Lake Erie, regulating structures, wind setup and seiche (oscillations), ice floes and jams, frazil ice (also frequently called "anchor ice"), and summertime aquatic plant growth (Neff and Nicholas, 2005). Isostatic rebound, which is a gradual postglacial rising of the Earth's surface, also has complicated effects on water levels in the Great Lakes (Lenters, 2004; Neff and Nicholas, 2005).

Various other factors can affect water levels in the Great Lakes, but most factors can be considered minor, relative to the major water-budget components. For example, dredging of the Saint Clair River from 1880 to 1965 permanently lowered Lake Michigan and Lake Huron by 15.8 inches (in.) (International Joint Commission, 1999; Neff and Nicholas, 2005); however, the associated change in storage is considered negligible, relative to the 1960-2015 timeframe for this study.

\section{Information Regarding Water-Budget Components}

Major water-budget components for the Great Lakes (timeframe unspecified), as reported by Neff and Nicholas (2005), are shown in figure 15. Diversions into Lake Superior of about 5,580 cubic feet per second $\left(\mathrm{ft}^{3} / \mathrm{s}\right)$, which exceed diversions out of the Great Lakes Basin by about 60 percent (Neff and Nicholas, 2005), are shown in figure 15. A diversion out of Lake Michigan is included in figure 15, but minor diversions out of Lake Erie are excluded (Neff and Nicholas, 2005). 


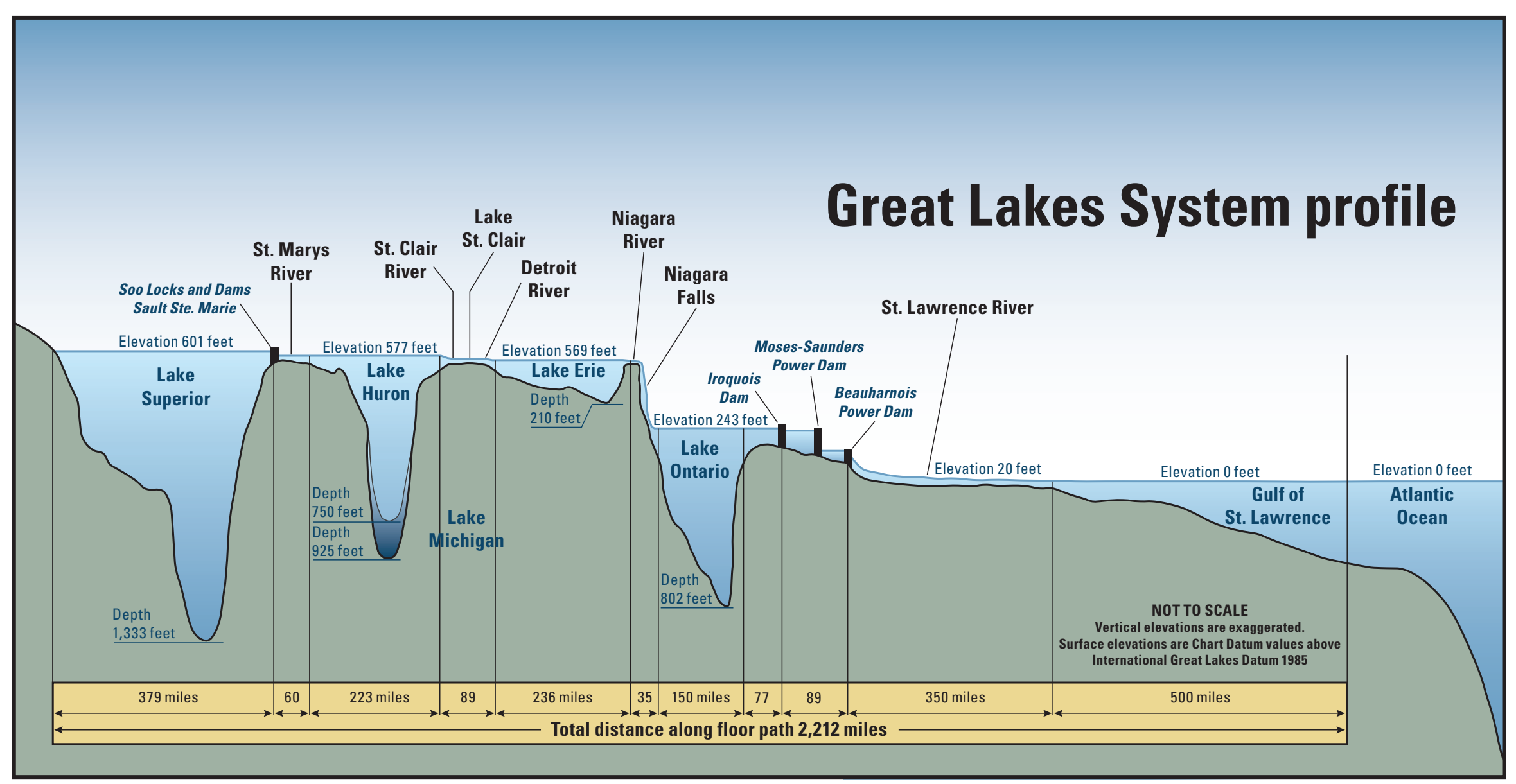

Frigure 14. Profile of the Great Lakes System (modified from Ohio Division of Water Resources, 2017, and Coordinating Committee on Great Lakes Basic Hydraulic and Hydrologic Data, 1992). 


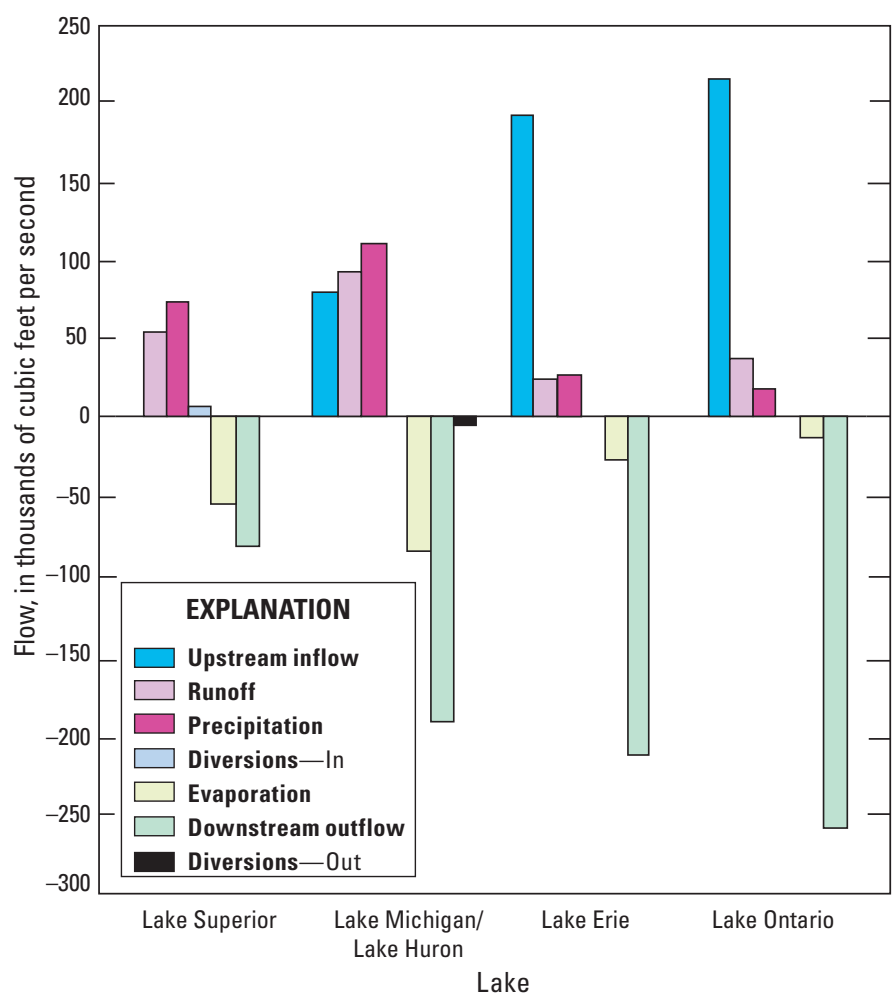

Figure 15. Major water-budget components for the Great Lakes (adapted from Neff and Nicholas, 2005). Positive values denote inflows, and negative values denote outflows from each lake.

The mean input from precipitation on each lake exceeds input from runoff for each of the Great Lakes, with a primary exception of Lake Ontario (fig. 15; Neff and Nicholas, 2005), for which the contributing drainage area is 3.4 times larger than the area of the lake (table 1). Lake Saint Clair (not shown on fig. 15) is between Lake Huron and Lake Erie (fig. 1) and often is included in computations of water budgets for the Great Lakes. The contributing drainage area for Lake Saint Clair is 14.2 times larger than the area of the lake (table 1); thus, the mean inflow component from runoff greatly exceeds that from overlake precipitation (Smith and others, 2016). Ratios of contributing drainage area to lake area are much smaller for the rest of the Great Lakes (table 1). Mean evaporation from each lake is largely proportional to lake area, and outflow from each lake becomes inflow to the next lake downstream.

Uncertainties are large for many water-budget components for the Great Lakes, especially regarding overlake precipitation, evaporation, and runoff. Neff and Nicholas (2005) provided the following general estimates of uncertainty ranges associated with monthly water-budget components as part of a comprehensive assessment of water-budget uncertainties for the Great Lakes. Overlake precipitation has the largest uncertainty, by percentage, and may range from about 15 to 45 percent. This uncertainty results primarily from (1) sparsity of precipitation gages that are representative of overlake precipitation, which can be much different from precipitation over the adjacent land masses, and (2) associated modeling inaccuracies. Uncertainty associated with estimated lake evaporation also is quite large (about 10 to 35 percent), with estimates derived by modeling, because there were no stations that measured lake evaporation within the Great Lakes Basin before about 2000 (Lenters and others, 2013). Uncertainties generally are relatively small where inflows are measured at streamgages; however, much of the Great Lakes Basin is ungaged and overall uncertainty in estimating runoff also is in the general range from about 15 to 35 percent. The smallest uncertainties are for lake outflows, which generally fall within ranges from about 5 to 15 percent and are estimated as no more than 2 percent from Lake Ontario (Neff and Nicholas, 2005). 
Table 1. Surface areas for Great Lakes and associated drainage basins (modified from Hunter and others, 2015).

\begin{tabular}{|c|c|c|c|c|c|}
\hline \multirow{2}{*}{ Lake } & \multicolumn{2}{|c|}{ Lake surface area } & \multicolumn{2}{|c|}{$\begin{array}{c}\text { Area of drainage basin } \\
\text { (excluding surface areas of } \\
\text { Great Lakes) }\end{array}$} & \multirow{2}{*}{$\begin{array}{c}\text { Ratio of } \\
\text { drainage basir } \\
\text { to lake }\end{array}$} \\
\hline & $\begin{array}{c}\text { Square } \\
\text { kilometers }^{\mathrm{a}}\end{array}$ & $\begin{array}{c}\text { Square } \\
\text { miles }\end{array}$ & $\begin{array}{c}\text { Square } \\
\text { kilometers }^{\mathrm{a}}\end{array}$ & $\begin{array}{c}\text { Square } \\
\text { miles }\end{array}$ & \\
\hline Superior & 82,100 & 31,700 & 128,000 & 49,400 & 1.6 \\
\hline Michigan & 57,800 & 22,300 & 118,000 & 45,600 & 2.0 \\
\hline Huron (excluding Georgian Bay) & 40,600 & 15,700 & 51,200 & 19,800 & 1.3 \\
\hline Georgian Bay & 19,000 & 7,300 & 82,800 & 32,000 & 4.4 \\
\hline Michigan, Huron, and Georgian Bay & 117,400 & 45,300 & 252,000 & 97,400 & 2.1 \\
\hline Saint Clair & 1,110 & 430 & 15,700 & 6,100 & 14.2 \\
\hline Erie & 25,700 & 9,900 & 61,000 & 23,600 & 2.4 \\
\hline Ontario & 19,000 & 7,300 & 64,000 & 24,700 & 3.4 \\
\hline Total & 245,310 & 94,600 & 520,700 & 201,200 & 2.1 \\
\hline
\end{tabular}

${ }^{\mathrm{a}}$ As reported by Hunter and others (2015).

${ }^{\mathrm{b} C o m b i n e d ~ a r e a s ~ f o r ~ L a k e ~ M i c h i g a n, ~ L a k e ~ H u r o n, ~ a n d ~ G e o r g i a n ~ B a y ~ a r e ~ s h o w n ~ i n ~ i t a l i c s ~ a n d ~ a r e ~ c o u n t e d ~ o n l y ~ o n c e ~ i n ~ t h e ~ t o t a l . ~}$

\section{Trends in Annual Lake Levels and Major Water- Budget Components}

The trends in climate and streamflow that were described in two preceding sections ("Climate Trends" and "Streamflow Trends") provide a useful context for comparisons with trends in lake levels and major water-budget components for the Great Lakes. Analyses of water-budget components were based on data products obtained from the Great Lakes Environmental Research Laboratory monthly hydrometeorological database (Hunter and others, 2015) and the Great Lakes Dashboard Project (Smith and others, 2016).

Trends in annual mean lake levels and annual major water-budget components for Lake Superior for 1960-2015 are shown in figure 16. A statistically significant downward trend in lake level that is driven primarily by a prolonged period of low lake levels during about 1998-2014 is indicated in figure $16 \mathrm{~A}$. A significant downward trend in outflow from Lake Superior (fig. 16B) corresponds to the lake-level trend because lake outflow is greatly affected by lake level. A nonsignificant downward trend in overlake precipitation, which is consistent with the trend of neutral to downward annual total precipitation in the area south of Lake Superior (fig. 9A), is indicated in figure $16 C$. The nonsignificance of this trend is greatly affected by two wet years in 2013 and 2014. A significant downward trend in runoff from the contributing drainage area also is indicated (fig. 16D), which is consistent with numerous streamgages south of Lake Superior with significant downward trends in annual streamflow (fig. 9). A significant upward trend in annual evaporation also is indicated (fig. 16E), which is consistent with the spatially distributed upward trends in annual minimum temperature shown in figure $9 B$.

Regarding trends in runoff into Lake Superior, the first 10 USGS streamgages considered in analyzing streamflow trends are within the Lake Superior subbasin (table 1.1; fig. 1; map numbers 1-10). Of these 10 streamgages, 6 have statistically significant downward trends in annual streamflow (table 1.2; fig. 9) and the other 4 have downward trends that are not significant. Of the 10 seasonal streamflow trends for July-September, 9 are downward (only 5 are significant), and for April-June, 10 are downward (only 5 are significant).

Trends in annual mean lake levels and annual major water-budget components for 1960-2015 for Lakes Michigan and Huron combined, Lake Saint Clair, Lake Erie, and Lake Ontario, respectively, are shown in figures 17-20. Waterbudget components for Lakes Michigan and Huron are combined because the lakes are hydraulically connected at the same elevation (Hunter and others, 2015; Neff and Nicholas, 2005). Lake Saint Clair is included because it is along the Great Lakes flow system between Lake Huron and Lake Erie (fig. 1) and commonly is included in computations of water budgets for the Great Lakes (Hunter and others, 2015).

Lakes Michigan and Huron, Lake Saint Clair, and Lake Erie have all experienced prolonged periods of low lake levels, similar to Lake Superior, during about 1998-2014 (figs. 17A, 18A, and 19A); however, a statistically significant downward trend for WYs 1960-2015 is indicated only for Lakes Michigan and Huron (fig. 17A). These lakes also had periods of low lake levels before about 1968, when minimum lake levels for some years were lower than during 1998-2014. The pattern of pre-1968 low lake levels extended downstream into Lake Ontario (fig. 20A); however, lake levels for Lake Ontario during 1998-2014 were near the mean and may have been affected to some extent by regulation. The significant downward trend of outflow from Lake Superior (fig. 16B) extended downstream into Lakes Michigan and Huron (fig. 17B); however, trends in outflow from the next three lakes downstream (Lakes Saint Clair, Erie, and Ontario) were not significant (figs. 18B, 19B, and 20B, respectively). 
A. Annual mean of lake elevation [probability value $(p$-value $)=0.0017$, Kendall's tau $(\tau)=-0.2891$ ]
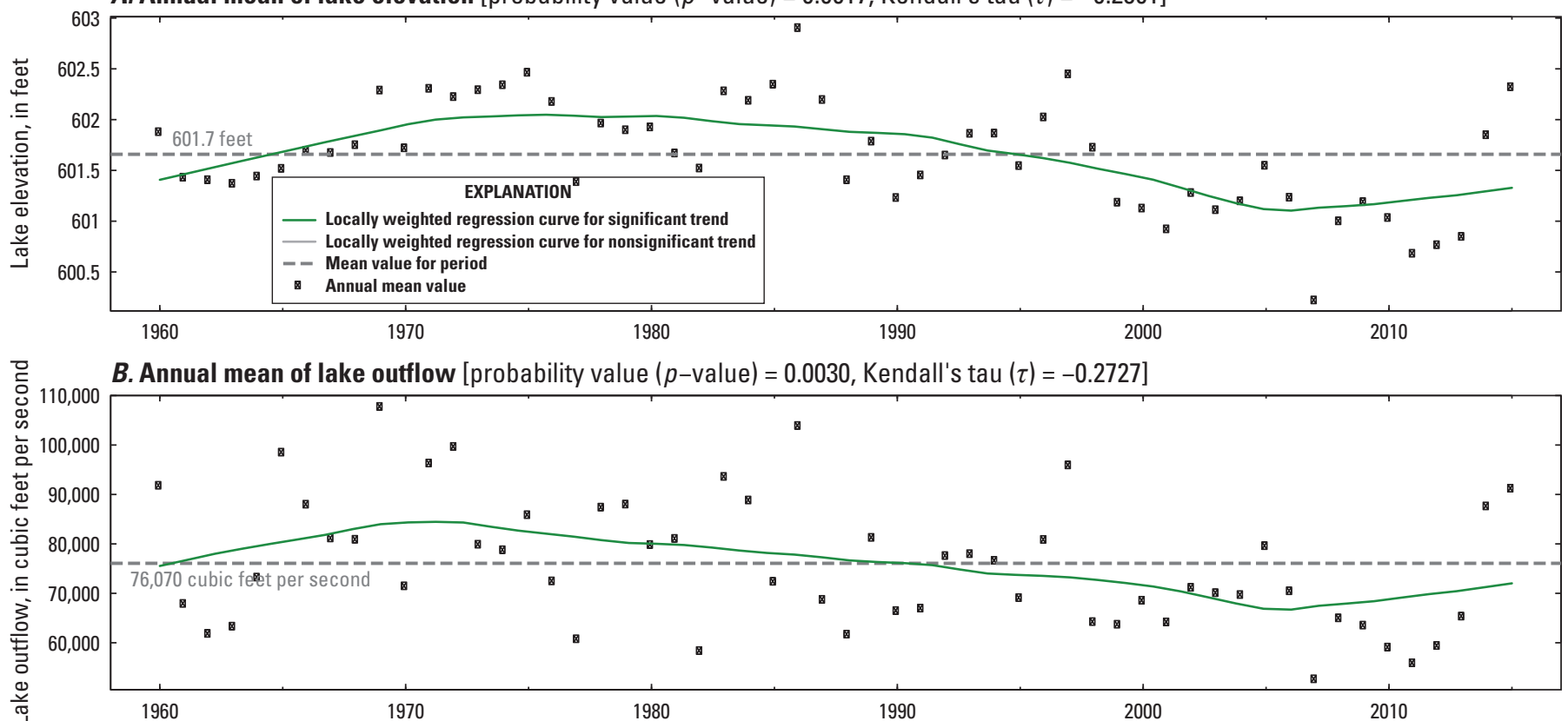

C. Annual total of monthly overlake precipitation [probability value $(p$-value $)=0.2988$, Kendall's tau $(\tau)=-0.0955$ ]

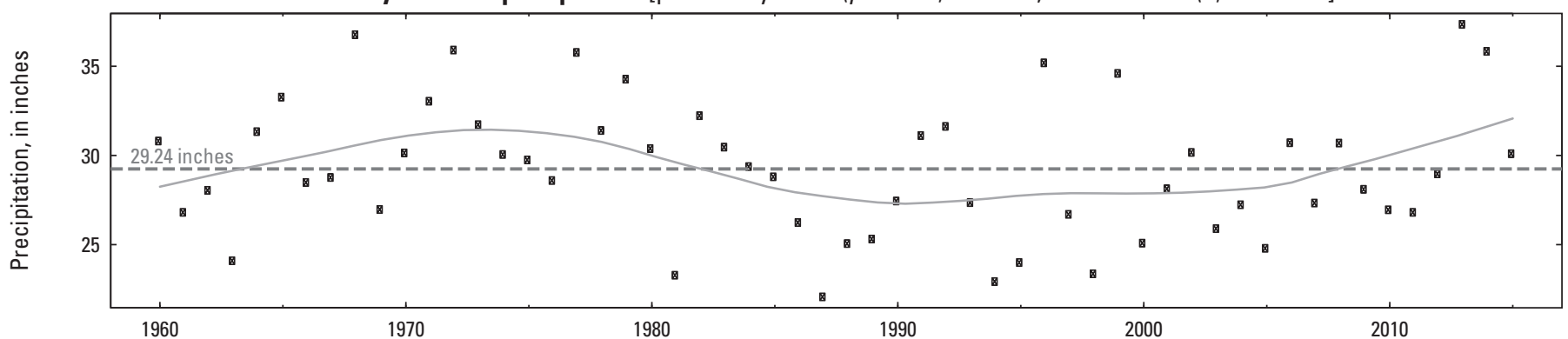

D. Annual total of monthly runoff [probability value $(p$-value $)=0.0169$, Kendall's tau $(\tau)=-0.2195$ ]

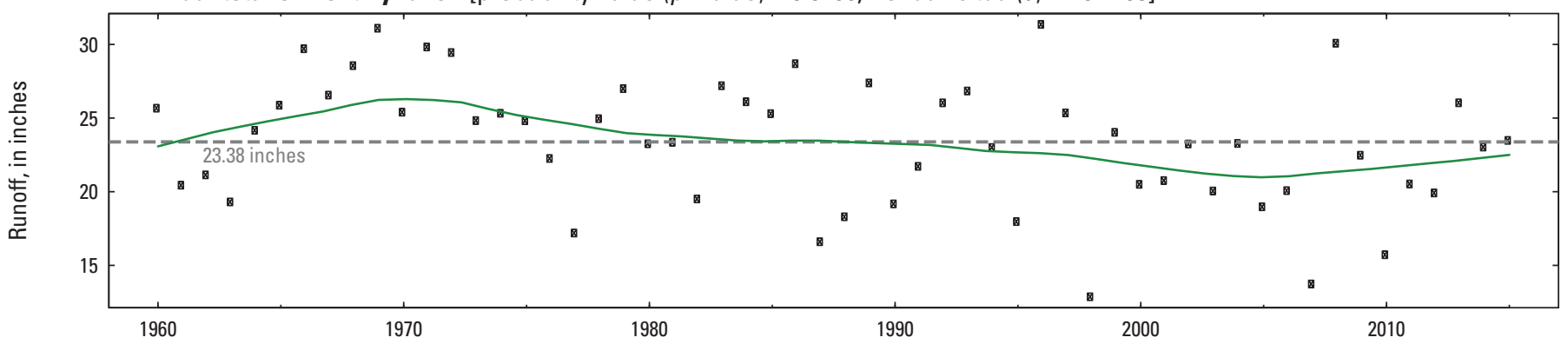

E. Annual total of monthly overlake evaporation [probability value $(p$-value $)=0.0193$, Kendall's tau $(\tau)=0.2150$ ]

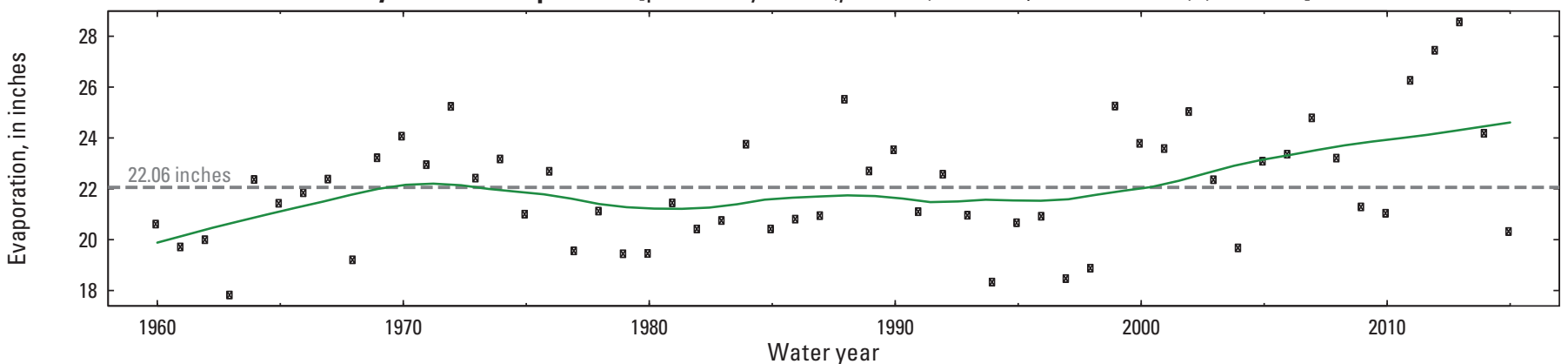

Figure 16. Annual trends in lake level and major water-budget components for Lake Superior, water years 1960-2015. $A$, annual mean of lake elevation; $B$, annual mean of lake outflow; $C$, annual total of monthly overlake precipitation; $D$, annual total of monthly runoff; and $E$, annual total of monthly overlake evaporation. 
A. Annual mean of lake elevation [probability value $(p$-value $)=0.0233$, Kendall's tau $(\tau)=-0.2085$ ]
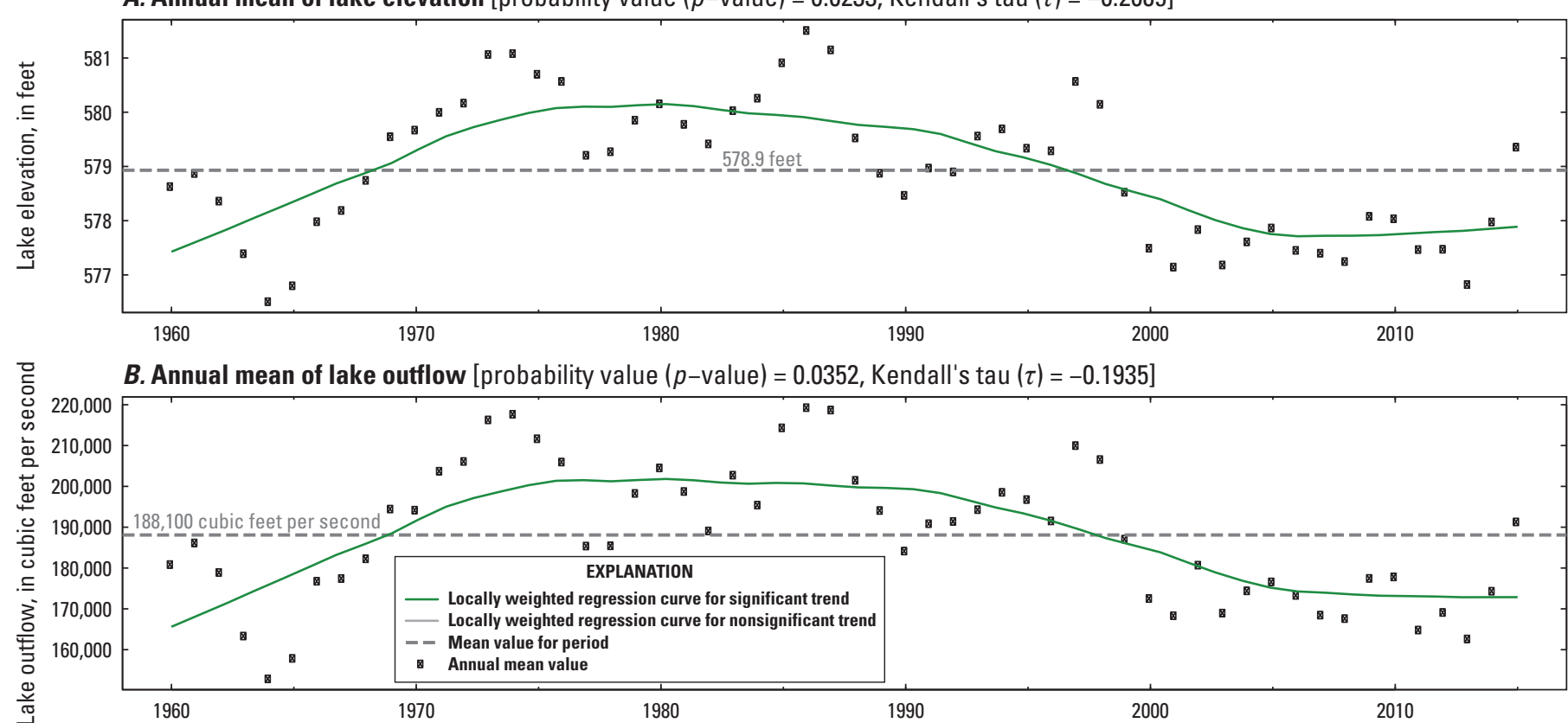

C. Annual total of monthly overlake precipitation [probability value $(p$-value $)=0.6208$, Kendall's tau $(\tau)=0.0455$ ]

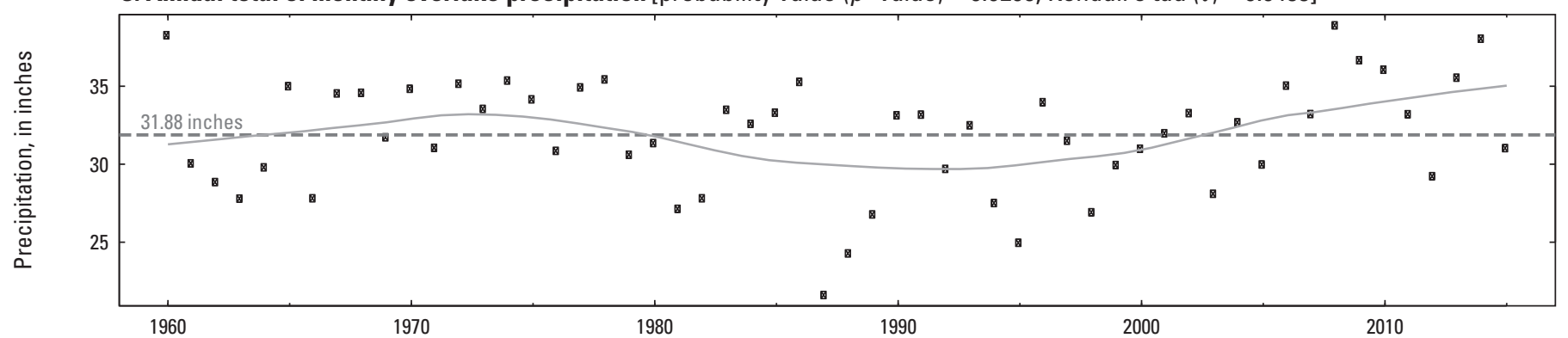

D. Annual total of monthly runoff [probability value $(p$-value $)=0.6923$, Kendall's tau $(\tau)=0.0364$ ]

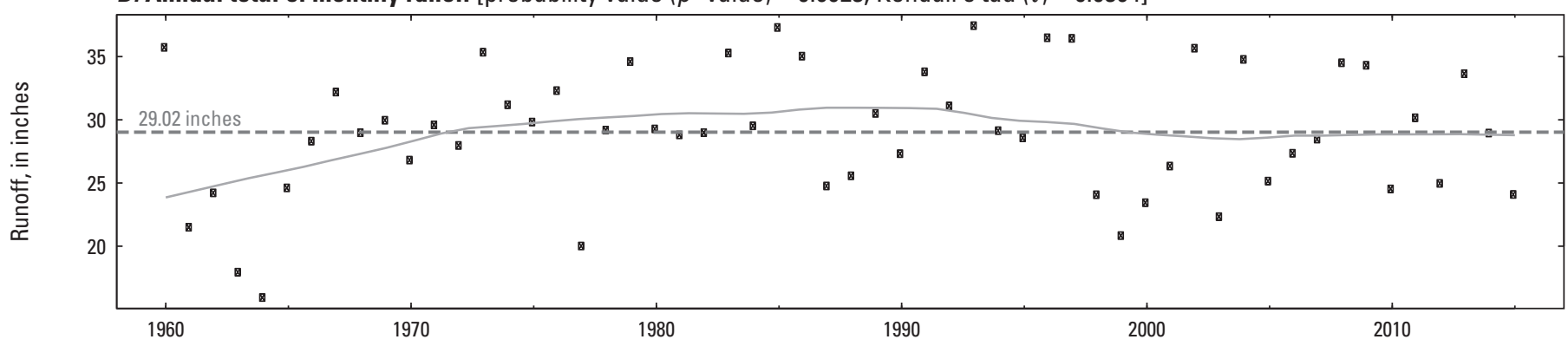

E. Annual total of monthly overlake evaporation [probability value $(p$-value $)=0.0749$, Kendall's tau $(\tau)=0.1636$ ]

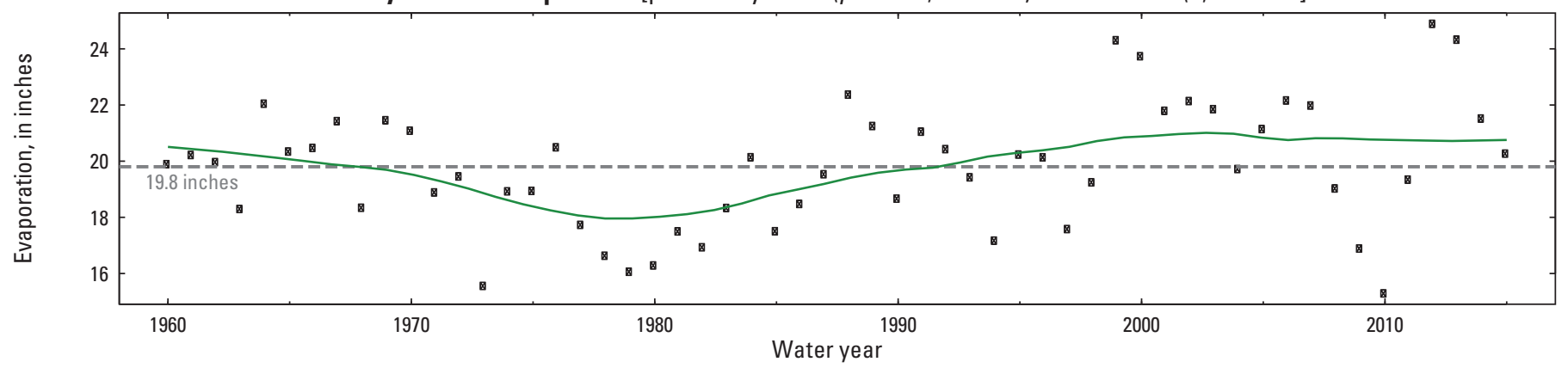

Figure 17. Annual trends in lake level and major water-budget components for Lakes Michigan and Huron, water years 1960-2015. $A$, annual mean of lake elevation; $B$, annual mean of lake outflow; $C$, annual total of monthly overlake precipitation; $D$, annual total of monthly runoff; and $E$, annual total of monthly overlake evaporation. 
A. Annual mean of lake elevation [probability value $(p$-value $)=0.2859$, Kendall's tau $(\tau)=-0.0981$ ]
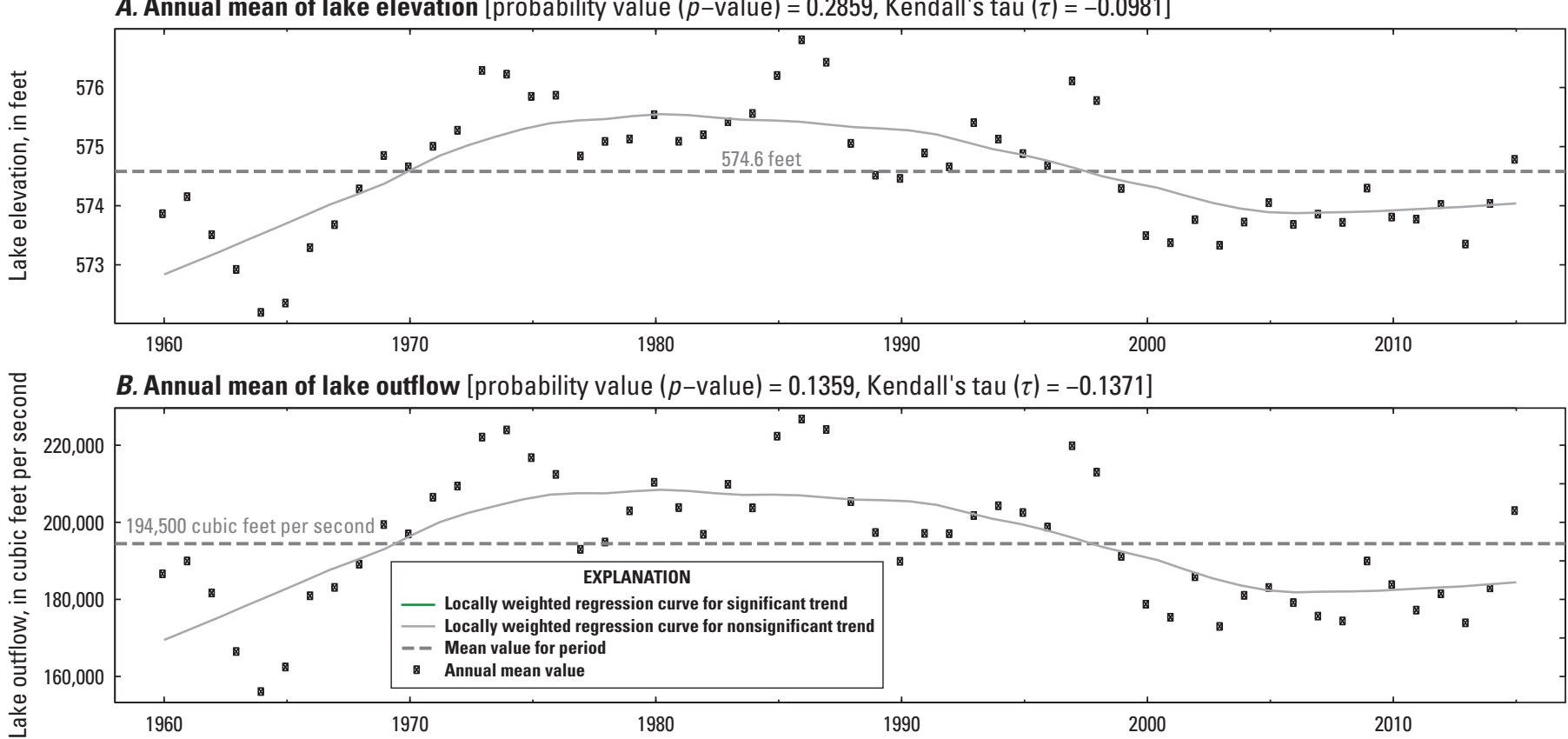

C. Annual total of monthly overlake precipitation [probability value $(p$-value $)=0.0212$, Kendall's tau $(\tau)=0.2117$ ]

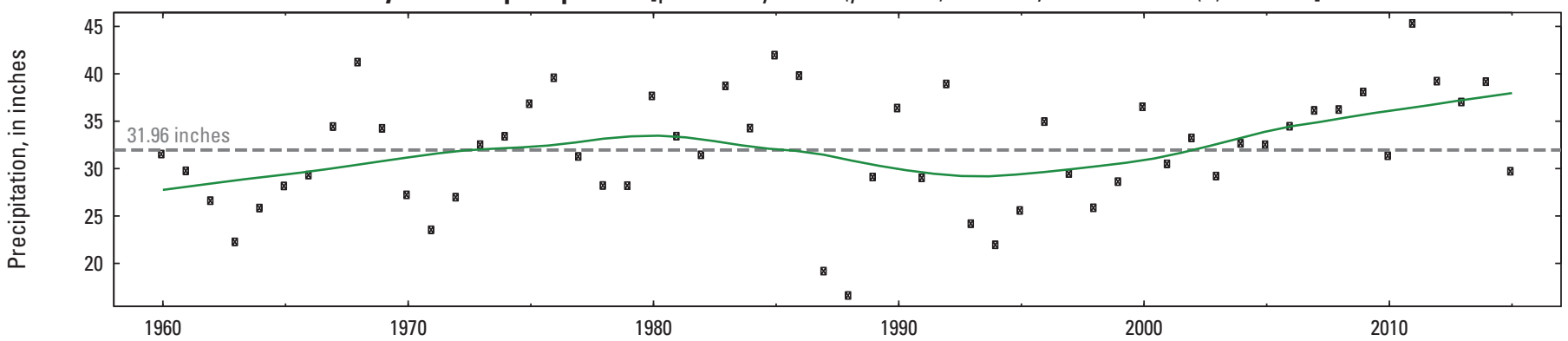

D. Annual total of monthly runoff [probability value $(p$-value $)=0.0390$, Kendall's tau $(\tau)=0.1896$ ]

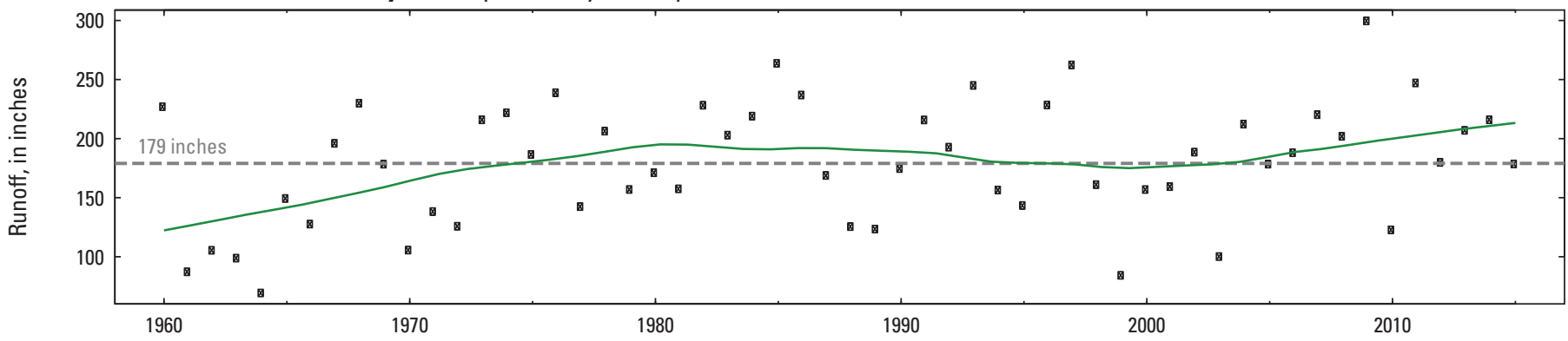

E. Annual total of monthly overlake evaporation [probability value $(p$-value $)=0.5019$, Kendall's tau $(\tau)=-0.0617$ ]

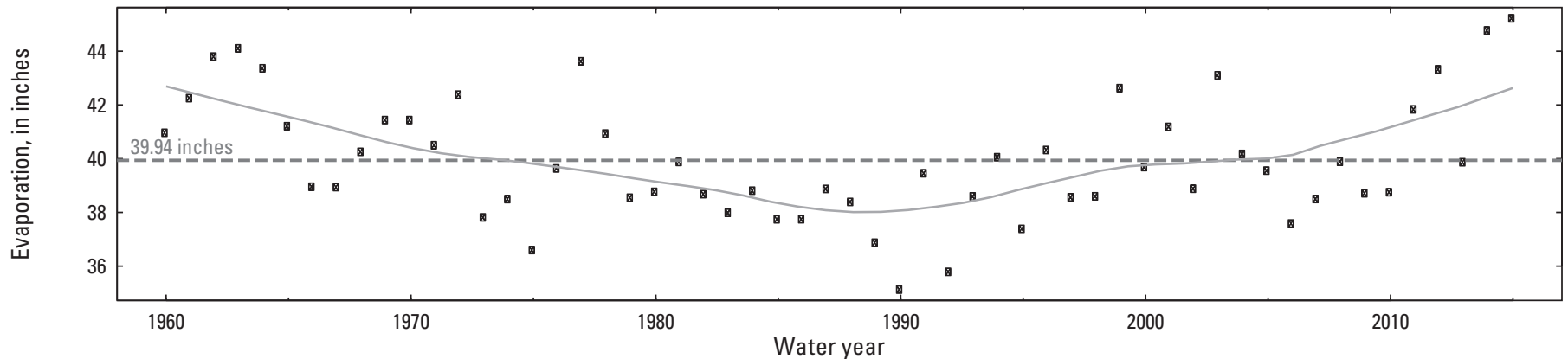

Figure 18. Annual trends in lake level and major water-budget components for Lake Saint Clair, water years 1960-2015. $A$, annual mean of lake elevation; $B$, annual mean of lake outflow; $C$, annual total of monthly overlake precipitation; $D$, annual total of monthly runoff; and $E$, annual total of monthly overlake evaporation. 
A. Annual mean of lake elevation [probability value $(p$-value $)=0.6108$, Kendall's tau $(\tau)=-0.0468$ ]
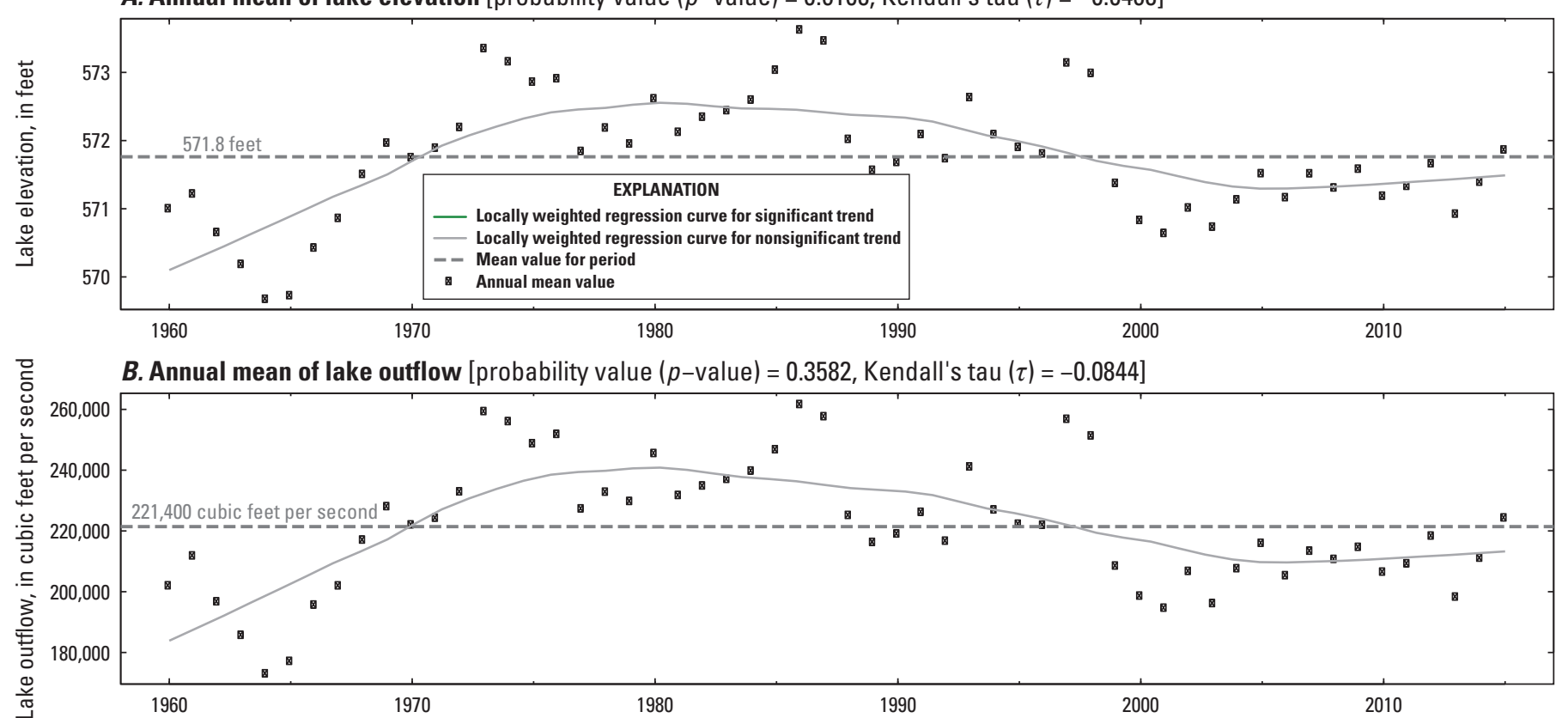

C. Annual total of monthly overlake precipitation [probability value $(p$-value $)=0.3657$, Kendall's tau $(\tau)=0.0831$ ]

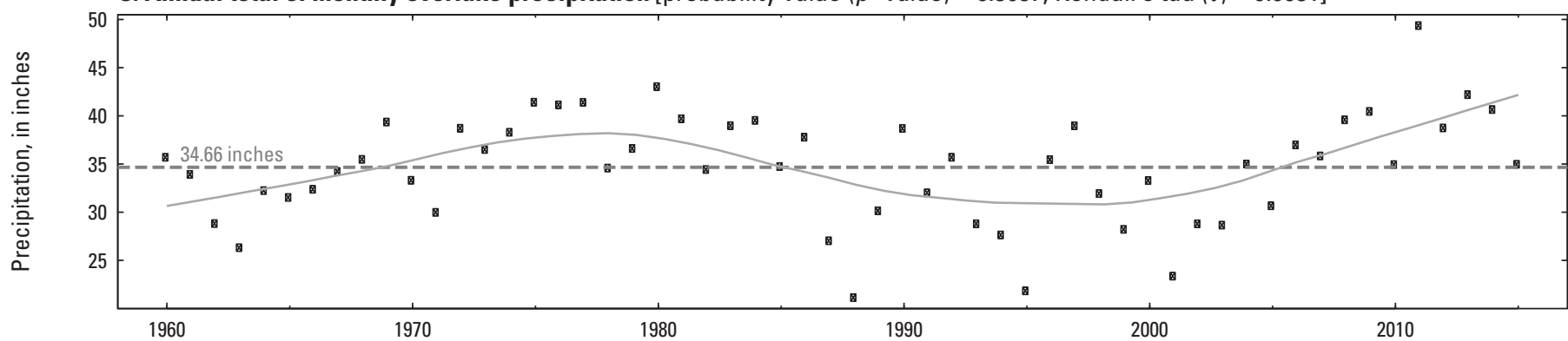

D. Annual total of monthly runoff [probability value $(p$-value $)=0.0237$, Kendall's tau $(\tau)=0.2078$ ]

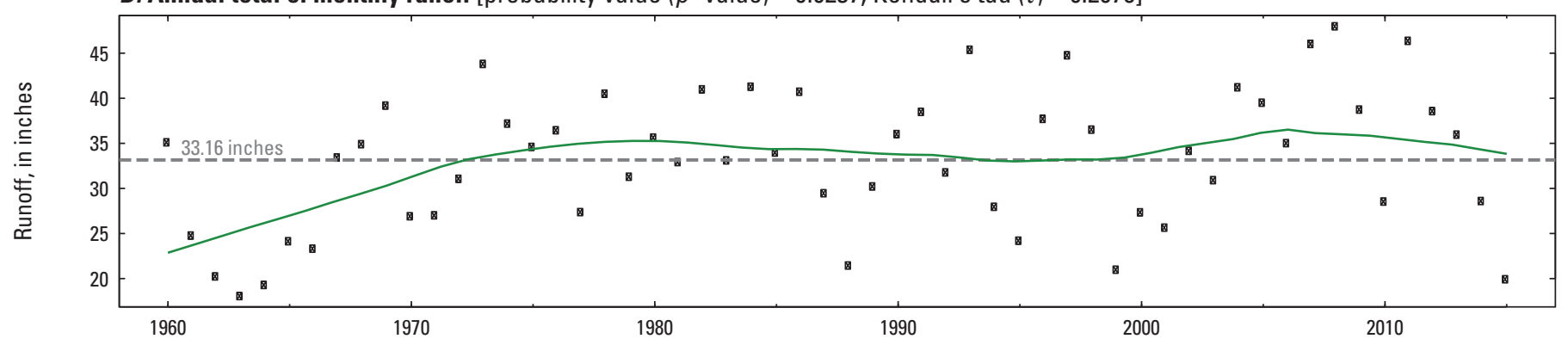

E. Annual total of monthly overlake evaporation [probability value $(p$-value $)=0.0002$, Kendall's tau $(\tau)=0.3390$ ]

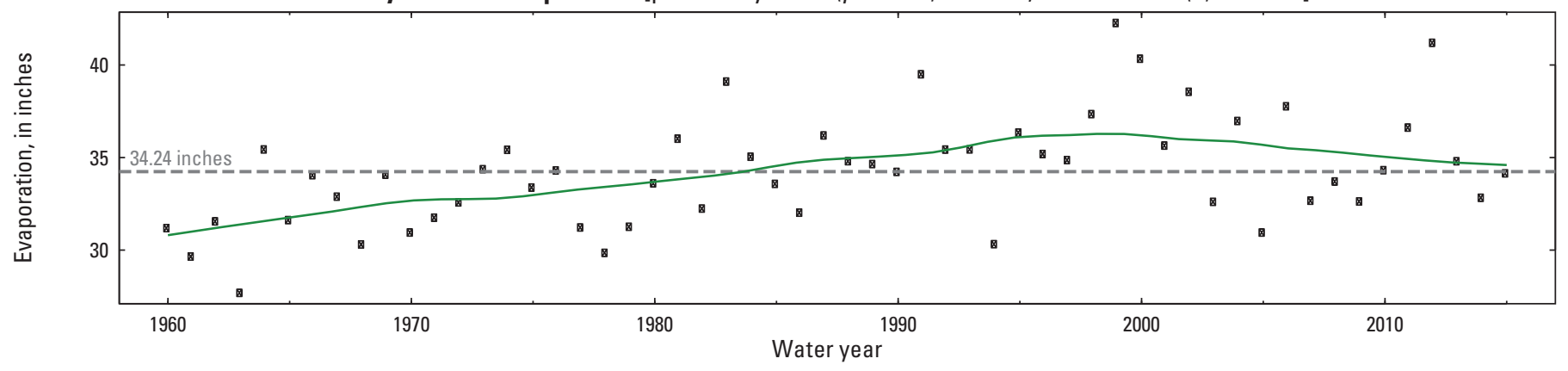

Figure 19. Annual trends in lake level and major water-budget components for Lake Erie, water years 1960-2015. $A$, annual mean of lake elevation; $B$, annual mean of lake outflow; $C$, annual total of monthly overlake precipitation; $D$, annual total of monthly runoff; and $E$, annual total of monthly overlake evaporation. 
A. Annual mean of lake elevation [probability value $(p-$ value $)=0.4204$, Kendall's tau $(\tau)=0.0741$ ]
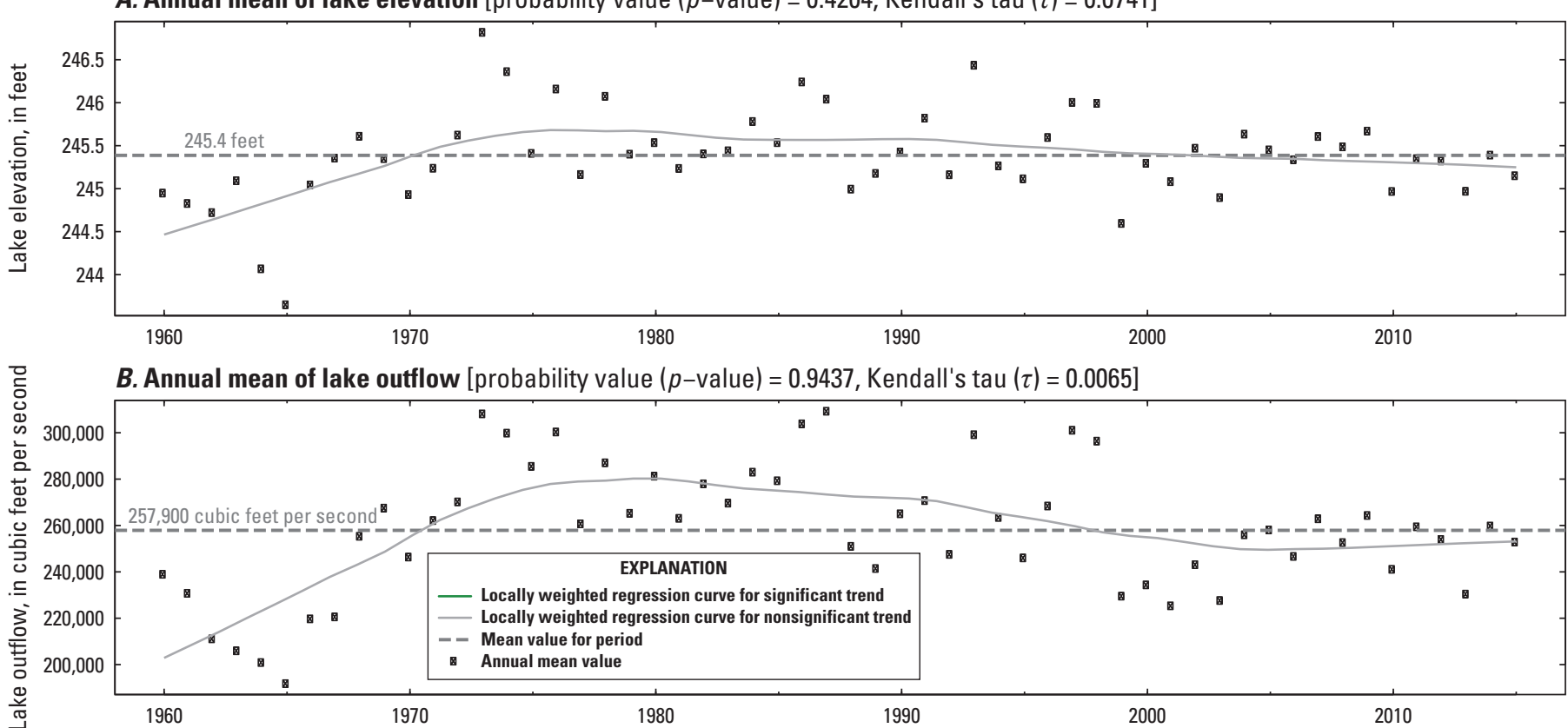

C. Annual total of monthly overlake precipitation [probability value $(p$-value $)=0.0404$, Kendall's tau $(\tau)=0.1883$ ]

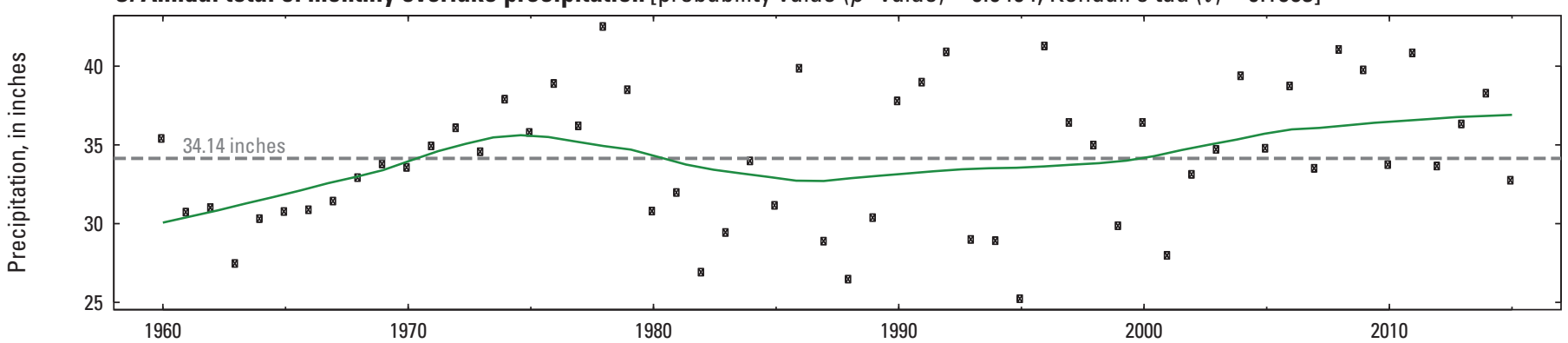

D. Annual total of monthly runoff [probability value $(p$-value $)=0.0749$, Kendall's tau $(\tau)=0.1636$ ]

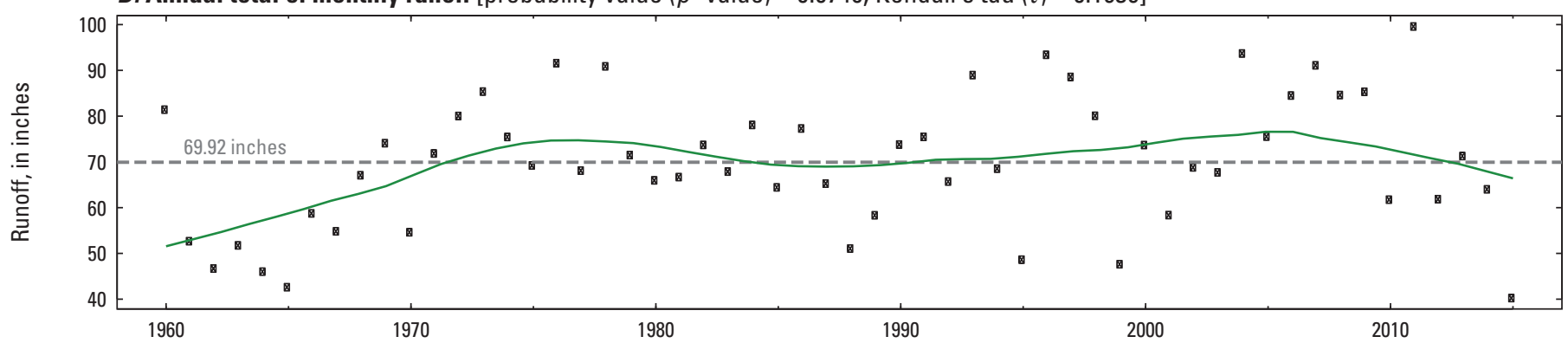

E. Annual total of monthly overlake evaporation [probability value $(p$-value $)=0.0704$, Kendall's tau $(\tau)=0.1662$ ]

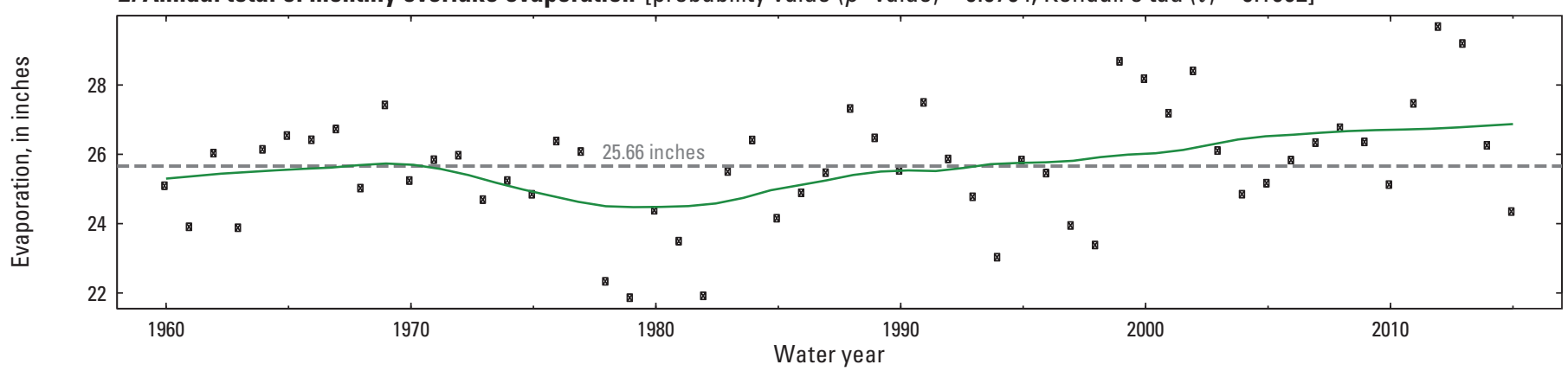

Figure 20. Annual trends in lake level and major water-budget components for Lake Ontario, water years 1960-2015. $A$, annual mean of lake elevation; $B$, annual mean of lake outflow; $C$, annual total of monthly overlake precipitation; $D$, annual total of monthly runoff; and $E$, annual total of monthly overlake evaporation. 
Trends in annual water-budget components for the Great Lakes Basin for 1960-2015 are shown in figure 21. A lake-level graph, which cannot be plotted for the basin, is not included in figure 21. The mean annual outflow of $257,900 \mathrm{ft}^{3} / \mathrm{s}$ from the basin (fig. $21 A$ ) is identical to the mean annual outflow from Lake Ontario (fig. 20B), so the nonsignificant outflow trend statistics $(p$-value $=0.9437$, $\tau=0.0065$ ) are identical for both. Trends for the basin are neutral for annual precipitation (fig. $21 B$ ) and the annual total of monthly runoff (fig. 21C); however, the annual total of monthly lake evaporation has a significant upward trend (fig. 21D). Statistically significant upward trends in annual evaporation are nearly ubiquitous for the individual lakes, with Lake Saint Clair being the lone exception (fig. 18E). The upward trends in evaporation are consistent with the spatial distribution of upward trends in annual $T_{\min }$ shown in figure $9 B$.

Relative flow contributions to Great Lakes outflow for major water-budget components, by lake, for 1960-2015 are summarized in table 2. Annual overlake total precipitation ranges from about 29 in. for Lake Superior to more than 34 in. for Lakes Erie and Ontario. Lakes Superior, Michigan, and Huron collectively contribute about 73 percent of the total outflow from the Great Lakes Basin. Lake evaporation varies substantially among the lakes and is driven by many complex factors (Hunter and others, 2015; Lenters and others, 2013).

The sum of runoff from the drainage basin and overlake precipitation, less overlake evaporation, composes a variable called net basin supply (NBS; Hunter and others, 2015; Neff and Nicholas, 2005). Annual NBS, by lake, is summarized in table 2, and trends in annual NBS for the individual Great Lakes and for the Great Lakes Basin are shown in figure 22. A significant downward trend in NBS is indicated for Lake Superior (fig. 22A), which is consistent with the significant downward trend for runoff (fig. 16D) and with the significant upward trend for evaporation (fig. 16E) that contributed to a significant downward trend for lake outflow (fig. 16B). Significant upward NBS trends for Lakes Saint Clair and Ontario (figs. $22 C$ and $22 E$, respectively) offset the downward trend for Lake Superior and combine with nonsignificant NBS trends for Lakes Michigan and Huron (fig. 22B) and Lake Erie (fig. 22D) to produce a nonsignificant and in effect neutral NBS trend ( $p$-value $=0.8050, \tau=0.0236$ ) for the entire Great Lakes Basin (fig. 22F).

\section{Monthly Lake Levels and Water-Budget Components}

Examination of monthly mean lake levels for 1960-2015 for the Great Lakes (figs. 23-27) provides insights regarding fluctuations in lake levels and driving factors. The monthly lake-level patterns for Lake Superior and Lakes Michigan and Huron (figs. 23 and 24, respectively) provide a much different perspective than the annual lake-level patterns (figs. 16 and 17). The persistence of above- or below-mean lake levels is readily apparent for Lakes Michigan and Huron (fig. 24), where the range of intra-annual variability excludes the 1960-2015 mean for most years. In contrast, the 1960-2015 mean for Lake Superior falls within the range of intra-annual variability for most years (fig. 23). The total amplitude of monthly variability for 1960-2015 is much less for Lake Superior (less than 4 feet [ft]) than for Lakes Michigan and Huron (more than $6 \mathrm{ft}$ ), which may be driven largely by hydraulic conditions at the outlets. The persistence of aboveor below-mean lake levels also is readily apparent for Lakes Saint Clair and Erie, where total amplitudes of monthly variability for 1960-2015 also are about $6 \mathrm{ft}$.

A predictable pattern is noted for Lake Superior lake levels (fig. 23); the minimum for each WY usually occurs during or near March (only occasionally for February or April), and the annual maximum most commonly occurs during or near September or October. When an October lake level is in a period of substantial decline, potential for an ensuing short-term period of below-mean lake levels is enhanced. An initial example is October of WY 1961, for which lake levels had declined since June and July and which became the first year of a 5-year period of below-mean annual lake levels. The corresponding below-mean outflows from Lake Superior (fig. 16B) likely were a contributing factor for a corresponding period of low lake levels that ensued downstream throughout the remainder of the Great Lakes System (figs. 24-27).

September of WY 1996 was the highest lake level in Lake Superior in about 10 years (fig. 23); however, the lake level dropped substantially in October (WY 1997). The ensuing years through WY 2013 were dominated by generally below-mean lake levels and October lake levels already in substantial decline. Only 3 years during this period did not have a decline in October lake levels (WYs 2003, 2005, and 2008). Below-mean outflows from Lake Superior during this period (fig. 16B) were again a factor in driving generally low lake levels that ensued downstream through Lakes Michigan and Huron, Lake Saint Clair, and Lake Erie; figs. 24-26, respectively). It should be noted that substantially declining lake levels before October do not necessarily indicate increased potential for below-mean lake levels in future years for Lake Superior, which instead depends on future hydroclimatic conditions. Several examples of this converse condition are included in figure 23, most notable of which may be a declining condition at the start of WY 1968, when the lake level fell to about $600.8 \mathrm{ft}$ in March but rose to almost $603 \mathrm{ft}$ by the following October.

Downstream from Lake Superior, monthly lake levels have sawtooth patterns that somewhat resemble those for Lake Superior (figs. 23-27) but with decreased predictability in timing. For Lakes Michigan and Huron (fig. 24), the annual minimum lake level occurred more often in February than in March, and annual minima were recorded in 5 other months. The annual maximum lake level typically occurred much earlier than for Lake Superior, with more annual maxima recorded during June and July than during August through October combined. 
A. Annual mean of lake outflow [probability value $(p$-value $)=0.9437$, Kendall's tau $(\tau)=0.0065$ ]

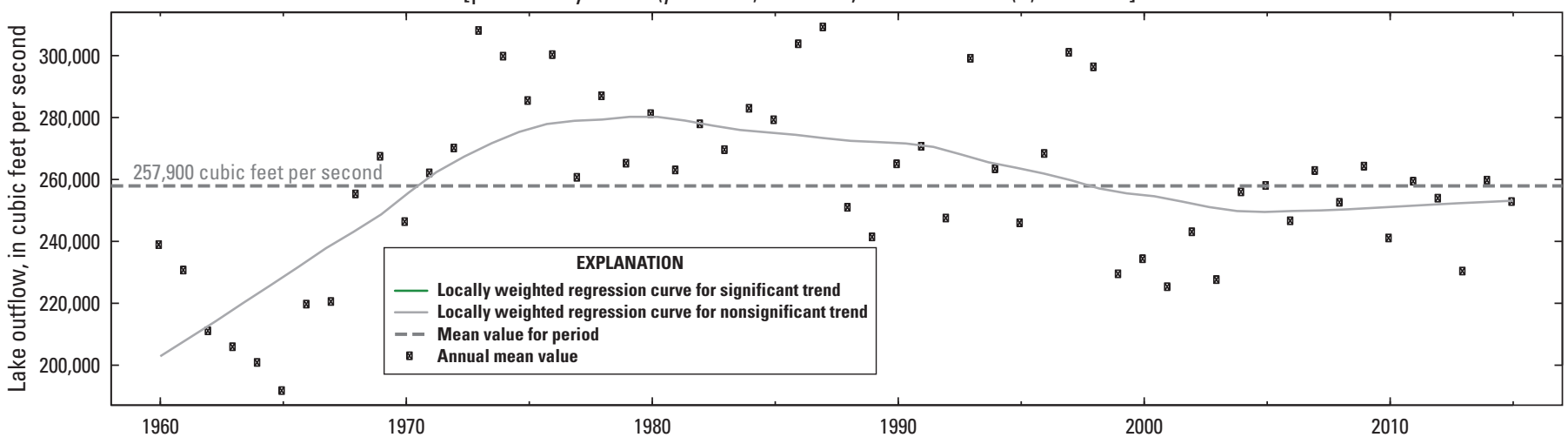

B. Annual total of monthly overlake precipitation [probability value $(p$-value $)=0.9212$, Kendall's tau $(\tau)=-0.0091$ ]

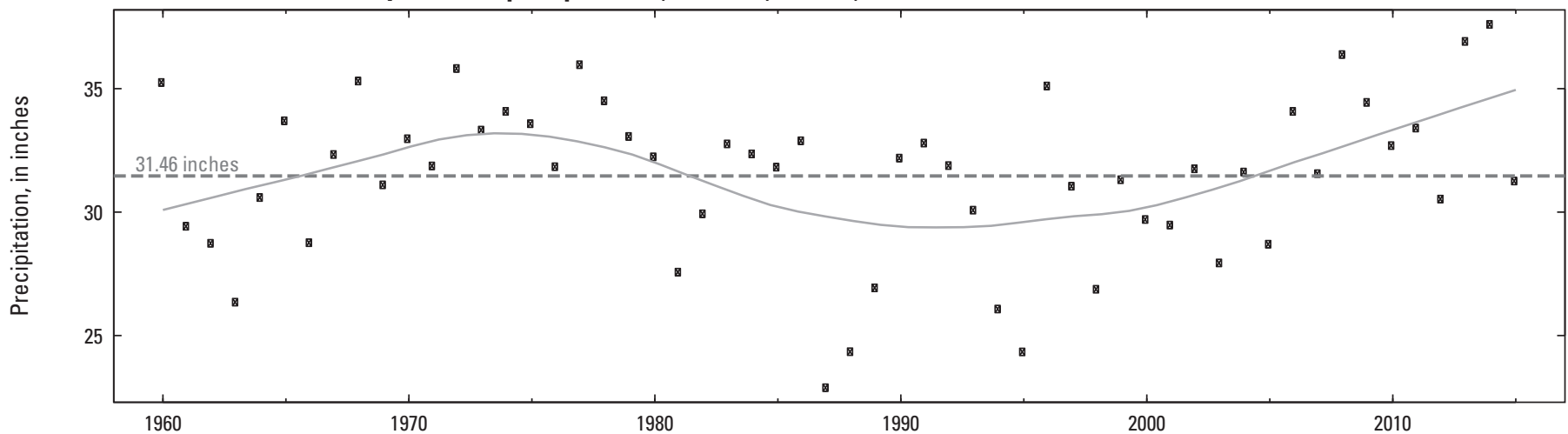

C. Annual total of monthly runoff [probability value $(p$-value $)=0.5527$, Kendall's tau $(\tau)=0.0545$ ]

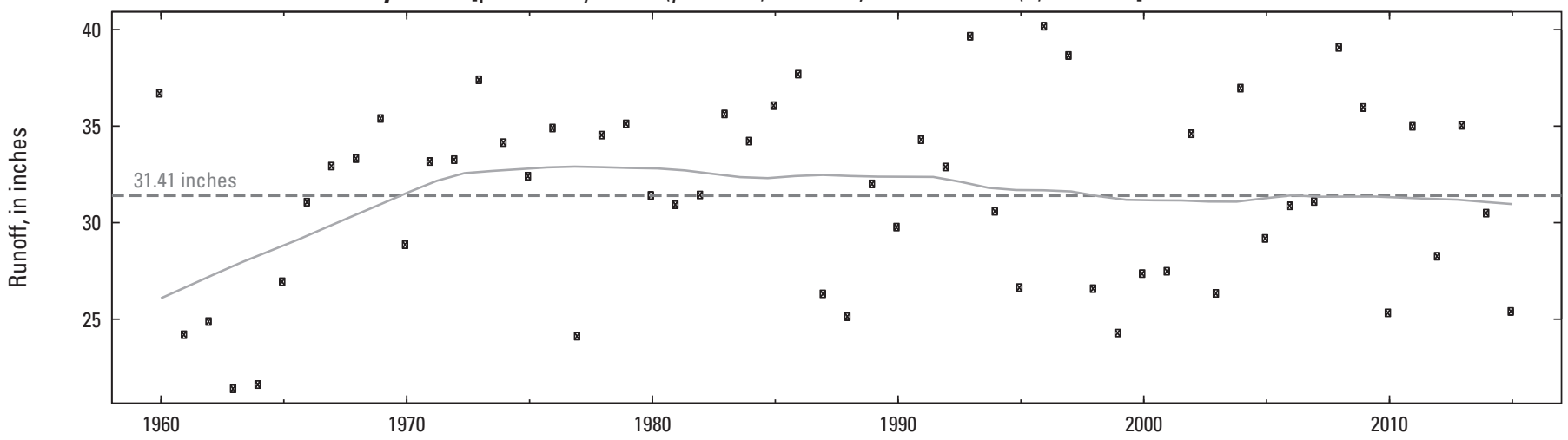

D. Annual total of monthly overlake evaporation [probability value $(p$-value $)=0.0150$, Kendall's tau $(\tau)=0.2234$ ]

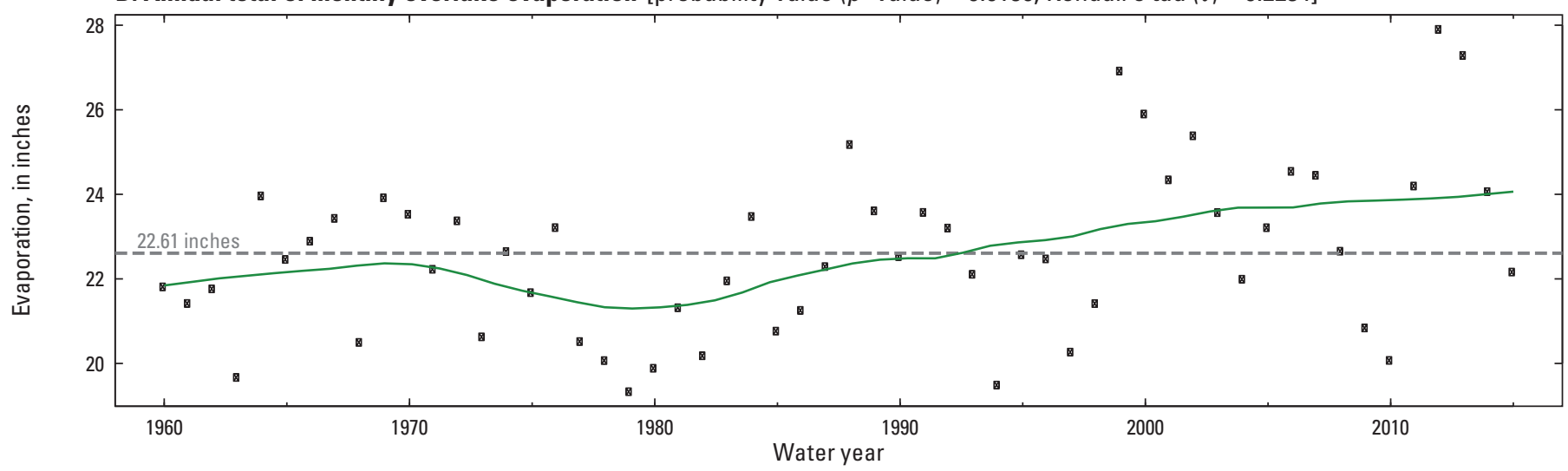

Figure 21. Trends in major water-budget components for the Great Lakes Basin, water years 1960-2015. $A$, annual mean of lake outflow; $B$, annual total of monthly overlake precipitation; $C$, annual total of monthly runoff; and $D$, annual total of monthly overlake evaporation. 
Table 2. Mean relative contributions to the Great Lakes Basin outflow and major water-budget components, by lake, water years 1960-2015.

$\left[\mathrm{ft}^{3} / \mathrm{s}\right.$, cubic foot per second; NA, not applicable]

\begin{tabular}{|c|c|c|c|c|c|c|c|c|c|c|c|}
\hline \multirow{2}{*}{ Lake } & \multicolumn{4}{|c|}{$\begin{array}{l}\text { Lake surface and drainage basin areas } \\
\text { (square miles) and percent of total } \\
\text { combined areas }\end{array}$} & \multicolumn{3}{|c|}{$\begin{array}{l}\text { Lake outflow }\left(\mathrm{ft}^{3} / \mathrm{s}\right) \text {, } \\
\text { contribution by lake }\left(\mathrm{ft}^{3} / \mathrm{s}\right) \text {, } \\
\text { and percent of total for entire } \\
\text { basin }\end{array}$} & \multicolumn{4}{|c|}{$\begin{array}{l}\text { Major water-budget components, in inches } \\
\text { (relative to lake surface area) }\end{array}$} \\
\hline & $\begin{array}{l}\text { Lake } \\
\text { surface }\end{array}$ & $\begin{array}{l}\text { Drainage } \\
\text { basin }\end{array}$ & $\begin{array}{l}\text { Combined } \\
\text { lake and } \\
\text { land }\end{array}$ & $\begin{array}{l}\text { Percent } \\
\text { of } \\
\text { total }\end{array}$ & $\begin{array}{l}\text { Lake } \\
\text { outflow }\end{array}$ & $\begin{array}{l}\text { Individual } \\
\text { lake }\end{array}$ & $\begin{array}{l}\text { Percent } \\
\text { of } \\
\text { total }\end{array}$ & $\begin{array}{c}\text { Overlake } \\
\text { precipitation }\end{array}$ & $\begin{array}{l}\text { Runoff } \\
\text { from } \\
\text { drainage } \\
\text { basin }\end{array}$ & $\begin{array}{c}\text { Overlake } \\
\text { evaporation }\end{array}$ & $\begin{array}{c}\text { Net } \\
\text { basin } \\
\text { supply }\end{array}$ \\
\hline Superior & 31,700 & 49,400 & 81,100 & 27.4 & 76,100 & 76,100 & 29.5 & 29.2 & 23.4 & 22.1 & 30.5 \\
\hline $\begin{array}{l}\text { Michigan and Huron, } \\
\text { combined }\end{array}$ & 45,300 & 97,400 & 142,700 & 48.2 & 188,100 & 112,000 & 43.4 & 31.9 & 29.0 & 19.8 & 41.1 \\
\hline Saint Clair & 430 & 6,100 & 6,530 & 2.2 & 194,500 & 6,400 & 2.5 & 32.0 & 179.0 & 39.9 & 171.1 \\
\hline Erie & 9,900 & 23,600 & 33,500 & 11.3 & 221,400 & 26,900 & 10.4 & 34.7 & 33.2 & 34.2 & 33.7 \\
\hline Ontario & 7,300 & 24,700 & 32,000 & 11.3 & 257,900 & 36,500 & 14.2 & 34.1 & 69.9 & 25.7 & 78.3 \\
\hline Entire basin & 94,630 & 201,200 & 295,830 & 100 & 257,900 & NA & 100 & 31.5 & 31.4 & 22.6 & 40.3 \\
\hline
\end{tabular}

${ }^{a}$ Net basin supply is the sum of overlake precipitation and runoff from drainage basin, less overlake evaporation. Any minor differences from data in figure 22 are from rounding.

Examination of monthly means for overlake precipitation, runoff, overlake evaporation, and NBS for the Great Lakes and the Great Lakes Basin (figs. 28-33) provides insights into the dynamics driving the lake-level fluctuations. On average, NBS for Lake Superior is small during November-February (fig. 28), and even negative during December and January, which results from large evaporation, relative to the sum of precipitation and runoff. Cumulative evaporation from all the Great Lakes is largest during fall and winter (fig. 33), which is typical for all the individual lakes except Lake Saint Clair (fig. 30), which is shallow (fig. 15) and is affected by different thermodynamic processes. On average, NBS for Lake Superior increases substantially during March, which, in combination with dynamics of lake outflow, results in March as the most typical month for minimum lake level (fig. 23). On average, monthly overlake evaporation from Lake Superior during April-August is less than $1 \mathrm{in}$., which results in large NBS and accumulating in-lake storage. During June and July, mean evaporation is slightly negative for Lake Superior (fig. 28), which results from condensation of atmospheric moisture on the lake's surface and is common during months of minimal evaporation. The maximum annual lake level in Lake Superior most typically is during September or October (fig. 23), when accumulation of in-lake storage ceases because of the combination of decreasing NBS (fig. 28) and maximum lake outflow associated with the annual maximum lake level.

Patterns in mean monthly water-budget components for Lakes Michigan and Huron (fig. 29) are similar in many respects to those of Lake Superior (fig. 28) and have primary differences of larger mean NBS for November-April, including positive NBS for December and January. These differences, in combination with the added dimension of outflow from Lake Superior as an inflow component, are the primary drivers for the substantial differences in timing of annual minimum and maximum lake levels for Lakes Michigan and Huron (fig. 24), relative to Lake Superior (fig. 23).

Patterns in mean monthly water-budget components for the Great Lakes Basin (fig. 33) are largely similar to patterns for Lake Superior (fig. 28) and Lakes Michigan and Huron (fig. 29) because of the large contribution of about 73 percent to the overall water budget from these large lakes and associated drainage areas (table 2). However, patterns in monthly mean water-budget components for the three downstream Great Lakes (Saint Clair, Erie, and Ontario; figs. 30-32) are substantially different from the upstream Great Lakes, with a general exception of overlake precipitation, for which striking differences are not apparent. Runoff is proportionally larger for the downstream lakes because drainage areas are proportionally larger, relative to lake surface areas, than for the upstream lakes (table 1). Evaporation patterns for Lake Ontario are largely similar to patterns for Lake Superior and Lakes Michigan and Huron; however, substantial differences are apparent for Lake Saint Clair and Lake Erie, which likely are associated with shallower depths for these lakes. The NBS patterns for the three downstream lakes reflect the major effects of the increased effect of runoff for many months, with effects from evaporation patterns most notable for Lake Erie, where NBS is strongly negative during September and October. 
A. Lake Superior net basin supply [probability value $(p$-value $)=0.0202$, Kendall's tau $(\tau)=-0.2162$ ]

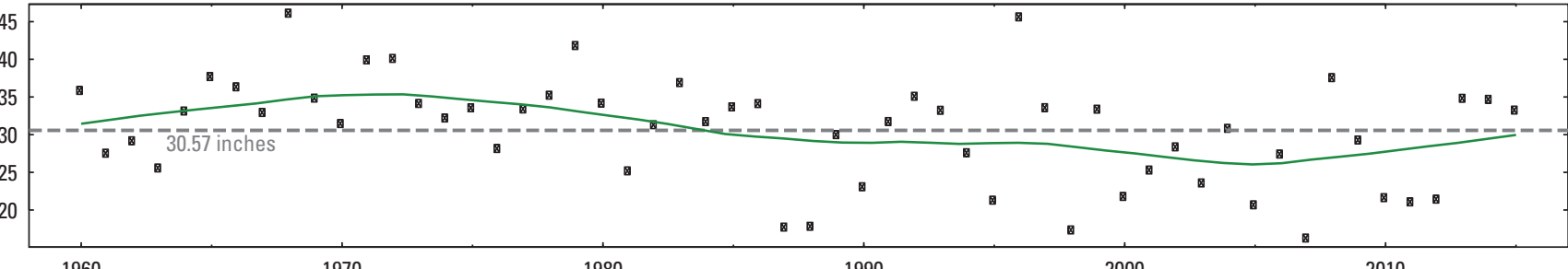

B. Lakes Michigan and Huron net basin supply [probability value $(p$-value $)=0.5614$, Kendall's tau $(\tau)=0.0545$ ]

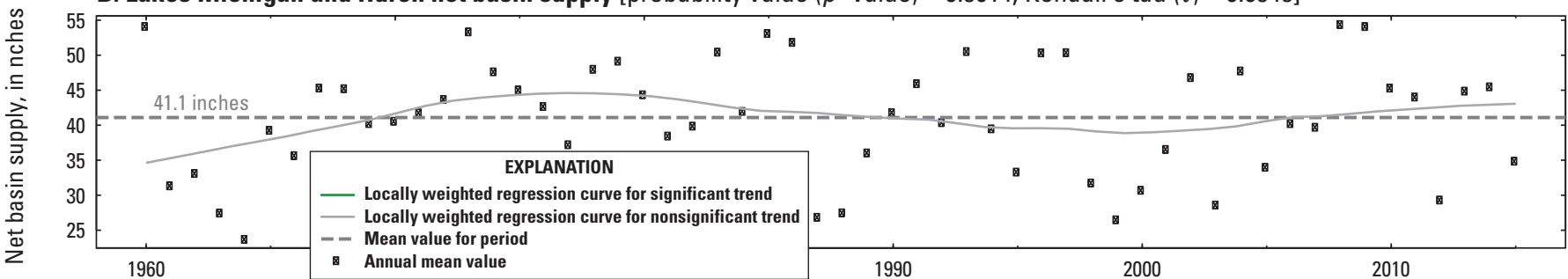

C. Lake Saint Clair net basin supply [probability value $(p$-value $)=0.0467$, Kendall's tau $(\tau)=0.1852$ ]

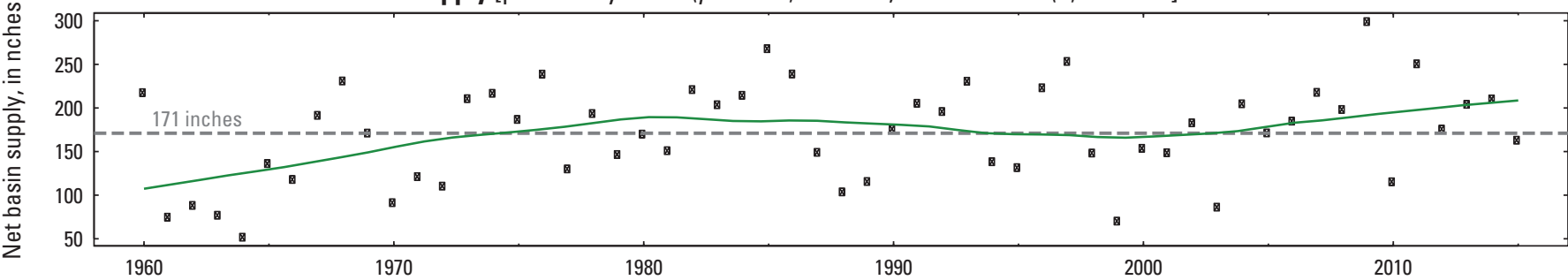

D. Lake Erie net basin supply [probability value $(p$-value $)=0.4246$, Kendall's tau $(\tau)=0.0747$ ]

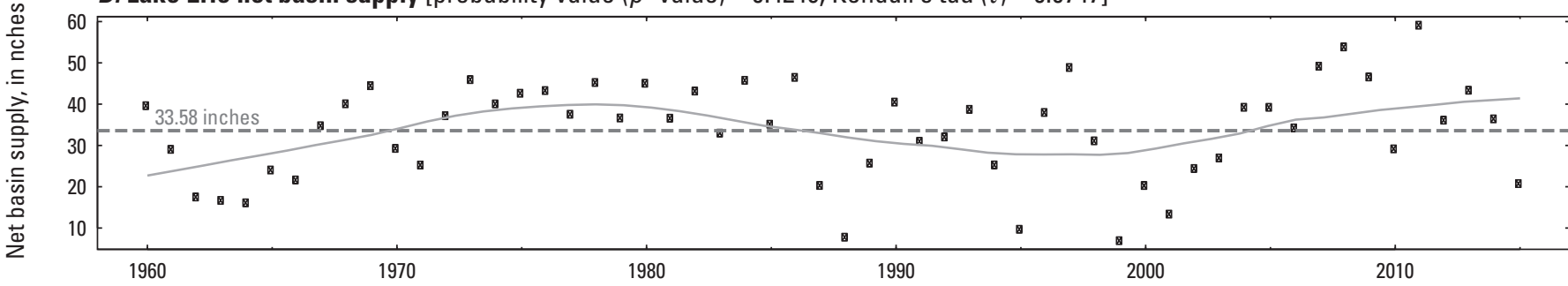

E. Lake Ontario net basin supply [probability value $(p$-value $)=0.0572$, Kendall's tau $(\tau)=0.1771$ ]

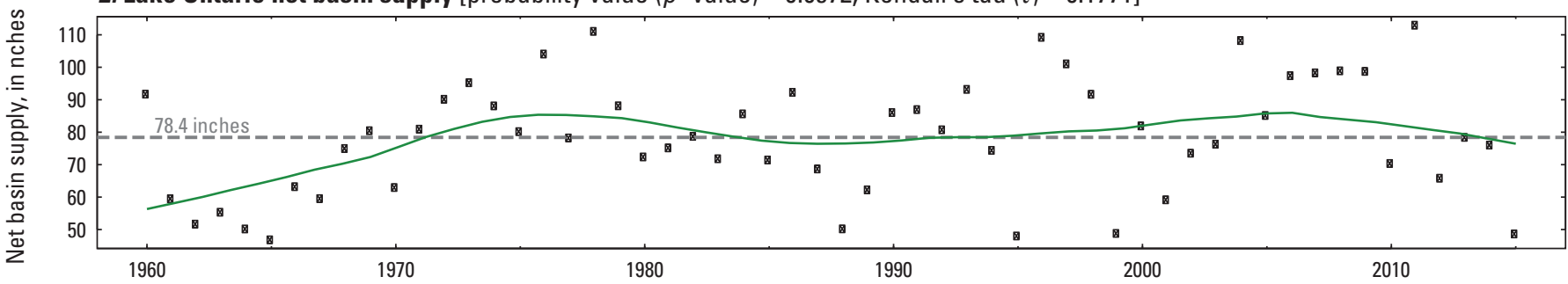

F. Great Lakes Basin net basin supply [probability value $(p$-value $)=0.8050$, Kendall's tau $(\tau)=0.0236$ ]

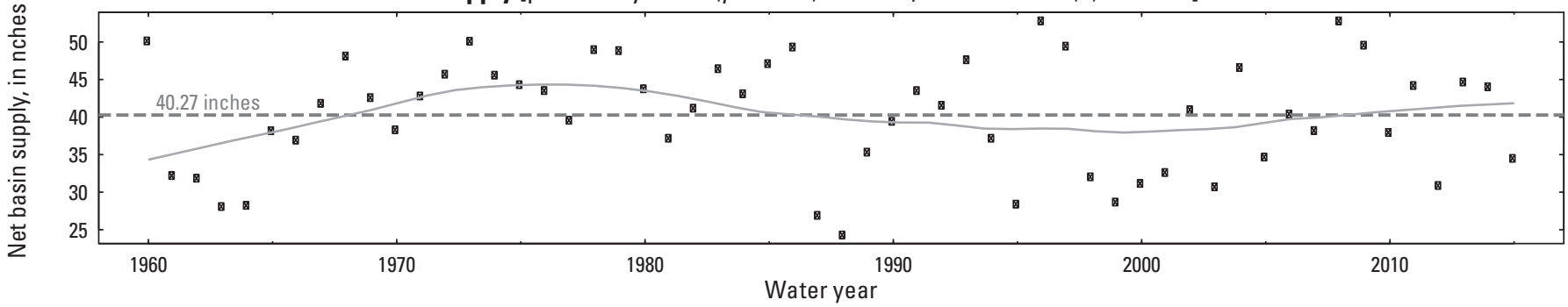

Figure 22. Trends in annual net basin supply for the individual Great Lakes and for the Great Lakes Basin, water years 1960-2015. $A$, Lake Superior; B, Lakes Michigan and Huron; $C$, Lake Saint Clair; D, Lake Erie; E, Lake Ontario; and F, Great Lakes Basin. 


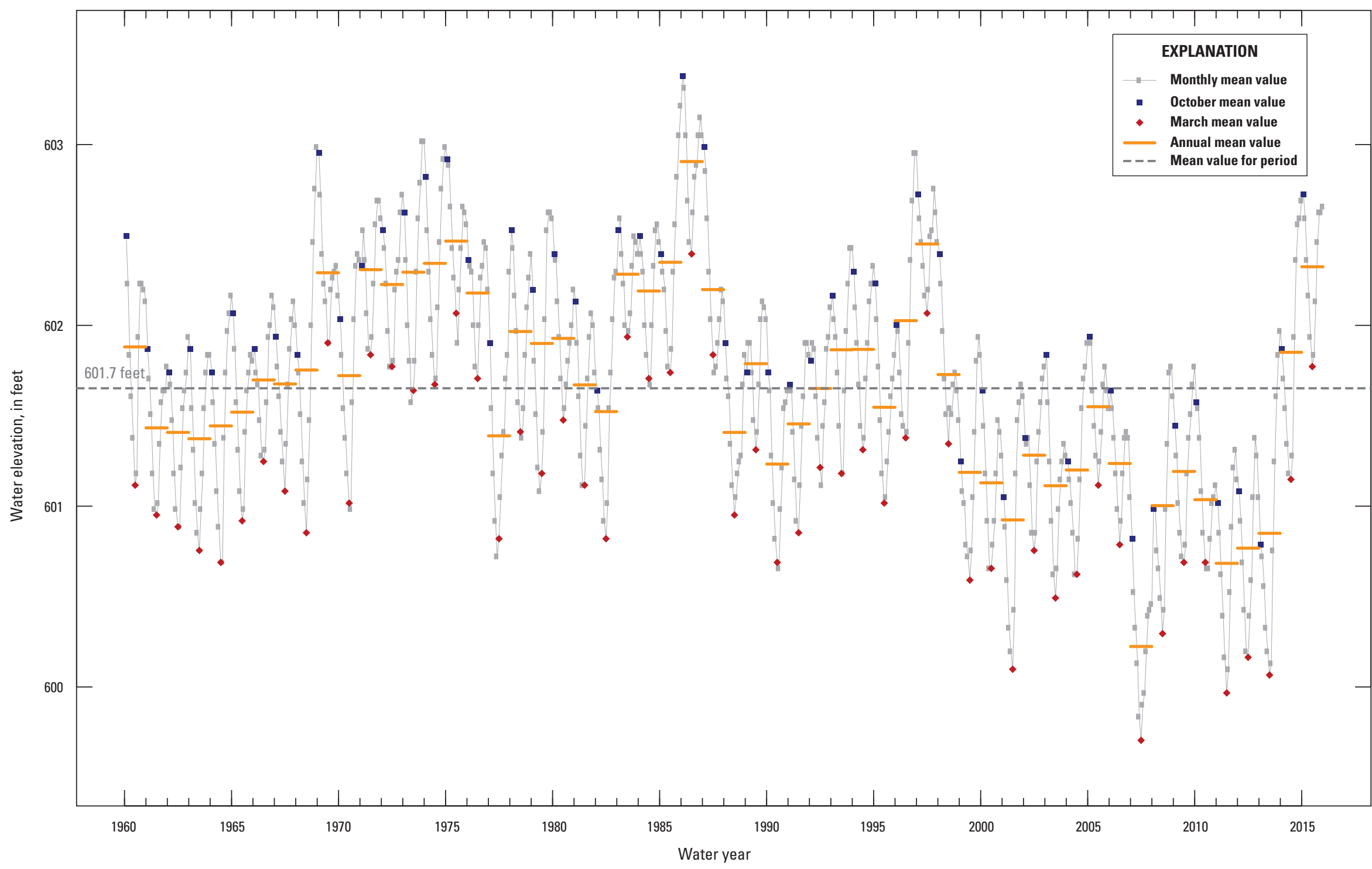

Figure 23. Monthly mean lake levels for Lake Superior, water years 1960-2015. 


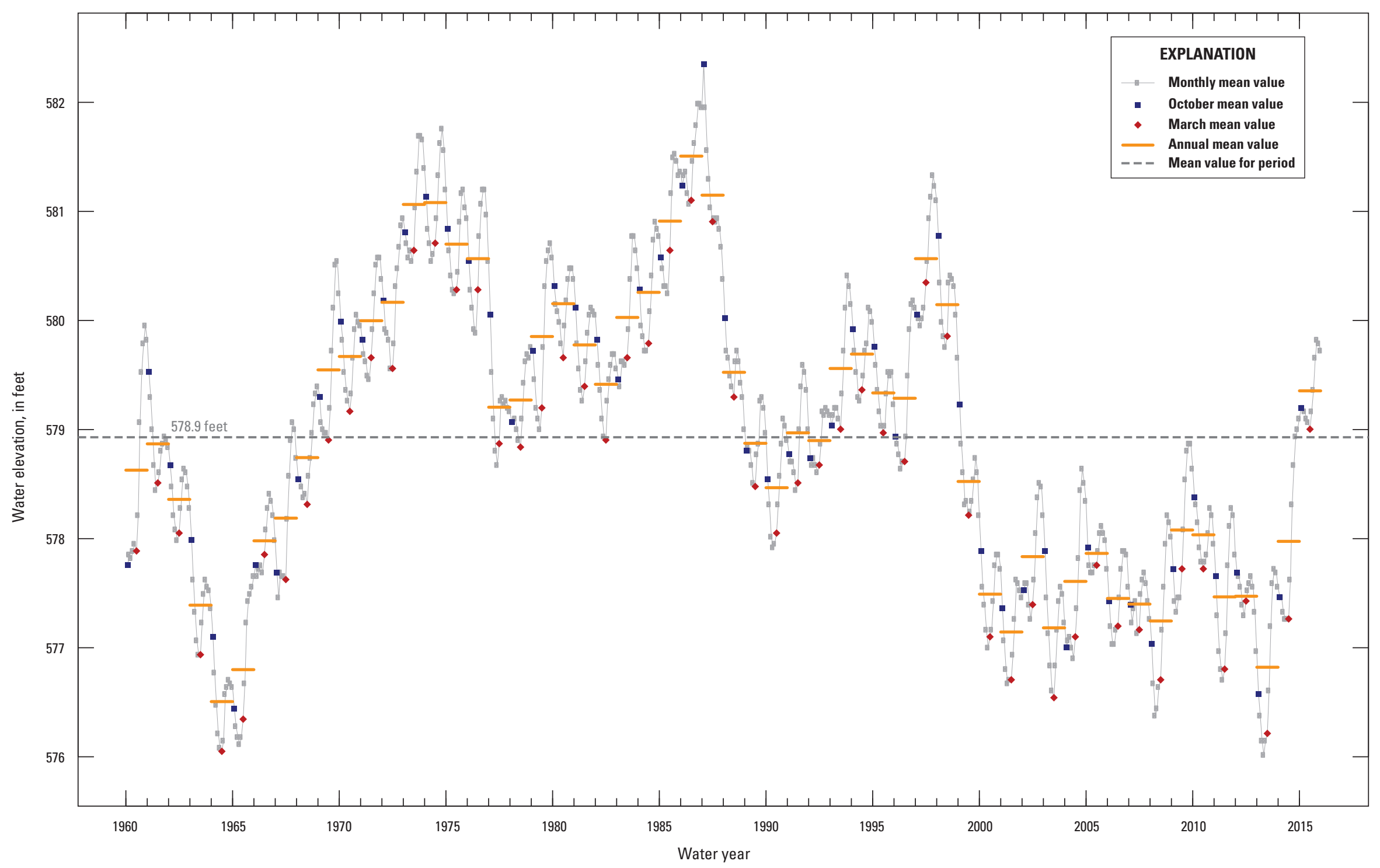

Figure 24. Monthly mean lake levels for Lakes Michigan and Huron, water years 1960-2015. 


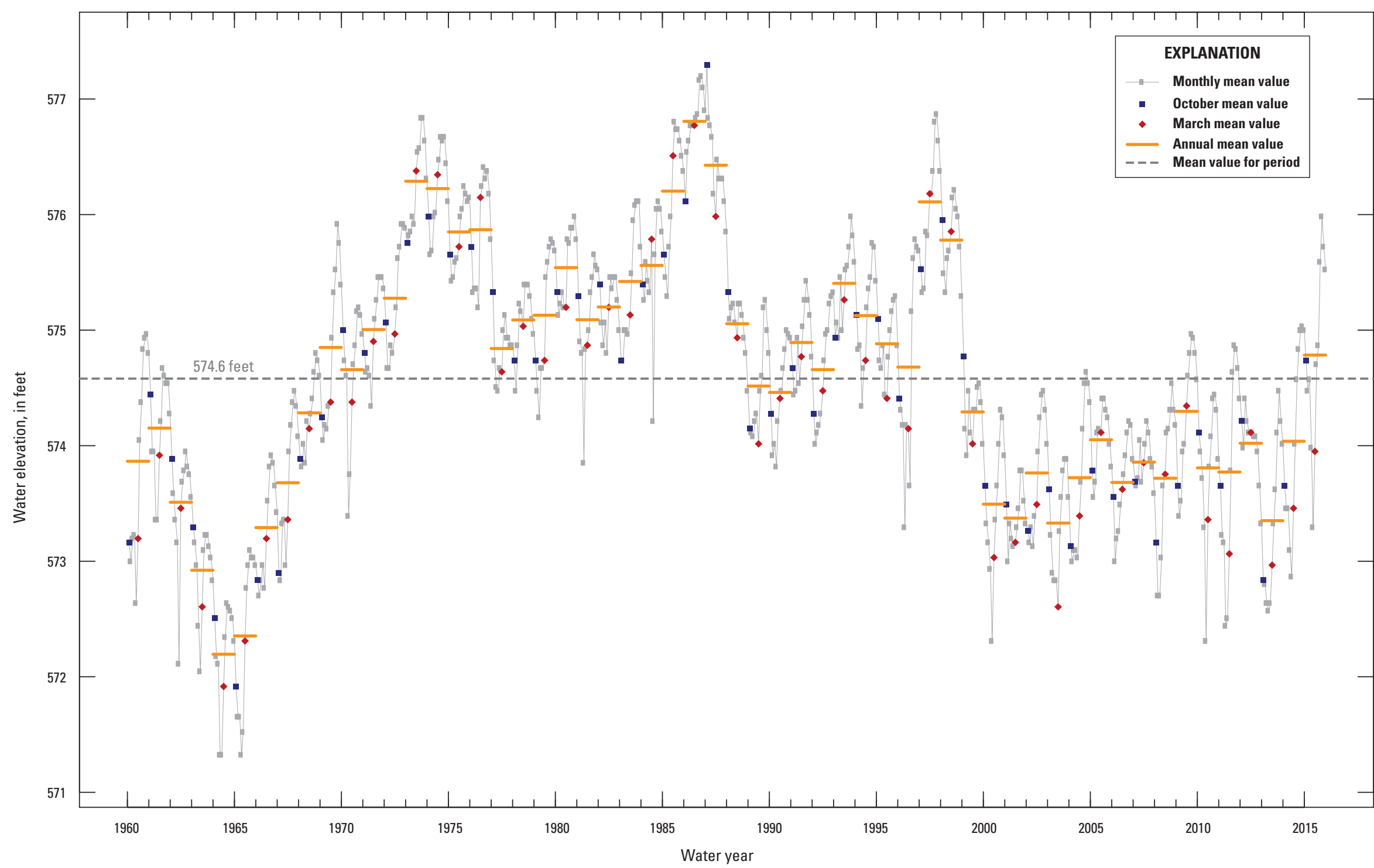

Figure 25. Monthly mean lake levels for Lake Saint Clair, water years 1960-2015. 


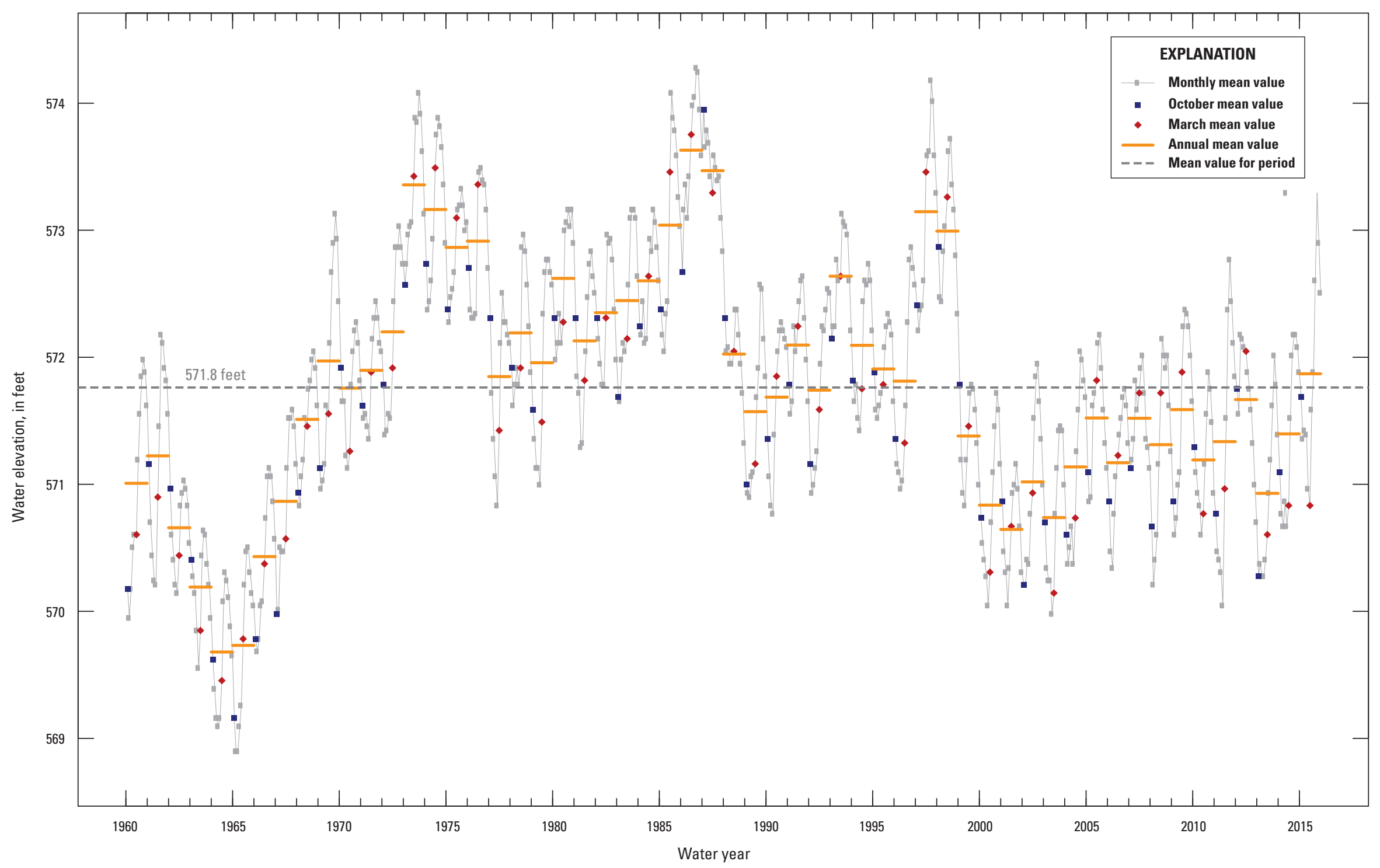

Figure 26. Monthly mean lake levels for Lake Erie, water years 1960-2015. 


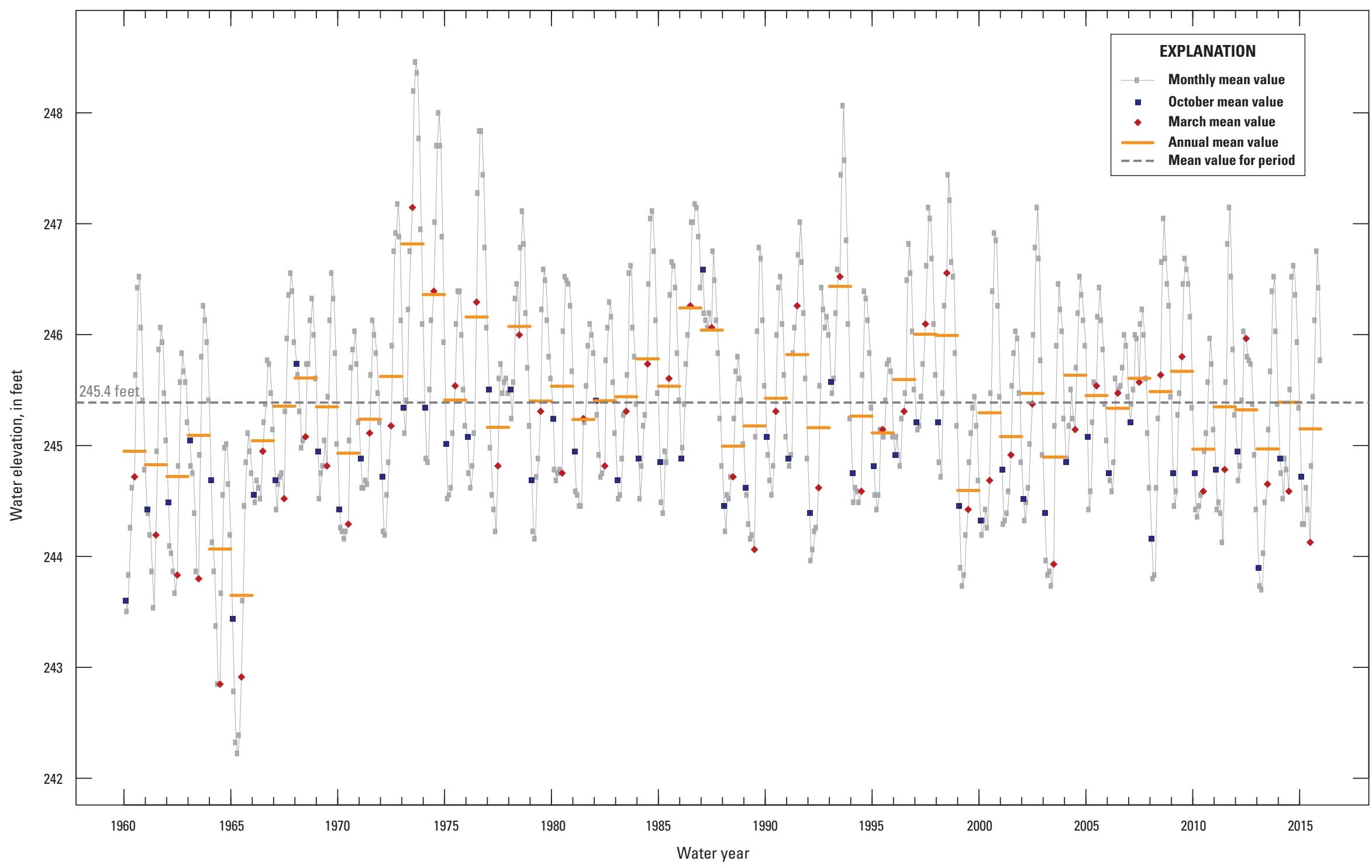

Figure 27. Monthly mean lake levels for Lake Ontario, water years 1960-2015. 


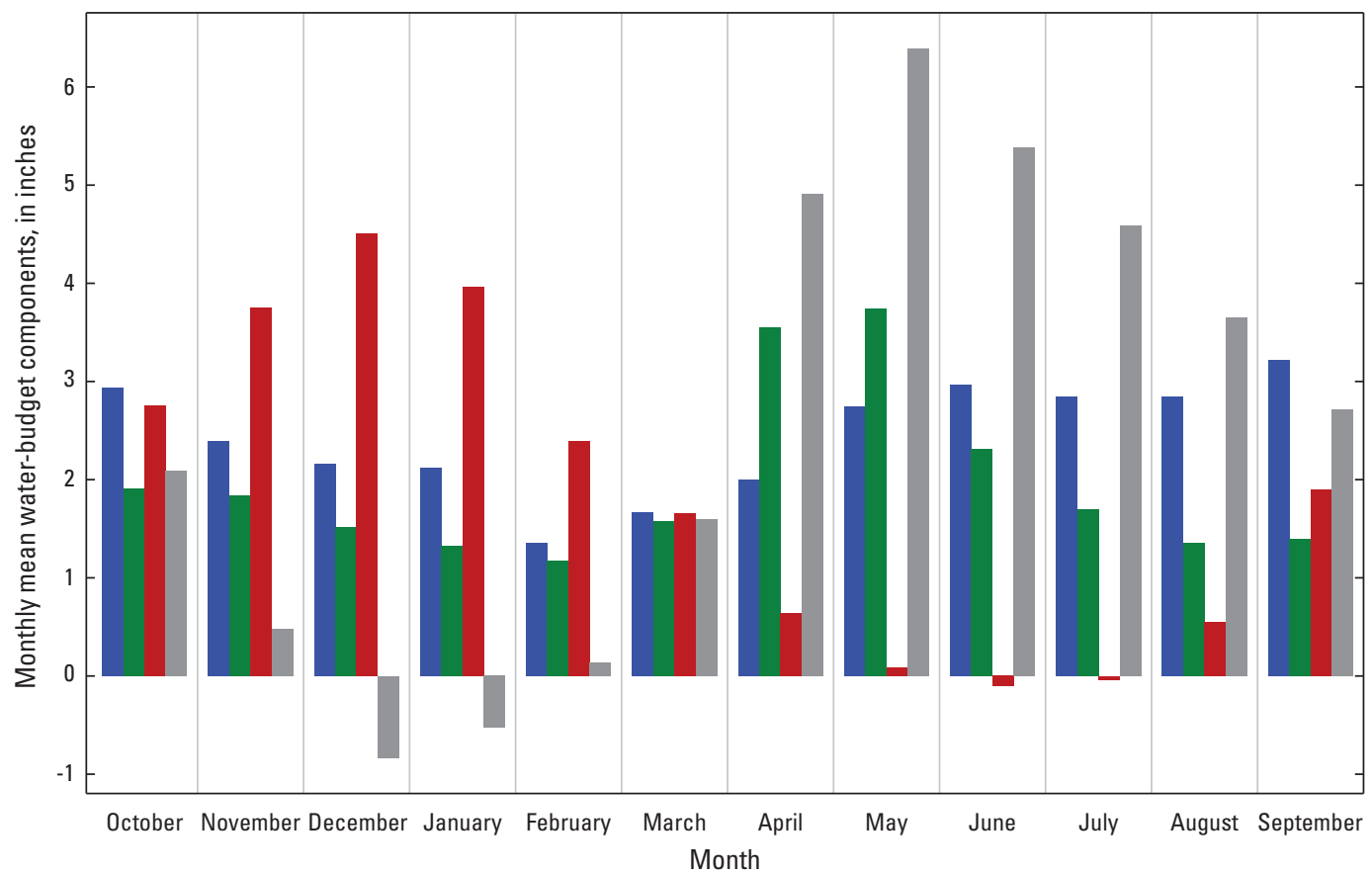

EXPLANATION

- Precipitation

- Runoff

Evaporation

- Net basin supply

Figure 28. Means of monthly overlake precipitation, runoff, overlake evaporation, and net basin supply for Lake Superior, water years 1960-2015.

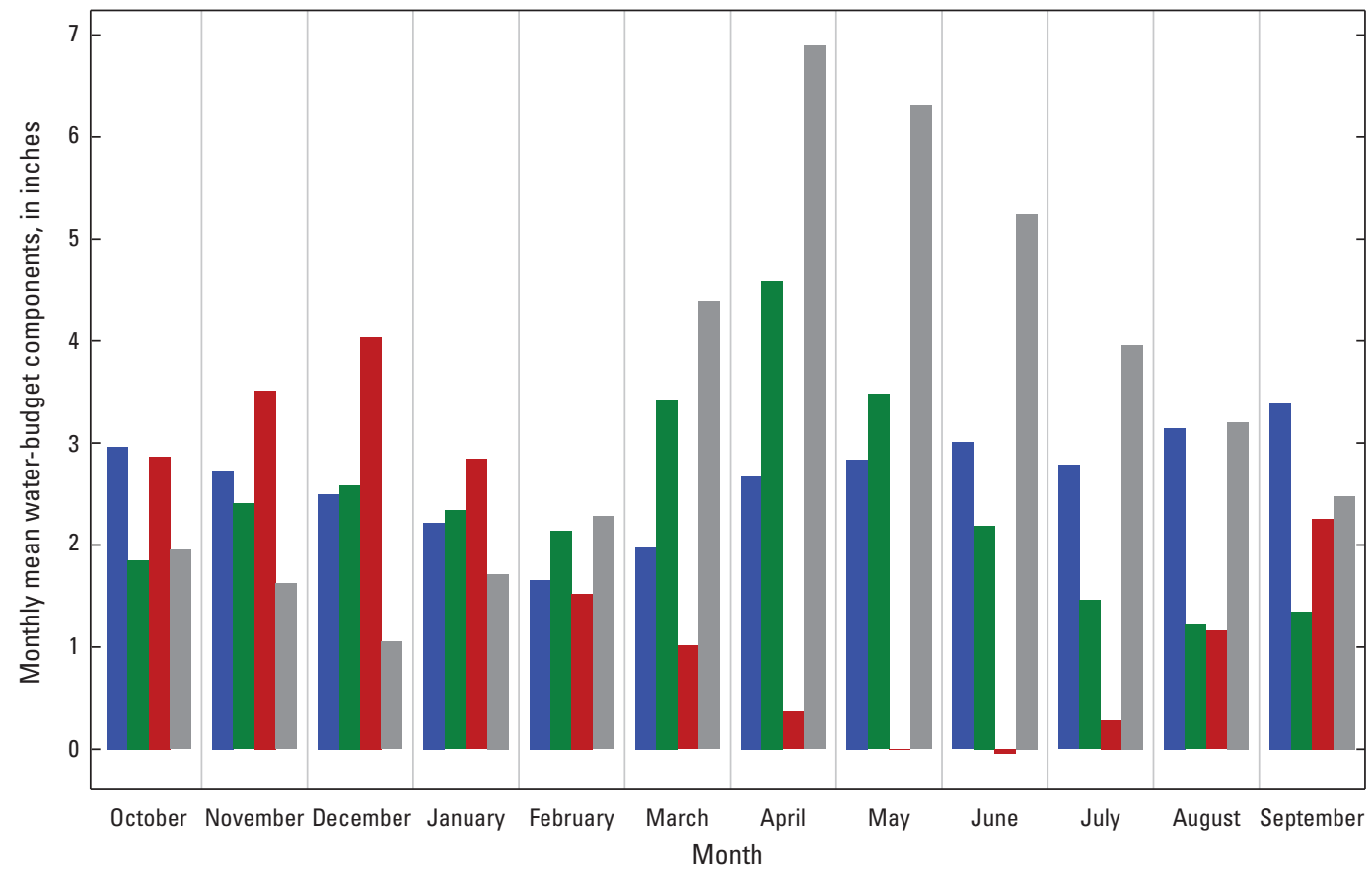

EXPLANATION

- Precipitation

- Runoff

- Evaporation

- Net basin supply

Figure 29. Means of monthly overlake precipitation, runoff, overlake evaporation, and net basin supply for Lakes Michigan and Huron, water years 1960-2015. 


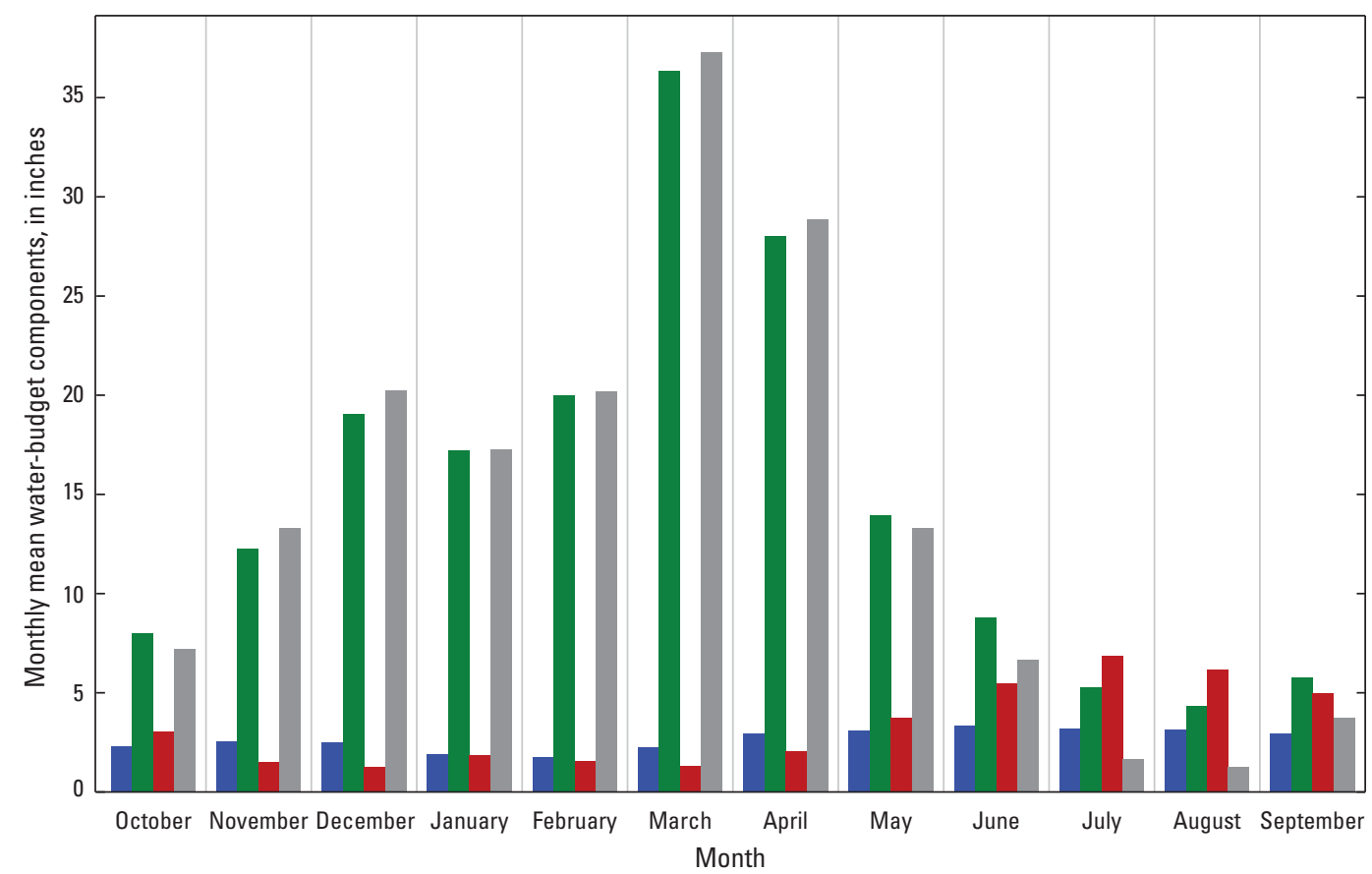

EXPLANATION

- Precipitation

- Runoff

- Evaporation

- Net basin supply

Figure 30. Means of monthly overlake precipitation, runoff, overlake evaporation, and net basin supply for Lake Saint Clair, water years 1960-2015.

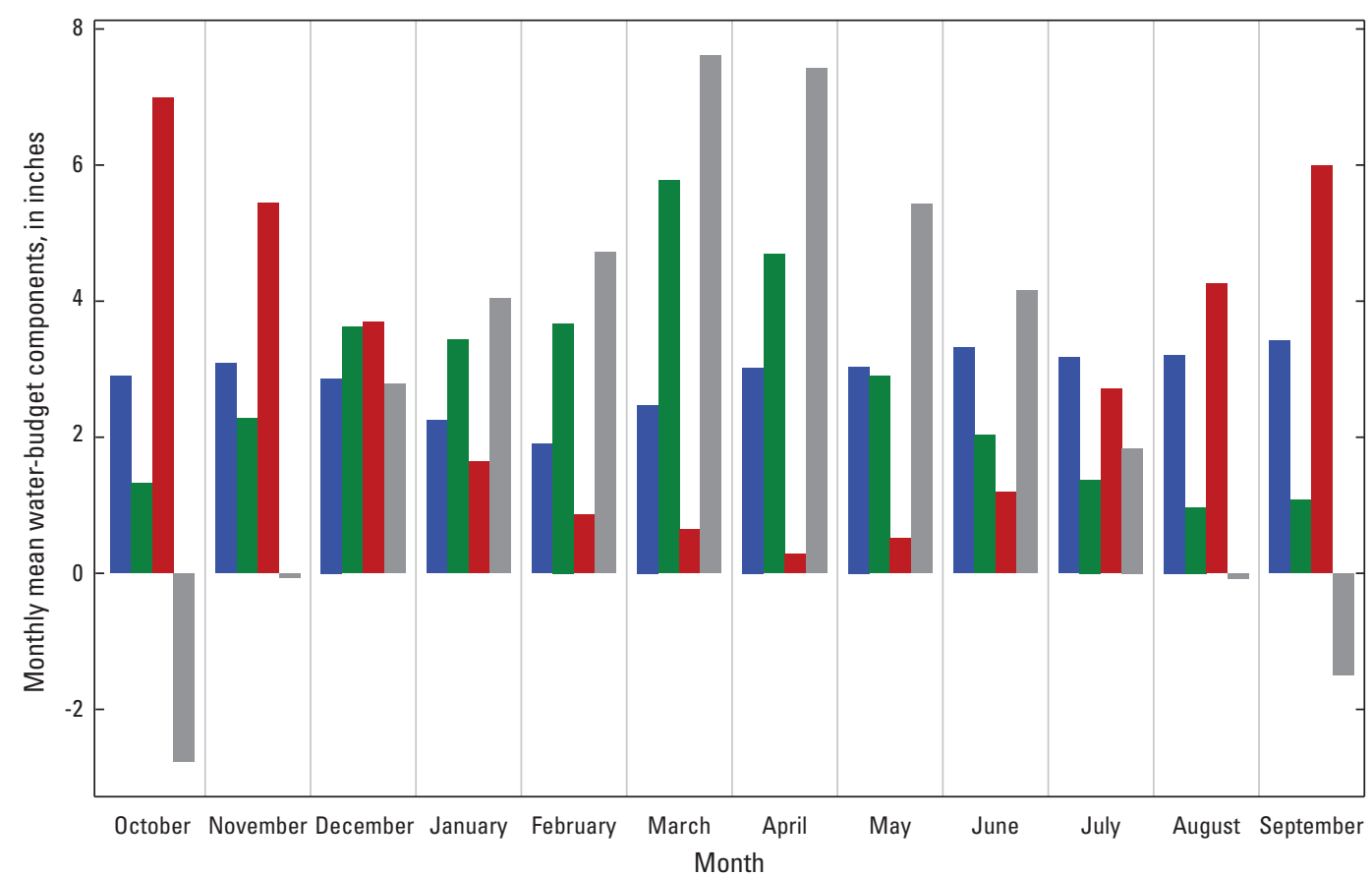

EXPLANATION

- Precipitation

Runoff

- Evaporation

Net basin supply

Figure 31. Means of monthly overlake precipitation, runoff, overlake evaporation, and net basin supply for Lake Erie, water years 19602015. 


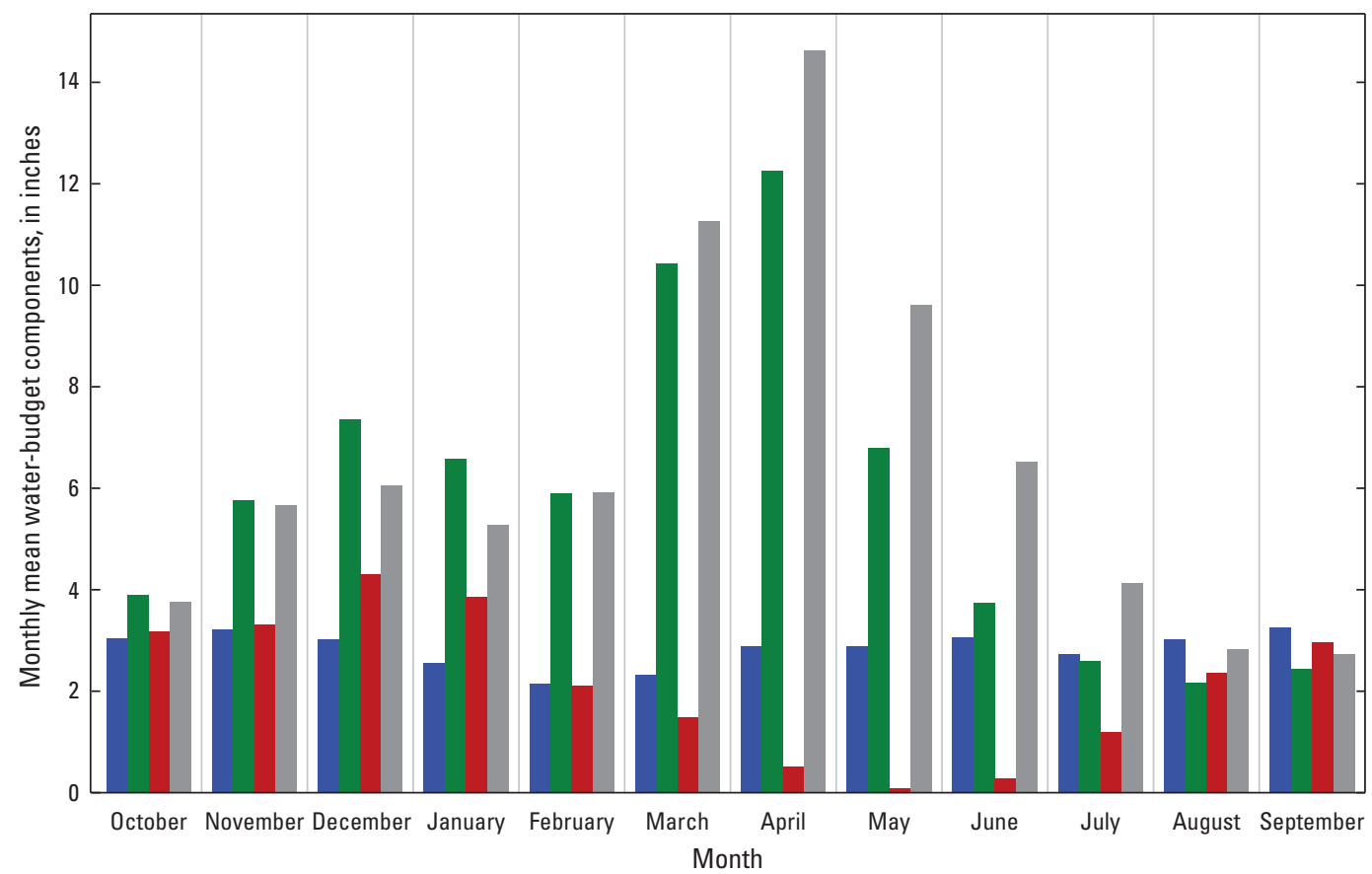

EXPLANATION

- Precipitation

- Runoff

- Evaporation

- Net basin supply

Figure 32. Means of monthly overlake precipitation, runoff, overlake evaporation, and net basin supply for Lake Ontario, water years 1960-2015.

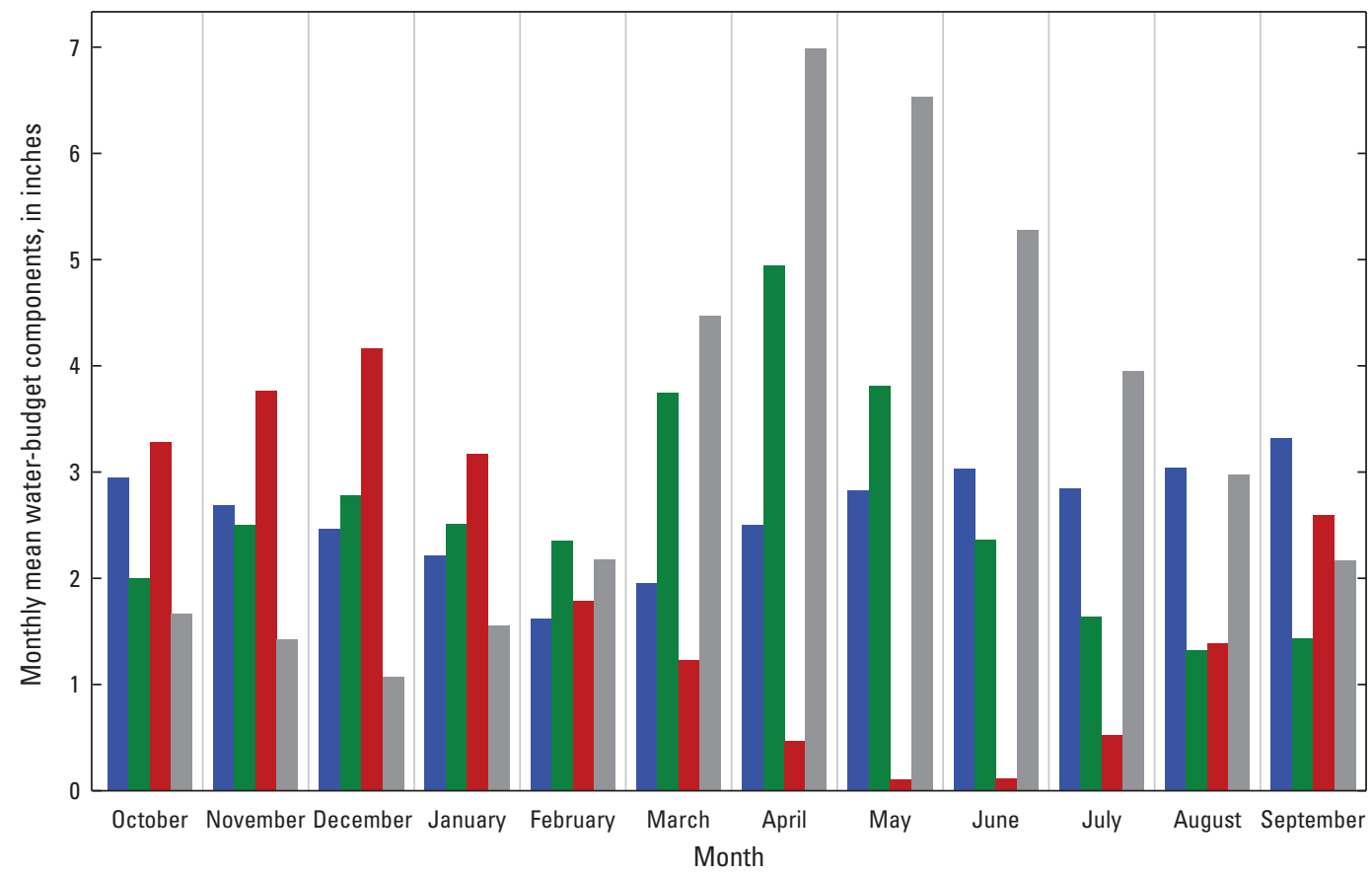

EXPLANATION

Precipitation

- Runoff

Evaporation

Net basin supply

Figure 33. Means of monthly overlake precipitation, runoff, overlake evaporation, and net basin supply for the Great Lakes Basin, water years 1960-2015. 
Despite the substantial differences in water-budget components for Lake Saint Clair and Lake Erie (figs. 30 and 31 ), their sawtooth patterns in monthly lake levels (figs. 25 and 26) closely mimic those for Lakes Michigan and Huron (fig. 24), especially relative to the major extended periods of above- or below-mean conditions. Contributions from the Lake Saint Clair and Lake Erie Basins to the total outflow from the Great Lakes Basin are only 2.5 and 10.4 percent, respectively, relative to the combined contribution of 72.9 percent from the upstream lakes (table 2). Thus, it can be inferred that outflow from Lakes Michigan and Huron is highly influential as a driving factor for multiyear patterns in lake levels for Lake Saint Clair and Lake Erie. The remaining contribution of 14.2 percent from the Lake Ontario Basin (table 2) also is relatively small; however, the multiyear patterns in lake levels (fig. 27) differ substantially from the upstream lakes, which likely is primarily because of effects of regulation.

Timing of annual minima and maxima lake levels for Lakes Michigan and Huron (fig. 24) is much different from Lake Saint Clair and Lake Erie (figs. 25 and 26), where annual minima almost never occurred in March and annual maxima almost never occurred in October. For Lake Saint Clair, it is noteworthy that magnitudes of monthly lake-level changes associated with annual minima can be larger than for any of the other Great Lakes (figs. 23-27), and monthly changes of $1 \mathrm{ft}$ or more are relatively common. A good example is WY 1984, when the annual minimum occurred in April and the monthly mean was smaller than those for March and May by more than $1.5 \mathrm{ft}$. Especially large monthly increases in lake level likely can be attributed primarily to large runoff, which on average exceeds $1 \mathrm{ft}$ (relative to the surface area of Lake Saint Clair) for November-May, $2 \mathrm{ft}$ for April, and $3 \mathrm{ft}$ for March (fig. 30). Especially large monthly decreases cannot be attributed primarily to evaporation, which is too small to be a primary driver (fig. 30). A more typical driver likely is the combination of large lake outflows during months of small precipitation and runoff. Neff and Nicholas (2005) described hydraulic effects associated with ice jamming, wind setup, and seiche that can cause substantial retardation of outflow from Lakes Michigan and Huron. The subsequent release of stored water to Lake Saint Clair may be another driving factor for large rises in lake level.

\section{Additional Perspectives on Lake-Level Trends for Water Years 1960-2015}

Although trends in climatic data (from PRISM) could be considered only for the U.S. part of the Great Lakes Basin, and ECCC streamgages for analysis of streamflow trends are sparse, the climate and streamflow trends are consistent with trends in lake levels and associated major water-budget components, which are derived from other data sources. The spatial distribution of trends in climatic data for 1960-2015 for the U.S. part of the Great Lakes Basin (fig. 9) clearly indicates (1) nearly ubiquitous upward trends in $T_{\min }$ and (2) a sharp transition from neutral or downward trends in precipitation northwest of Lake Michigan to generally upward trends east of Lake Michigan. The downward precipitation trends northwest of Lake Michigan combined with the upward trends in $T_{\min }$ drive downward trends in runoff into Lake Superior. The climatic trends northwest of Lake Michigan presumably extend throughout the Canadian part of the Lake Superior Basin, as indicated by the statistically significant downward trend in runoff (fig. 16D) and upward trend in evaporation (fig. 16E) for Lake Superior. In combination, the precipitation, runoff, and evaporation trends drive statistically significant downward trends in NBS (fig. 22A) and lake outflow (fig. 16B) for Lake Superior.

The NBS trend for 1960-2015 is neutral for Lakes Michigan and Huron combined (fig. 22B), despite the significant upward trend for evaporation (fig. 17E) that is offset by neutral trends for precipitation and runoff and reflects the spatial transition between downward and upward trends in precipitation near Lake Michigan (fig. 9). Thus, it can be surmised that the statistically significant downward trend in lake outflow for Lakes Michigan and Huron combined (fig. 17B) is driven to at least some extent by the downward trend in outflow from Lake Superior (fig. 16B). Trends in NBS are neutral to mildly upward for the remainder of the downstream lakes (figs. $22 C, D$, and $E$ ) and collectively combine to offset the effect of the downward trend in outflow from Lakes Michigan and Huron (fig. 17B) and result in neutral outflow trends for the downstream lakes (figs. 18B, $19 B$, and 20B).

The statistically significant upward trend in evaporation for the Great Lakes Basin (fig. 21D) and associated upward trends for the individual lakes (Lake Saint Clair excepted, graph $E$ of figs. 16-20) is an important factor for Great Lakes water-budget considerations. This is a topic that has been extensively addressed by other researchers (for example, Lenters and others, 2013; Hunter and others, 2015). Decreased ice cover is considered an important factor in driving increased evaporation; however, various other complex thermodynamic factors also are involved (Lenters and others, 2013).

Although evaporation is clearly an important factor for Great Lakes water budgets and trends, the importance of precipitation and runoff is not to be dismissed. Without the offsetting effect of the upward trends for these variables for some of the downstream lakes, the prolonged trend of low NBS and low outflow for Lake Superior during 1998-2014 would have had considerably more effect for the downstream lakes. The importance of precipitation and runoff is additionally illustrated by the low lake levels in the downstream lakes during the 1960s (graph $A$ of figs. 17-20), when consecutive years of low NBS existed (fig. 22A-E), despite evaporation in the downstream lakes that generally was smaller than during 1998-2014 (graph $E$ of figs. 17-20). 


\section{Implications Regarding Serial Correlation in Trend Analyses}

An emerging and growing area of study is potential effects of serial correlation on trend analyses. For this study, the Mann-Kendall test was used to assess the statistical significance of trends. Although the Mann-Kendall test is appropriate for time series that are independent, identically distributed, and have no short- or long-term persistence (Wilks, 2011), violations of these assumptions (for example, when series are autocorrelated) can cause an inflation of $p$-values resulting in increased type I errors (that is, accepting a trend as significant when, in fact, no trend exists). Longterm persistence is difficult to prove with periods of record less than 50-100 years (Hodgkins and Dudley, 2011) and was not considered a major concern for this study, which includes 56 years of record; however, short-term persistence (STP) is of potential concern. Although the scope of this study did not allow examining time-series data for the presence and effect of STP before trend analysis, it is beneficial to briefly explore how the presence of STP might affect the outcome of trend analyses. Time-series data used in this study were examined for the presence of STP using the Ljung-Box test (Ljung and Box, 1978) from the R stats package (R Core Team, 2017). STP was considered statistically significant for $p$-values less than or equal to 0.10 for lags as much as 3 in the time series. A modified Mann-Kendall test was then used to complete trend analyses for time-series data with statistically significant STP. Various methods can be used to modify the Mann-Kendall test to minimize the effect of STP and (or) long-term persistence (Bayazit, 2015; Hamed, 2008; Önöz and Bayazit, 2012). A modified Mann-Kendall test from the zyp R package developed by Bronaugh and Werner (2013) was used for trend analysis of those time series that have statistically significant STP. The zyp.trend.vector function with the "Zhang" method was used; this method applies the Mann-Kendall test to a prewhitened nonlinear trend using the Zhang method as described by Wang and Swail (2001).

Results from the Ljung-Box test (Ljung and Box, 1978) and modified Mann-Kendall test are included in tables 1.3 through 1.5. Results for climate data obtained using PRISM are presented in table 1.3. Results for streamflow data are presented in table 1.4. Results for water-budget components are presented in table 1.5. Comparisons of results from standard and modified Mann-Kendall tests are described within the remainder of this section.

The time-series data for the area-weighted means for precipitation, $T_{\min }$, and $T_{\max }$ from PRISM (figs. 3-8) generally indicated no statistically significant STP (table 1.3), with exceptions for drainage basins for Lake Erie (significant STP in precipitation) and Lake Ontario (significant STP in precipitation and $T_{\min }$ ). However, for precipitation, $T_{\min }$, and $T_{\max }$, statistically significant upward trends were indicated by the standard and modified Mann-Kendall tests; thus, overall effects of serial correlation on trend analyses for climate data from PRISM are considered inconsequential.

Significant STP in annual streamflow was documented for 73 out of 103 USGS streamgages and 6 out of 35 ECCC streamgages (table 3 and table 1.4), or 57.2 percent of all streamgages. The modified trend analyses resulted in 64 statistically significant trends (49 upward, 15 downward) for the USGS streamgages (compared with 54 upward and 17 downward trends without adjusting for STP) and 22 upward trends (unchanged) for the ECCC streamgages. This reflects an overall reduction of 7.5 percent in the total number of significant annual trends (93 to 86 ) when considering STP, which is less than the $p$-value of 0.10 used for significance testing.

Significant STP in seasonal streamflow was documented for 126 out of 412 USGS streamgage seasons and 19 out of 140 ECCC streamgage seasons (table 3 and table 1.4), or 26.3 percent of all seasons. Significant STP was most prevalent for October-December for USGS and ECCC streamgages (56.3 and 17.1 percent of streamgages, respectively) and least prevalent for April-June for USGS and ECCC streamgages (10.7 and 5.7 percent of streamgages, respectively). The modified trend analyses for the USGS streamgages resulted in 185 statistically significant seasonal trends (148 upward, 37 downward), compared with 156 upward and 48 downward trends without adjusting for STP. For the ECCC streamgages, the modified trend analyses resulted in 64 statistically significant seasonal trends (63 upward, 1 downward), compared with 64 upward and 1 downward trends without adjusting for STP. This reflects an overall reduction of 7.4 percent in the total number of significant seasonal trends (269 to 249) when considering STP, which is less than the $p$-value of 0.10 used for significance testing. Thus, overall effects of serial correlation on trend analyses for annual and seasonal streamflow data can be considered relatively minor.

Statistically significant STP was measured for all waterbudget components and within all the drainage basins (all but 6 of 29 parameters considered in table 1.5). The presence of STP in the water-budget components had substantial effects on trend results, except for the annual total of monthly runoff, which indicated no difference in the number of significant trends. Overall, consideration of STP reduced the total number of statistically significant trends from 15 to 8; thus, trend analyses for water-budget components are substantially affected by serial correlation. It is noteworthy that statistically significant trends were indicated for the annual precipitation data from PRISM for all drainage basins considered except Lake Superior (table 1.3); however, significant trends for the annual total of monthly overlake precipitation (table 1.5) were indicated only for the Lake Saint Clair and Lake Ontario drainage basins. A plausible explanation is that two datasets were considered in these analyses, because the PRISM data (table 1.3) excluded precipitation in Canada. 
Table 3. Summary of results from comparison of standard and modified Mann-Kendall tests for streamflow data.

[SS, statistically significant at probability value of less than or equal to 0.10; MKT, standard Mann-Kendall test (Helsel and Hirsch, 2002); STP, short-term persistence from the Ljung-Box test (Ljung and Box, 1978); Mod MKT, modified Mann-Kendall test (Bronaugh and Werner, 2013); USGS, U.S. Geological Survey; ECCC, Environment and Climate Change Canada; NC, no change]

\begin{tabular}{|c|c|c|c|c|c|c|c|c|c|c|c|c|}
\hline \multirow{2}{*}{ Data source } & \multirow{2}{*}{$\begin{array}{c}\text { Number } \\
\text { of } \\
\text { streamgages }\end{array}$} & \multicolumn{3}{|c|}{$\begin{array}{c}\text { Number of streamgages with SS } \\
\text { trends from MKT }\end{array}$} & \multicolumn{2}{|c|}{ Streamgages with STP } & \multicolumn{3}{|c|}{$\begin{array}{c}\text { Number of streamgages with SS } \\
\text { trends from Mod MKT }\end{array}$} & \multicolumn{3}{|c|}{ Percent change $^{a}$} \\
\hline & & Upward & Downward & Total & Number & Percentage & Upward & Downward & Total & Upward & Downward & Total \\
\hline \multicolumn{13}{|c|}{ Summary for annual data } \\
\hline USGS streamgages $^{\mathrm{b}}$ & 103 & 54 & 17 & 71 & 73 & 70.9 & 49 & 15 & 64 & -9.3 & -11.8 & -9.9 \\
\hline 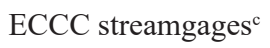 & 35 & 22 & 0 & 22 & 6 & 17.1 & 22 & 0 & 22 & 0.0 & $\mathrm{NC}$ & 0.0 \\
\hline All streamgages & 138 & 76 & 17 & 93 & 79 & 57.2 & 71 & 15 & 86 & -6.6 & -11.8 & -7.5 \\
\hline \multicolumn{13}{|c|}{ Summary for October-December data } \\
\hline USGS streamgages $^{\mathrm{b}}$ & 103 & 45 & 8 & 53 & 58 & 56.3 & 41 & 6 & 47 & -8.9 & -25.0 & -11.3 \\
\hline ECCC streamgages $^{c}$ & 35 & 27 & 0 & 27 & 6 & 17.1 & 27 & 0 & 27 & 0.0 & $\mathrm{NC}$ & 0.0 \\
\hline All streamgages & 138 & 72 & 8 & 80 & 64 & 46.4 & 68 & 6 & 74 & -5.6 & -25.0 & -7.5 \\
\hline \multicolumn{13}{|c|}{ Summary for January-March data } \\
\hline USGS streamgages $^{\mathrm{b}}$ & 103 & 27 & 5 & 32 & 31 & 30.1 & 24 & 3 & 27 & -11.1 & -40.0 & -15.6 \\
\hline ECCC streamgages $^{c}$ & 35 & 18 & 0 & 18 & 5 & 14.3 & 17 & 0 & 17 & -5.6 & $\mathrm{NC}$ & -5.6 \\
\hline All streamgages & 138 & 45 & 5 & 50 & 36 & 26.1 & 41 & 3 & 44 & -8.9 & -40.0 & -12.0 \\
\hline \multicolumn{13}{|c|}{ Summary for April-June data } \\
\hline USGS streamgages $^{\mathrm{b}}$ & 103 & 33 & 17 & 50 & 11 & 10.7 & 32 & 16 & 48 & -3.0 & -5.9 & -4.0 \\
\hline ECCC streamgages $^{c}$ & 35 & 2 & 1 & 3 & 2 & 5.7 & 2 & 1 & 3 & 0.0 & 0.0 & 0.0 \\
\hline All streamgages & 138 & 35 & 18 & 53 & 13 & 9.4 & 34 & 17 & 51 & -2.9 & -5.6 & -3.8 \\
\hline \multicolumn{13}{|c|}{ Summary for July-September data } \\
\hline USGS streamgages $^{\mathrm{b}}$ & 103 & 51 & 18 & 69 & 26 & 25.2 & 51 & 12 & 63 & 0.0 & -33.3 & -8.7 \\
\hline 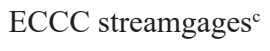 & 35 & 17 & 0 & 17 & 6 & 17.1 & 17 & 0 & 17 & 0.0 & $\mathrm{NC}$ & 0.0 \\
\hline All streamgages & 138 & 68 & 18 & 86 & 32 & 23.2 & 68 & 12 & 80 & 0.0 & -33.3 & -7.0 \\
\hline \multicolumn{13}{|c|}{ Summary for all seasonal data } \\
\hline USGS streamgages $^{\mathrm{b}}$ & $412^{\mathrm{d}}$ & 156 & 48 & 204 & 126 & 30.6 & 148 & 37 & 185 & -5.1 & -22.9 & -9.3 \\
\hline ECCC streamgages $^{c}$ & $140^{\mathrm{d}}$ & 64 & 1 & 65 & 19 & 13.6 & 63 & 1 & 64 & -1.6 & $\mathrm{NC}$ & -1.5 \\
\hline All streamgages & $552^{\mathrm{d}}$ & 220 & 49 & 269 & 145 & 26.3 & 211 & 38 & 249 & -4.1 & -22.4 & -7.4 \\
\hline
\end{tabular}

aPercent change in number of streamgages with SS trends between MKT and Mod MKT, calculated as ([Mod HMKT minus MKT]/MKT) times 100.

${ }^{b}$ U.S. Geological Survey (2016).

cEnvironment and Climate Change Canada (2016).

${ }^{\mathrm{d}}$ Total number of streamgage seasons, computed as number of streamgages times 4 . 
Potential effects of serial correlation on trend analyses were examined by evaluating the presence of STP in time-series datasets. Effects of STP were considered inconsequential for climate data and relatively minor for streamflow data; however, the presence of STP in water-budget components had more substantial effects on trend analyses.

\section{Summary}

Water levels in the Great Lakes fluctuate substantially because of complex interactions among inputs (precipitation and streamflow), outputs (evaporation and outflow), and other factors. This report by the U.S. Geological Survey in cooperation with the Great Lakes Restoration Initiative was completed to describe trends in climate, streamflow, lake levels, and major water-budget components within the Great Lakes Basin for water years (WYs) 1960-2015 (study period). Resulting trends are applicable only to the study period and should not be considered indicative of longer-term trends.

Analyses of climate trends used monthly data from the Parameter-elevation Regressions on Independent Slopes Model, which are available only for the United States. Monthly Parameter-elevation Regressions on Independent Slopes Model data were aggregated to obtain annual and seasonal datasets of monthly means for total precipitation, minimum air temperature $\left(T_{\min }\right)$, and maximum air temperature $\left(T_{\max }\right)$. Trend tests for 2.5 -arc-minute gridded data for total precipitation, $T_{\min }$, and $T_{\max }$ were completed for the annual and seasonal time series. Statistical significance for all time-trend tests (climate, streamflow, and lake levels) was determined using the nonparametric Mann-Kendall test for probability values less than or equal to 0.10 . Trend analyses were completed without adjustments for serial correlation; however, a modified Mann-Kendall test was subsequently used to examine potential effects of short-term persistence in timeseries data. Effects of short-term persistence were considered inconsequential for climate data and relatively minor for streamflow data; however, the presence of short-term persistence in water-budget components had more substantial effects on trend analyses.

For the U.S. land part of the Great Lakes Basin, a statistically significant upward trend in total precipitation is driven by substantial increases in precipitation during the 1960s through the early 1970s and since about 2000. Except for the contributing drainage area for Lake Superior, the individual lake subbasins have similar upward trends driven by substantial increases in precipitation during the same general periods.

For the U.S. land part of the Great Lakes Basin, a statistically significant upward trend in $T_{\min }$ is indicated; however, the trend for $T_{\max }$ is not significant and is in effect neutral. Annual trends in $T_{\min }$ and $T_{\max }$ for the individual lake subbasins are generally similar to those for the Great Lakes
Basin. An upward trend in $T_{\min }$ is indicated for the Lake Superior subbasin, but the probability value of 0.1134 is slightly greater than the significance criterion of 0.10 . Upward trends in $T_{\min }$ are statistically significant for the other four individual lake subbasins. Trends in $T_{\max }$ are nonsignificant for all five of the individual lake subbasins.

Of 103 U.S. Geological Survey streamgages analyzed for streamflow trends, 71 had significant annual trends (54 upward and 17 downward). Of these, 70 streamgages had at least one season with a significant trend that matched the annual trend direction. Significant upward seasonal trends were most common for October-December and July-September, and significant downward seasonal trends were most common for April-June and July-September.

Of 35 Environment and Climate Change Canada streamgages analyzed, 22 had significant upward trends in annual streamflow, and all but 1 of these 22 had at least one season with a significant upward trend. None of the Environment and Climate Change Canada streamgages had significant downward annual trends, and there was only one significant downward seasonal trend. Significant upward seasonal trends were most common for October-December, followed by January-March and July-September. April-June had only two significant upward seasonal trends, and the only significant downward seasonal trend.

Among all 138 U.S. Geological Survey and Environment and Climate Change Canada streamgages, July-September was the predominant season for minimum streamflow. The predominant seasons for maximum streamflow were January-March and April-June. Significant upward seasonal trends in seasons with maximum streamflow were not necessarily strong drivers of annual trends.

Downward trends in annual streamflow are concentrated northwest of Lake Michigan, which is consistent with spatially distributed downward trends in annual precipitation and neutral to upward trends in $T_{\text {min }}$. Upward trends in annual streamflow are concentrated east of Lake Michigan, which is consistent with spatially distributed upward trends in annual precipitation. Upward trends in annual $T_{\min }$ in this area apparently are insufficient to offset the upward trends in annual precipitation, relative to effects on annual streamflow.

Trends in lake levels and several major water-budget components affecting lake levels were analyzed for WYs 1960-2015. A significant downward trend in lake level for Lake Superior is driven primarily by a prolonged period of low lake levels during about WYs 1998-2014. A significant downward trend in outflow from Lake Superior corresponds to the lake-level trend, because lake outflow is greatly affected by lake level. A significant downward trend in runoff from the contributing drainage area also is indicated, which is consistent with numerous streamgages northwest of Lake Michigan with significant downward trends in annual streamflow. A significant upward trend in annual overlake evaporation also is indicated, which is consistent with the spatially distributed upward trends in annual $T_{\min }$. 
Similar to Lake Superior, Lakes Michigan and Huron, Lake Saint Clair, and Lake Erie all have a prolonged period of low lake levels during about WYs 1998-2014; however, a significant downward trend for WYs 1960-2015 is indicated only for Lakes Michigan and Huron. All these lakes also have a period of low lake levels before about 1968, when minimum lake levels were lower than during WYs 1998-2014. The pattern of pre-1968 low lake levels is carried downstream into Lake Ontario; however, lake levels for Lake Ontario during WYs 1998-2014 are near the mean. The significant downward trend of outflow from Lake Superior is carried downstream into Lakes Michigan and Huron; however, trends in outflow from the next three lakes downstream (Lakes Saint Clair, Erie, and Ontario) are offset by increased precipitation and runoff and are not significant.

The sum of overlake precipitation and runoff from the contributing drainage area for each of the Great Lakes, less overlake evaporation, composes a variable called net basin supply (NBS). A significant downward trend in NBS is indicated for Lake Superior, which is consistent with significant trends for individual components of runoff (downward) and evaporation (upward) that contributed to a significant downward trend for lake outflow. Statistically significant upward trends in NBS for Lake Saint Clair and Lake Ontario offset the downward trend for Lake Superior and combine with nonsignificant increasing NBS trends for Lakes Michigan and Huron and Lake Erie to produce a neutral NBS trend for the basin.

A predictable pattern in monthly mean lake levels is noted for Lake Superior; the minimum for each year usually occurs during or near March, and the maximum most commonly occurs during or near September or October. When an October lake level is in a period of substantial decline, potential for an ensuing short-term period of below-mean lake levels is enhanced. Downstream from Lake Superior, monthly lake levels have sawtooth patterns that somewhat resemble those for Lake Superior but with decreased predictability in timing.

The spatial distribution of trends in climatic data for WYs 1960-2015 for the U.S. part of the Great Lakes Basin (land only) clearly indicates (1) generally ubiquitous upward trends in $T_{\min }$ and (2) a sharp transition from neutral or downward trends in precipitation northwest of Lake Michigan to generally upward trends east of Lake Michigan. The downward precipitation trends northwest of Lake Michigan combine with the upward trends in $T_{\min }$ to drive downward trends in runoff for Lake Superior. In combination, the precipitation, runoff, and evaporation trends drive statistically significant downward trends in NBS and lake outflow for Lake Superior, which contributes to a significant downward trend in lake outflow for Lakes Michigan and Huron, despite a neutral NBS trend. Trends in NBS are neutral to mildly upward for the remainder of the downstream lakes and collectively combine to offset the effect of the downward trend in outflow from Lakes Michigan and Huron, resulting in neutral outflow trends for the downstream lakes.
Although evaporation is clearly an important factor for Great Lakes water budgets and trends, the importance of precipitation and runoff is not to be dismissed because, without the offsetting effect of the upward trends for these variables for the downstream lakes, the prolonged trend of low NBS and outflow for Lake Superior during WYs 1998-2014 would have had a considerable effect for the downstream lakes. The importance of precipitation and runoff is well illustrated by the low lake levels in the downstream lakes during the 1960s, when consecutive years of low NBS existed, despite evaporation in the downstream lakes that generally was smaller than during WYs 1998-2014.

\section{References Cited}

Anderson, M.T., and Norton, P.A., 2013, Long-term trends in mean annual streamflow in the United States for the period 1960 to 2012: American Geophysical Union 2013 Fall Meeting, Abstract H52B-02, December 9-13, 2013, San Francisco, Calif., accessed August 16, 2017, at http://abstractsearch.agu.org/meetings/2013/FM/H52B-02. html.

Bayazit, M., 2015, Nonstationarity of hydrological records and recent trends in trend analysis-A state-of-the-art review: Environmental Processes, v. 2, no. 3, p. 527-542. [Also available at https://doi.org/10.1007/s40710-015-0081-7.]

Blain, G.C., 2013, The Mann-Kendall test-The need to consider the interaction between serial correlation and trend: Acta Scientiarum, Agronomy, v. 35, no. 4, p. 393-402. [Also available at https://doi.org/10.4025/actasciagron.v35i4.16006.]

Blain, G.C., 2014, Removing the influence of the serial correlation on the Mann-Kendall test: Revista Brasileira de Meteorologia, v. 29, no. 2, p. 161-170. [Also available at https://doi.org/10.1590/S0102-77862014000200002.]

Bronaugh, D., and Werner, A., 2013, zyp-Zhang + YuePilon trends package - $\mathrm{R}$ package version $0.10-1$ : CRAN web page, accessed March 13, 2018, at https:/CRAN.R-project.org/package=zyp.

Cleveland, W.S., and Devlin, S.J., 1988, Locally-weighted regression-An approach to regression analysis by local fitting: Journal of the American Statistical Association, v. 83 , no. 403 , p. 596-610. [Also available at https://doi.org/10.1080/01621459.1988.10478639.]

Cohn, T.A., and Lins, H.F., 2005, Nature's style-Naturally trendy: Geophysical Research Letters, v. 32, no. 23, 5 p. [Also available at https://doi.org/10.1029/2005GL024476.] 
Coordinating Committee on Great Lakes Basic Hydraulic and Hydrologic Data, 1992, IGLD 1985Brochure on the International Great Lakes Datum 1985: accessed September 28, 2018, at http://www. greatlakescc.org/wp36/wp-content/uploads/2017/01/ InternationalGreatLakesDatumof1985Brochure.pdf.

Daly, C., Neilson, R.P., and Phillips, D.L., 1994, A statistical-topographic model for mapping climatological precipitation over mountainous terrain: Journal of Applied Meteorology, v. 33, no. 2, p. 140-158. [Also available at https://doi.org/10.1175/1520-0450(1994)033\%3C0140:AST MFM\%3E2.0.CO;2.]

Daly, C., Gibson, W.P., Taylor, G.H., Johnson, G.L., and Pasteris, P., 2002, A knowledge-based approach to the statistical mapping of climate: Climate Research, v. 22, no. 2, p. 99-113. [Also available at https://doi.org/10.3354/cr022099.]

Daly, C., Halbleib, M., Smith, J.I., Gibson, W.P., Doggett, M.K., Taylor, G.H., Curtis, J., and Pasteris, P.P., 2008, Physiographically sensitive mapping of climatological temperature and precipitation across the conterminous United States: International Journal of Climatology, v. 28, no. 15, p. 2031-2064. [Also available at https://doi.org/10.1002/joc.1688.]

Dudley, R.W., Hodgkins, G.A., McHale, M.R., Kolian, M.J., and Renard, B., 2017, Trends in snowmelt-related streamflow timing in the conterminous United States: Journal of Hydrology [Amsterdam], v. 547, p. 208-221. [Also available at https://doi.org/10.1016/j.jhydrol.2017.01.051.]

Environment and Climate Change Canada, 2016, National water data archive-HYDAT database: Government of Canada web page, accessed November 23, 2016, at https://www.canada.ca/en/environment-climate-change/ services/water-overview/quantity/monitoring/survey/dataproducts-services/national-archive-hydat.html.

Gibson, W., Daly, C., Kittel, T., Nychka, D., Johns, C., Rosebloom, N., McNab, A., and Taylor, G., 2002, Development of a 103-year high-resolution climate data set for the conterminous United States: AMS Conference on Applied Climatology, Portland, Oreg., May 13-16, 2002, p. 181-183.

Hamed, K.H., 2008, Trend detection in hydrologic data-The Mann-Kendall trend test under the scaling hypothesis: Journal of Hydrology [Amsterdam], v. 349, no. 3-4, p. 350-363. [Also available at https://doi.org/10.1016/j.jhydrol.2007.11.009.]

Helsel, D.R., and Hirsch, R.M., 2002. Statistical methods in water resources: U.S. Geological Survey Techniques of Water-Resources Investigations, book 4, chapter A3, 522 p., accessed June 2018 at https://pubs.usgs.gov/twri/twri4a3/.
Hodgkins, G.A., and Dudley, R.W., 2011, Historical summer base flow and stormflow trends for New England rivers: Water Resources Research, v. 47, no. 7, W07528. [Also available at https://doi.org/10.1029/2010WR009109.]

Hodgkins, G.A., Dudley, R.W., and Aichele, S.S., 2007, Historical changes in precipitation and streamflow in the U.S. Great Lakes Basin, 1915-2004: U.S. Geological Survey Scientific Investigations Report 2007-5118, 31 p. [Also available at https://pubs.usgs.gov/sir/2007/5118/.]

Hodgkins, G.A., Dudley, R.W., Nielsen, M.G., Renard, B., and Qi, S.L., 2017, Groundwater-level trends in the U.S. glacial aquifer system 1964-2013: Journal of Hydrology [Amsterdam], v. 553, p. 289-303. [Also available at https://doi.org/10.1016/j.jhydrol.2017.07.055.]

Hunter, T.S., Clites, A.H., Campbell, K.B., and Gronewold, A.D., 2015, Development and application of a North American Great Lakes hydrometeorological database - Part I-Precipitation, evaporation, runoff, and air temperature: Journal of Great Lakes Research, v. 41, no. 1, p. 65-77. [Also available at https://doi.org/10.1016/j.jglr.2014.12.006.]

International Joint Commission, 1999, Protection of the waters of the Great Lakes - Interim report to the Governments of Canada and the United States: International Joint Commission, Ottawa, Ontario, and Washington, D.C., 40 p., accessed August 3, 2017, at https://scholar.uwindsor.ca/ijcarchive/547/.

Kendall, M.G., 1938, A new measure of rank correlation: Biometrika, v. 30, no. 1-2, p. 81-93. [Also available at https://doi.org/10.1093/biomet/30.1-2.81.]

Lenters, J.D., 2004, Trends in Lake Superior water budget since 1948-A weakening seasonal cycle: Journal of Great Lakes Research, v. 30, p. 20-40. [Also available at https://doi.org/10.1016/S0380-1330(04)70375-5.]

Lenters, J.D., Anderton, J.B., Blanken, P.D., Spence, C., and Suyker, A.E., 2013, Assessing the impacts of climate variability and change on Great Lakes evaporation, in Brown, D., Bidwell, D., and Briley, L., eds., 2011 Project Reports: Great Lakes Integrated Sciences and Assessments (GLISA) Center, accessed November 10, 2016, at http://glisaclimate.org/media/GLISA_Lake_Evaporation. pdf.

Ljung, G.M., and Box, G.E.P., 1978, On a measure of lack of fit in time series models: Biometrika, v. 65, no. 2, p. 297-303. [Also available at https://doi.org/10.1093/biomet/65.2.297.]

Neff, B.P., and Nicholas, J.R., 2005, Uncertainty in the Great Lakes water balance, 2005: U.S. Geological Survey Scientific Investigations Report 2004-5100, 42 p., accessed June 26, 2017, at https://pubs.water.usgs.gov/sir2004-5100/. 
Norton, P.A., Anderson, M.T., and Stamm, J.F., 2014, Trends in annual, seasonal, and monthly streamflow characteristics at 227 streamgages in the Missouri River watershed, water years 1960-2011: U.S. Geological Survey Scientific Investigations Report 2014-5053, 128 p., accessed December 12, 2016, at https://pubs.usgs.gov/sir/2014/5053/.

Obenour, D., Bartani, I., Gronewold, D., Stow, C., and Scavia, D., 2016, 2016 Lake Erie harmful algal bloom (HAB) forecast: National Oceanic and Atmospheric Administration Great Lakes Environmental Research Laboratory, accessed November 10, 2016, at http://graham.umich.edu/scavia/wp-content/ uploads/2016/07/2016-LakeErieBloomForecastRelease.pdf.

Ohio Division of Water Resources, 2017, Great Lakes Compact Program: Ohio Department of Natural Resources web page, accessed October 13, 2017, at http://water. ohiodnr.gov/water-use-planning/great-lakes-compact\#PUB.

Önöz, B., and Bayazit, M., 2012, Block bootstrap for Mann-Kendall trend test of serially dependent data: Hydrological Processes, v. 26, no. 23, p. 3552-3560. [Also available at https://doi.org/10.1002/hyp.8438.]

R Core Team, 2017, R—A language and environment for statistical computing: Vienna, Austria, R Foundation for Statistical Computing, ver. 3.5.1, accessed June 2017 at https://www.R-project.org/.

Shiklomanov, I.A., 1993, World fresh water resources, in Gleick, P.H., ed., Water in crisis-A guide to the world's fresh water resources: New York, Oxford University Press, p. 13-24.

Smith, J.P., Hunter, T.S., Clites, A.H., Stow, C.A., Slawecki, T., Muhr, G.C., and Gronewold, A.D., 2016, An expandable web-based platform for visually analyzing basin-scale hydro-climate time series data: Environmental Modelling \& Software, v. 78, p. 97-105. [Also available at https://doi.org/10.1016/j.envsoft.2015.12.005.]
Thornton, P.E., Thornton, M.M., Mayer, B.W., Wei, Y., Devarakonda, R., Vose, R.S., and Cook, R.B., 2016, Daymet-Daily surface weather data on a 1-km grid for North America, version 3: Oak Ridge, Tenn., Oak Ridge National Laboratory Distributed Active Archive Center, accessed January 4, 2017, at https://doi.org/10.3334/ORNLDAAC/1328.

U.S. Army Corps of Engineers, 2017, Long term average, maximum, and minimum Great Lakes water levels: U.S. Army Corps of Engineers web page, accessed September 12, 2017, at https://www.lre.usace.army.mil/ Missions/Great-Lakes-Information/Great-Lakes-WaterLevels/Historical-Data/.

U.S. Geological Survey, 2014, Great Lakes restoration success through science-U.S. Geological Survey accomplishments 2010 through 2013: U.S. Geological Survey Circular 1404, 58 p. [Also available at https://doi.org/10.3133/cir1404.]

U.S. Geological Survey, 2016, USGS water data for the Nation: U.S. Geological Survey National Water Information System database, accessed November 23, 2016, at https://doi.org/10.5066/F7P55KJN.

Wang, X.L., and Swail, V.R., 2001, Changes in extreme wave heights in northern hemisphere oceans and related atmospheric circulation regimes: Journal of Climate, v. 14 , no. 10, p. 2204-2221. [Also available at https://doi.org/10.1175/1520-0442(2001)014\%3C2204:COE WHI\%3E2.0.CO;2.]

Wilks, D.S., 2011, Statistical methods in atmospheric sciences 3d ed.: Waltham, Mass., Oxford, Academic Press, 661 p.

Yue, S., and Wang, C.Y., 2002, Applicability of prewhitening to eliminate the influence of serial correlation on the Mann-Kendall test: Water Resources Research, v. 38, no. 6, p. 4-1 to 4-7. [Also available at https://doi.org/10.1029/2001WR000861.] 


\section{Appendix}

Streamflow records for a total of 138 streamgages (103 U.S. Geological Survey streamgages and 35 Environment and Climate Change Canada streamgages) (fig. 2) in the Great Lakes Basin were analyzed for trends in annual, seasonal, and monthly streamflow. Selected site information and monthly mean streamflow values for these streamgages are presented in table 1.1 (Microsoft ${ }^{\circledR}$ Excel format). Trends in annual and seasonal streamflow for the 138 streamgages are presented in table 1.2 (Microsoft ${ }^{\circledR}$ Excel format).

Potential effects of serial correlation in time-series data on statistical significance in trend analyses were evaluated using a modified Mann-Kendall test, as described in the section "Implications Regarding Serial Correlation in Trend Analyses." Results from the modified Mann-Kendall test are compared against results from the standard Mann-Kendall test in tables 1.3 through 1.5 (Microsoft ${ }^{\circledR}$ Excel format).
Graphs of annual and seasonal streamflow trends for the 138 streamgages considered are presented in figures 1.1 through 1.138. Graphs for the U.S. Geological Survey streamgages are presented in figures 1.1 through 1.103, and graphs for the Environment and Climate Change Canada streamgages are presented in figures 1.104 through 1.138. A total of five graphs are presented for each streamgage. Graph $A$ shows the annual mean streamflow for water years 1960-2015 and annual streamflow trends. Graphs $B-E$ show the seasonal mean streamflows for October-December, January-March, April-June, and July-September, respectively. On the graphs, a solid green line indicates the locally weighted regression smooth line for a significant trend (probability value less than or equal to 0.10 ), and a solid gray line indicates the locally weighted regression smooth line for a nonsignificant trend (probability value greater than 0.10 ). A dashed gray line indicates the water year 1960-2015 mean streamflow. 

For more information about this publication, contact: Director, USGS Dakota Water Science Center 821 East Interstate Avenue, Bismarck, ND 58503 1608 Mountain View Road, Rapid City, SD 57702 605-394-3200

For additional information, visit: https://www.usgs.gov/centers/dakota-water

Publishing support provided by the Rolla and Sacramento Publishing Service Centers 
